Oyster Model Inventory: Identifying Critical Data and Modeling Approaches to Support Restoration of Oyster Reefs in Coastal U.S. Gulf of Mexico Waters

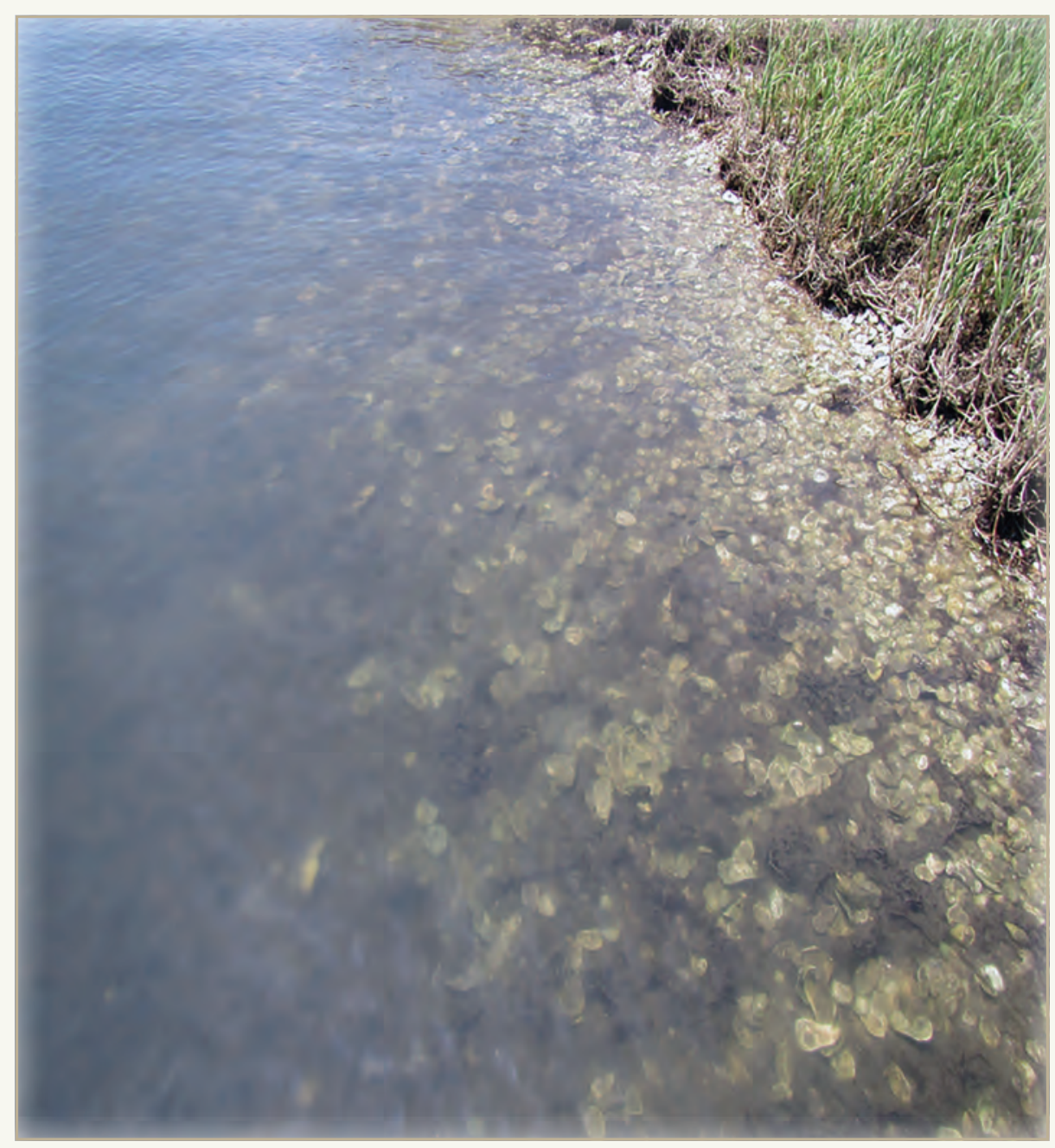

Open-File Report 2021-1063 
Cover. Oyster reef in shallow waters of Terrebonne Bay, Louisiana. Photograph by Megan La Peyre, U.S. Geological Survey. 


\section{Oyster Model Inventory: Identifying Critical Data and Modeling Approaches to Support Restoration of Oyster Reefs in Coastal U.S. Gulf of Mexico Waters}

By Megan K. La Peyre, Danielle A. Marshall, and Shaye E. Sable

Open-File Report 2021-1063 


\section{U.S. Geological Survey, Reston, Virginia: 2021}

For more information on the USGS - the Federal source for science about the Earth, its natural and living resources, natural hazards, and the environment-visit https://www.usgs.gov or call 1-888-ASK-USGS.

For an overview of USGS information products, including maps, imagery, and publications, visit https://store.usgs.gov.

Any use of trade, firm, or product names is for descriptive purposes only and does not imply endorsement by the U.S. Government.

Although this information product, for the most part, is in the public domain, it also may contain copyrighted materials as noted in the text. Permission to reproduce copyrighted items must be secured from the copyright owner.

Suggested citation:

La Peyre, M.K., Marshall, D.A., and Sable, S.E., 2021, Oyster model inventory: Identifying critical data and modeling approaches to support restoration of oyster reefs in coastal U.S. Gulf of Mexico waters: U.S. Geological Survey Open-File Report 2021-1063, 40 p., https://doi.org/10.3133/ofr20211063.

ISSN 2331-1258 (online) 


\section{Acknowledgments}

The development of this report, including the spreadsheet and map files, was supported by a grant from The Pew Charitable Trusts. The views expressed do not necessarily reflect the views of The Pew Charitable Trusts. We thank Lauren Swam, Louisiana State University Agricultural Center, and Zachary Wallen, Dynamic Solutions, LLC, for creating the maps produced for this report. The authors thank Dr. Tom Soniat, University of New Orleans, Dr. Scott Milroy, University of Southern Mississippi, and Brady Carter, Louisiana Department of Wildlife and Fisheries for critical review of an earlier versions of this work. The authors thank Dr. Simeon Yurek, U.S. Geological Survey, for critical comments and review of an earlier version of this work. 



\section{Contents}

Acknowledgments …........................................................................................................................

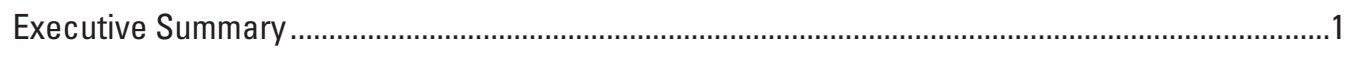

Introduction

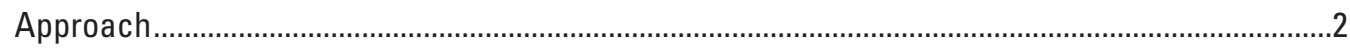

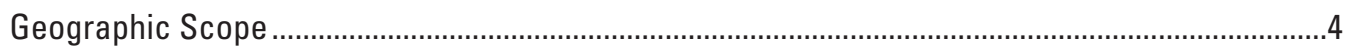

Eastern Oyster (Crassostrea virginica): Environmental Drivers .......................................................

Data, Models, and Approaches (Inventory) …….....................................................................

Water-Quality, Ecological, and Physical Data .........................................................................

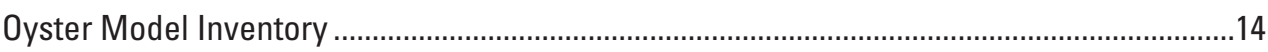

Approach 1: Geospatial Habitat Suitability Index......................................................17

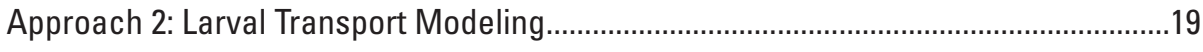

Approach 3: On-Reef Oyster Growth, Mortality, and Reproduction Modeling................22

Approach 4: Metapopulation Approach (Coupled Larval Transport and On-Reef

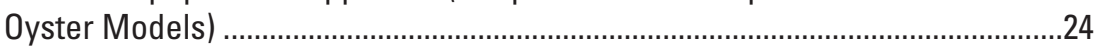

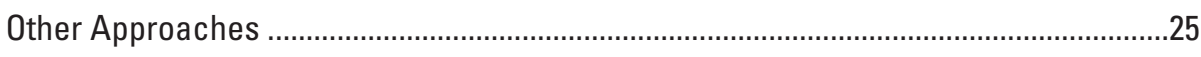

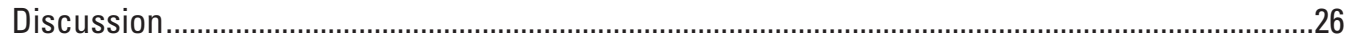

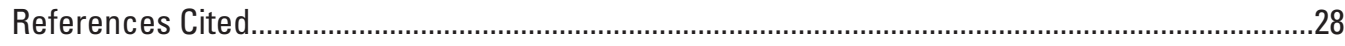

Appendix 1. Discrete Water-Quality Data Sources ................................................................40

Appendix 2. Modeled Water-Quality and Physical Data Sources ...............................................40

Appendix 3. Oyster Model Inventory ......................................................................................

\section{Figures}

1. Diagram showing conceptual model of data and model needs for informing eastern oyster restoration planning using a metapopulation approach...

2. Map showing U.S. Gulf of Mexico estuaries and coastal areas included in

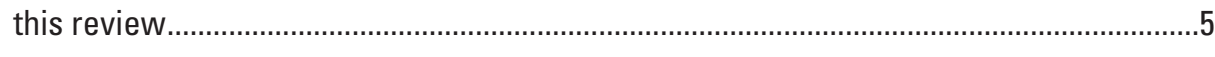

3. Diagram showing the oyster life cycle, on reef drivers, and larval drivers ......................9

4. Map showing identification, by estuary, of available water-quality, physical, and

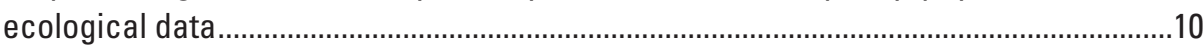

5. Maps showing discrete and modeled ecological and water-quality data from publicly available sources for each estuary ..................................................................11

6. Maps showing discrete and modeled physical data availability for each estuary .........12

7. Maps showing example of two estuaries with long-term data records available ..........13

8. Diagram showing drivers and outputs of models capturing larval transport, on-reef population dynamics, and metapopulation models that simulate the entire oyster life cycle, coupling larval and on-reef population dynamics models ....................15

9. Map showing oyster models by approach constructed in each estuary across the waters of the U.S. Gulf of Mexico ..........................................................................16

10. Maps showing oyster Habitat Suitability Index models calibrated and (or) validated by estuary across the U.S. coastal waters of the Gulf of Mexico..

11. Maps showing larval transport models developed, calibrated, and validated in Gulf of Mexico estuaries. 
12. Maps showing models representing and evaluating on-reef oyster population vital rates or processes, such as filtration, growth, mortality, and reproduction, with changing environmental and biological drivers developed, calibrated, and validated for Gulf of Mexico estuaries

\section{Tables}

1. Ecological, water-quality, and physical habitat and connectivity drivers for oyster suitability, larval transport, and on-reef models, including variable and units commonly used

2. Summary of the four major modeling approaches currently available for informing eastern oyster site selection for restoration and management

\section{Conversion Factors}

International System of Units to U.S. customary units

\begin{tabular}{lcl}
\hline \multicolumn{1}{c}{ Multiply } & By & \multicolumn{1}{c}{ To obtain } \\
\hline centimeter $(\mathrm{cm})$ & Length & \\
millimeter $(\mathrm{mm})$ & 0.3937 & inch (in.) \\
meter $(\mathrm{m})$ & 0.03937 & inch (in.) \\
\hline \multicolumn{3}{c}{ Area } \\
\hline square meter $\left(\mathrm{m}^{2}\right)$ & 3.281 & foot (ft) \\
hectare $($ ha) & 0.0002471 & acre \\
square hectometer $\left(\mathrm{hm}^{2}\right)$ & 2.471 & acre \\
square kilometer $\left(\mathrm{km}^{2}\right)$ & 2.471 & acre \\
square meter $\left(\mathrm{m}^{2}\right)$ & 247.1 & acre \\
hectare $($ ha) & 10.76 & square foot $\left(\mathrm{ft}^{2}\right)$ \\
square kilometer $\left(\mathrm{km}^{2}\right)$ & 0.003861 & square mile $\left(\mathrm{mi}^{2}\right)$ \\
& 0.3861 & square mile $\left(\mathrm{mi}^{2}\right)$ \\
\hline centimeter per second $(\mathrm{m} / \mathrm{s})$ & Flow rate & \\
\hline
\end{tabular}

Temperature in degrees Celsius $\left({ }^{\circ} \mathrm{C}\right)$ may be converted to degrees Fahrenheit $\left({ }^{\circ} \mathrm{F}\right)$ as follows ${ }^{\circ} \mathrm{F}=\left(1.8 \times{ }^{\circ} \mathrm{C}\right)+32$. 


\section{Datum}

Horizontal coordinate information is referenced to the North American Datum of 1983 (NAD 83).

\section{Supplemental Information}

Concentrations of chemical constituents in water are given in either milligrams per liter (mg/L) or micrograms per liter ( $\mu \mathrm{g} / \mathrm{L})$.

\section{Abbreviations}

\begin{tabular}{|c|c|}
\hline ADCIRC & Advanced Circulation Model \\
\hline ADCNR & Alabama Department of Conservation and Natural Resources \\
\hline ADEM & Alabama Department of Environmental Management \\
\hline AdH & Adaptive Hydrodynamics Model \\
\hline ARCOS & Alabama's Real-Time Coastal Observing System \\
\hline CBP & Chesapeake Bay Program \\
\hline CERP & Comprehensive Everglades Restoration Program \\
\hline $\mathrm{CH} 3 \mathrm{D}$ & curvilinear-grid 3D model \\
\hline CIMS & CPRA Coastal Information Management System \\
\hline CMAP & NOAA Council Monitoring and Assessment Program \\
\hline COAWST & Coupled-Ocean-Atmosphere-Wave-Sediment Transport \\
\hline CPRA & Coastal Protection and Restoration Authority \\
\hline CRMS & Coastal Reference Monitoring System \\
\hline DEB & Dynamic Energy Budget \\
\hline D-FLOW & Delft-FLOW hydrodynamic model \\
\hline DO & dissolved oxygen \\
\hline D-WAO & Delft Water Quality model \\
\hline ECOM & Estuarine Coastal Ocean Model \\
\hline EFDC & Environmental Fluid Dynamics Code \\
\hline EPA & U.S. Environmental Protection Agency \\
\hline ES & Ecosystem Service (index) \\
\hline FDEP & Florida Department of Environmental Protection \\
\hline FL WQMP & Florida Water Quality Monitoring Project \\
\hline FTLOADDS & Flow and Transport in a Linked Overland/Aquifer Density Dependent System \\
\hline FVCOM & Finite Volume Community Ocean Model \\
\hline FWCC & Florida Fish and Wildlife Conservation Commission \\
\hline GOMA & Gulf of Mexico Alliance \\
\hline GRIIDC & Gulf of Mexico Research Initiative \\
\hline $\mathrm{HSI}$ & Habitat Suitability Index \\
\hline LA MP ICM & Louisiana Master Plan Integrated Compartment Model \\
\hline
\end{tabular}




$\begin{array}{ll}\text { LCRA } & \text { Lower Colorado River Authority } \\ \text { LDEO } & \text { Louisiana Department of Environmental Quality } \\ \text { LDWF } & \text { Louisiana Department of Wildlife and Fisheries } \\ \text { LTRANS } & \text { Larval TRANSport Model } \\ \text { LUMCON } & \text { Louisiana Universities Marine Consortium } \\ \text { MDDNR } & \text { Maryland Department of Natural Resources } \\ \text { MDMR } & \text { Mississippi Department of Marine Resources } \\ \text { MDWFP } & \text { Mississippi Department of Wildlife Fisheries and Parks } \\ \text { MDEO } & \text { Mississippi Department of Environmental Quality } \\ \text { NCDC } & \text { NOAA's National Climatic Data Center } \\ \text { NC DEO } & \text { North Carolina Department of Environmental Quality } \\ \text { NC DMF } & \text { North Carolina Department of Marine Fisheries } \\ \text { NC WRC } & \text { North Carolina Wildlife Resources Commission } \\ \text { NERRS } & \text { National Estuarine Research Reserve System } \\ \text { NOAA } & \text { National Oceanic and Atmospheric Administration } \\ \text { NODC } & \text { National Oceanographic Data Center } \\ \text { NPZD } & \text { Nutrient Phytoplankton Zooplankton Detritus model } \\ \text { NRDA } & \text { Natural Resource Damage Assessment } \\ \text { NWOMC } & \text { National Water Quality Monitoring Council } \\ \text { OSI } & \text { Oyster Suitability Index } \\ \text { POM } & \text { Princeton Ocean Model } \\ \text { RMA } & \text { Resource Modelling Associates } \\ \text { ROMS } & \text { Regional Oceans Model System } \\ \text { ROI } & \text { Reef Quality Index } \\ \text { RSI } & \text { Restoration Suitability Index } \\ \text { SBM } & \text { shell budget model } \\ \text { SCHISM } & \text { Semi-implicit Cross-scale Hydroscience Integrated System Model } \\ \text { SELFE } & \text { Semi-implicit Eularian-Lagrangian Finite-Element model } \\ \text { SFWMD } & \text { South Florida Water Management District } \\ \text { SFWMM } & \text { South Florida Water Management Model } \\ \text { SI } & \text { Suitability Index } \\ \text { SONRIS } & \text { Strategic Online Natural Resources Information System } \\ \text { TISS } & \text { total inorganic suspended sediments } \\ \text { TroSIM } & \text { Trophic Simulation Model } \\ \text { TPWD } & \text { Texas Parks and Wildlife Department } \\ \text { TSS } & \text { total suspended sediments } \\ \text { TWDB } & \text { Texas Water Development Board } \\ \text { USACE } & \text { U.S. Army Corps of Engineers } \\ \text { USFWS } & \text { U.S. Fish and Wildlife Service } \\ \text { USGS } & \text { U.S. Geological Survey } \\ \text { VIMS } & \text { Virginia Institute of Marine Science } \\ \text { WASP } & \text { Water Quality Analysis Simulation Program } \\ & \end{array}$




\title{
Oyster Model Inventory: Identifying Critical Data and Modeling Approaches to Support Restoration of Oyster Reefs in Coastal U.S. Gulf of Mexico Waters
}

\author{
By Megan K. La Peyre, ${ }^{1}$ Danielle A. Marshall, ${ }^{2}$ and Shaye E. Sable ${ }^{3}$
}

\section{Executive Summary}

Along the coast of the U.S. Gulf of Mexico, the eastern oyster (Crassostrea virginica) plays important ecological and economic roles. Commercial landings from this region account for more than 50 percent of all U.S. landings; these oyster reefs also provide varied ecosystem services, including nursery habitat for many fish and macroinvertebrate species, shoreline protection, and water-quality maintenance. Declining trends in both total oyster production and functional reef area across this region have spurred investment in restoration of oyster resources, with specific calls for restoration projects to develop a network of reefs and identify broodstock and sanctuary reef restoration sites. Decision making related to restoration and establishment of a network of oyster reefs in the Gulf of Mexico requires information on both the environment and the effects of the environment on the oyster life cycle (including larval movement, survival, oyster recruitment, reproduction, growth, and mortality). Here, we examined the current state of data and model development in this region with the goal of providing an overview of oyster modeling approaches and an inventory of available data and existing oyster models. This report is meant to provide an overview to managers for understanding existing efforts and identify a path forward to most efficiently inform oyster resource management and restoration planning in moving from a single reef management approach to a reef network management approach.

Numerous models related to some aspect of the oyster life cycle have been built, calibrated, and validated for various Gulf of Mexico estuaries over the last few decades (over 30 models identified). These models, which could inform site restoration, can be classified into four approaches: (1) oyster Habitat Suitability Index (HSI) models; (2) larval transport models; (3) on-reef oyster models that may include oyster growth, mortality and reproduction, and substrate persistence; and (4) coupled larval transport on-reef metapopulation models that simulate the entire oyster life cycle. The data requirements, model complexity and assumptions, and transferability vary by approach. Specifically, some approaches may offer greater accessibility, flexibility, and transferability spatially or temporally, with minimal data input, but only provide broad information to support site selection. In contrast, other approaches may require significant site-specific data for their construction and validation but may provide more accurate and location-specific data to support site selection for broodstock reefs.

Regardless of modeling approach used, data on environmental drivers, such as salinity, water temperature, or water flow impacting oyster metabolism and movement, are required at appropriate spatial and temporal scales. While numerous data collection platforms, environmental models, and research products exist within Gulf of Mexico estuaries to provide important environmental data to use as drivers in the oyster models, significant variability in temporal and spatial coverage of the data, and variation in the availability of future condition models, exists across estuaries. This variation influences the spatial and temporal scales at which oyster models may be developed and impacts the calibration and validation of the oyster models within a given estuary, affecting its potential ability to address specific management or restoration questions.

While multiple modeling approaches exist for informing site selection of broodstock or sanctuary oyster reefs, the development, calibration, and validation of a single modeling platform presents the most efficient, transferable, and useful tool for managers across the Gulf of Mexico. The development of a single modeling platform would involve using standardized input variables, governing equations, and assumptions for the modeled oyster processes and outputs, and for standardized calibration and validation procedures that could be applied within each estuary. The differences among estuary applications would require substituting only estuary-specific environmental data, and calibrating and validating the modeling approach with local oyster data.

\footnotetext{
${ }^{1}$ U.S. Geological Survey.
}

${ }^{2}$ School of Renewable Natural Resources, Louisiana State University Agricultural Center, Baton Rouge, Louisiana. 
Two modeling approaches likely to be useful include (1) development of a general geospatial HSI modeling framework that could be applied consistently across estuaries and (2) a mechanistic coupled larval transport on-reef metapopulation model requiring only estuarine specific calibration and hydrodynamic models. Both approaches benefit from existing work across multiple Gulf of Mexico estuaries and could provide valuable support for oyster restoration, but may differ in their ability to address specific questions related to oyster restoration. HSI models specifically guide restoration practitioners in determining suitable habitat based on available data. The HSI approach, while currently more widely used and accessible, requires more development of larval suitability and larval input and output components in order to inform reef connectivity. A metapopulation approach considering the full oyster life cycle that simulates both on-reef oyster growth, mortality, reproduction, substrate persistence, and larval transport (ideally with larval growth and mortality) would provide the greatest detail and level of understanding but requires significant up-front investment. The larval oyster model and on-reef oyster model are usually developed independently for systems, although the two approaches can be coupled to represent the entire oyster life cycle in order to characterize and assess a reef metapopulation. This approach may be less accessible and much more data-intensive, however, and it requires some expertise to run and apply to inform oyster resource management.

Ultimately, the development of single modeling platforms for each of these approaches would provide flexible tools applicable across all Gulf of Mexico oyster supporting estuaries. By using a single platform for model development, testing, calibrating and validating, and evaluation of modeled future scenarios, oyster restoration scientists and managers would not only be able to examine different scenario outcomes within a single estuary, but could also have comparable modeled results to evaluate potential outcomes, across estuaries and regions, that are not confounded by varying modeled data inputs, governing equations, assumptions, or user judgement.

\section{Introduction}

Along the U.S. coast of the Gulf of Mexico, the eastern oyster (Crassostrea virginica) plays important ecological and economic roles. In 2018, commercial oyster landings from the Gulf of Mexico generated an estimated \$104 million, accounting for more than 50 percent of all U.S. landings (NOAA, 2020). Oyster reefs also provide various ecosystem services, including but not limited to habitat provision for fishes and macroinvertebrates (La Peyre and others, 2019), shoreline protection (La Peyre and others, 2015), or denitrification (Kellogg and others, 2013), with estimated ecosystem services values of over $\$ 5,500$ per hectare-year (Grabowski and others, 2012). However, over 50 percent of native oyster populations have been estimated to be functionally lost in the region (Beck and others, 2011), and oyster reefs have been identified as being vulnerable to future coastal development and climate change (Reece and others, 2018). Changes in water quality - from direct anthropogenic activities including river management, diversions, and oil spills - along with impacts from changing climate may impact existing oyster reefs, shifting suitable habitat conditions (Wang and others, 2017) and impacting oyster growth, reproduction, and survival.

In response to declines in harvest and critical ecosystem services provided by reefs, numerous restoration efforts have been implemented. To date, most restoration efforts and their assessments have been implemented as isolated, individual reef-level projects with mixed success (Kennedy and others, 2011; La Peyre and others, 2014); further, these efforts often fail to acknowledge that oysters' long-term sustainability depends on reef connectivity through larval transport. As optimal environmental conditions shift across the estuarine gradient from habitat management and climate change, assessing oyster resources and managing for sustainability would benefit from a metapopulation approach (Lipcius and others, 2008, 2015; Puckett and others, 2018). A metapopulation approach to oyster reef management explicitly examines how individual reefs are connected and maintained through movement of oyster larvae between reefs.

Recent planning documents call for the development of a network of reefs in the Gulf of Mexico to restore oyster abundance and spawning stock, thereby increasing resilience and restoring ecosystem services provided by oyster reef habitats (Deepwater Horizon Natural Resource Damage Assessment Trustees [DWH NRDA], 2017). Effectively implementing this type of restoration program requires targeted site selection within and across estuaries. In Atlantic coast estuaries, several modeling approaches provide critical tools to identify and guide site selection to develop a network of oyster restoration sites (Puckett and others, 2018; Theuerkauf and others, 2019). Such an approach involves using hydrodynamic, bathymetric, bottom type, ecological, particle transport, and oyster biology data and models to support decision making.

A first step to implementing this approach in the Gulf of Mexico involves identifying critical data and models necessary to support site selection and compiling an inventory of available data and modeling approaches. With a list of data, model needs, and data and model availability, restoration practitioners can leverage existing data and models and focus on developing and acquiring needed data and models to inform restoration efforts. This report has been prepared to provide background on data, model needs, and data and model availability for Gulf coast oyster restoration planning.

\section{Approach}

Restoration of oyster resources that accounts for the entire oyster life cycle, connectivity of suitable habitat patches, and key driving environmental factors incorporates larval movement, recruitment, and on-reef oyster processes such as growth, reproduction, and mortality. This approach requires data on water-quality, ecological, and physical drivers that control on-reef oyster processes and larval transport, thereby connecting reefs (fig. 1). 
Implementing a strategic integrated approach to site selection for restoring a network of connected reefs by leveraging existing data and models requires (1) understanding what data (drivers) are critical to informing the model; (2) identifying available data and models within the region of interest to support site selection for broodstock reefs; and (3) developing connected oyster reefs throughout an estuary to ensure sustainability through years with varying environmental conditions. This report provides a synthesis of current resources available across the Gulf of Mexico. These goals are achieved through two primary tasks.

Task 1: Provide a review of the environmental drivers necessary to inform oyster models for site selection-This task, presented in the Eastern Oyster (Crassostrea virginica): Environmental Drivers section, provides a brief synthesis of our knowledge on drivers of eastern oyster growth, reproduction, mortality, and reef connectivity. The synthesis summarizes the current literature and is used to develop a table that lists variables representing ecological (for example, predation, disease), water-quality (for example, salinity, temperature) and physical (for example, water movement, substrate) drivers important to informing oyster reef restoration, including siting of broodstock sanctuaries and metapopulation planning.

Task 2: Identify data needs and modeling approaches and availability across our study area related to oyster modeling, ranging from larval transport, to on-reef growth, reproduction, and mortality, to reef connectivity-This task, presented in the Data, Models, and Approaches (Inventory) section, involved searching peer-reviewed and grey literature to identify relevant long-term data collection and completed modeling work useful to development of oyster life cycle models. This work identified both discrete and modeled data of ecological, water-quality, and physical variables identified through task 1 , further indicating geographic availability of these data by estuary. Further, a review of modeling approaches related to various aspects of oyster growth, survival, reproduction, larval movement, and reef connectivity identified four major approaches used in the past and identified geographically where such models have been calibrated and validated and may be available for use.

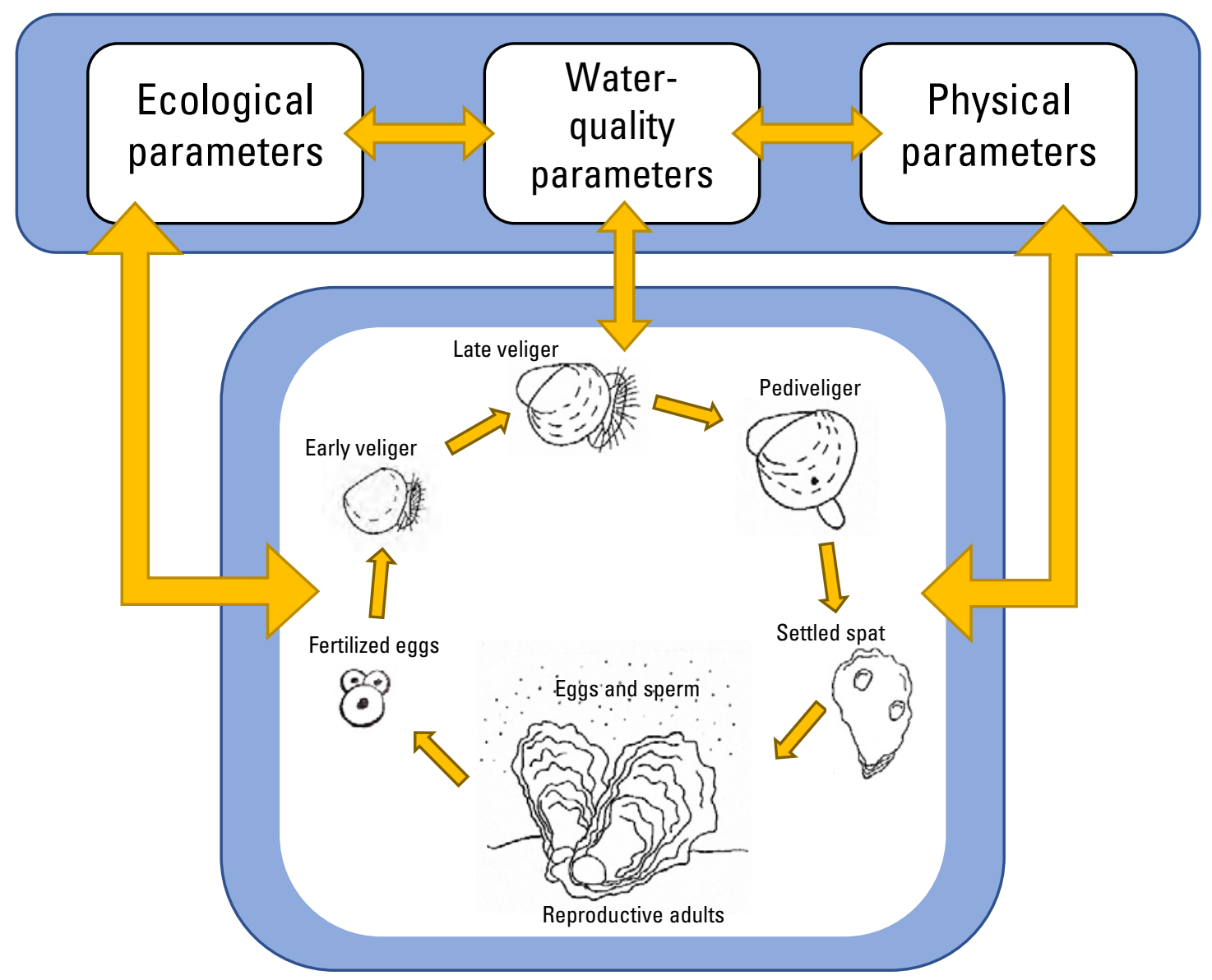

Figure 1. Conceptual model of data and model needs for informing eastern oyster restoration planning using a metapopulation approach. Ecological, water-quality, and physical parameters drive oyster growth, reproduction, survival, recruitment, and reef development across a network of connected reefs. Oyster spat may settle on the same reef as parents but are equally or more likely to settle on other reefs because of larval transport. 
Oyster Model Inventory: Identifying Critical Data and Modeling Approaches to Support Restoration of Oyster Reefs

\section{Geographic Scope}

Across the coastal waters of the U.S. Gulf of Mexico, the eastern oyster remains the dominant reef-building organism, existing in coastal and estuarine areas that vary in morphology and hydroclimatology (Orlando and others, 1993). The resulting complex geomorphology of this region encompasses over 20 estuaries that receive freshwater inflow from numerous rivers draining over 80 percent of the coterminous United States. Rivers and their inflows vary by orders of magnitude, with many impacted by anthropogenic management. In evaluating many of these estuaries, Orlando and others (1993) identified five estuary types ranging from marine to more terrestrial impacted estuaries but acknowledged that even within these groupings, differences exist in basin geomorphology impacting Gulf water exchange, wind, and bathymetry, resulting in high variability in salinity, nutrients, and functional differences between estuaries. These differences in geomorphology result in estuarine-specific conditions, impacting oyster reef distribution and oyster abundances (fig. 2). Such estuarine-specific characteristics likely also include unique circulation patterns, impacting reef connectivity via larval transport within each estuary and potentially between estuaries. The net effect is that identifying areas for oyster restoration and management, as well as modeling oyster populations, requires models that are able to function across a wide range of conditions.

\section{Eastern Oyster (Crassostrea virginica): Environmental Drivers}

Eastern oysters are estuarine organisms, with all life stages occurring in coastal areas, bays, and estuaries of the U.S. Atlantic and Gulf coasts (Patillo and others, 1997). With the exception of the beginning of an oyster's life when they are planktonic larvae for 2-3 weeks and disperse through the estuary, oysters are sessile once recruited. As planktonic larvae, they may be dispersed over distances of meters to many kilometers from their parental populations, based on a combination of hydrographic processes at multiple scales, water-quality conditions, and larval behavior (Atwood and Grizzle, 2020; North and others, 2008; and review in Bayne, 2017). Ultimately, larvae will attach to hard substrates where they grow, cement, and build clusters, assembling into oyster reefs. Oyster reefs build and maintain themselves through the continued growth and mortality of recruited oysters, which provide the substrate for continued reef existence. A lack of appropriate substrate in suitable locations may limit the ability of oysters to build reefs, and substrate addition remains a key tool in reef restoration. Where substrate exists, oysters grow and create reefs in highly variable estuaries with conditions changing over tidal, seasonal, and annual timescales, influenced by riverine and marine processes and events.
Virtually every aspect of oyster physiology and ecology is controlled by temperature, salinity, and food availability (Shumway, 1996; Bayne, 2017). Eastern oyster growth typically occurs between 5 and $34^{\circ} \mathrm{C}$, (Shumway, 1996), with recent research suggesting a threshold where feeding is potentially inhibited in the mid-30s $\left({ }^{\circ} \mathrm{C}\right)$ (Kennedy, 1996; Rybovich and others, 2016). As models predict increasing numbers of days with temperatures above $32{ }^{\circ} \mathrm{C}$ per year and increasing record high temperatures and duration of heat waves (Keim and others, 2011; Biasutti and others, 2012), this threshold may become increasingly limiting. Recent models considered winter mortality in Gulf of Mexico oyster populations negligible based on extensive field data (Wang and others, 2017). Reproduction is highly dependent on water temperature, with a reported range of spawning occurring from 15 to $28^{\circ} \mathrm{C}$ (Bayne, 2017), most spawning occurring at temperatures greater than $(>) 25^{\circ} \mathrm{C}$ in the Gulf of Mexico (Hayes and Menzel, 1981), and normal egg development reported between 18 and $30{ }^{\circ} \mathrm{C}$ (Loosanoff, 1965).

In the Gulf of Mexico, where temperatures normally exceed $10{ }^{\circ} \mathrm{C}$ during most of the year, oysters may spawn multiple times throughout the year (Choi and others, 1993, 1994; Supan and Wilson, 2001). As oysters are broadcast spawners, numerous eggs from individual oysters have been reported (for example, 115 million eggs; Galtsoff, 1964); however, few estimates of larval survival and settlement exist, and many larvae are assumed to die prior to settlement through predation, inadequate water-quality conditions, or failure to find suitable substrate (larval to spat survival rate $\sim 1 \times 10^{-8}$; Wang and others, 2017). Predictions of actual spawning events and fecundity remain elusive, as many variables other than temperature also control oyster fecundity, including salinity, food availability, or disease (Mroch and others, 2012; Mann and others, 2014; Marshall and others, 2020).

Eastern oysters and their reefs generally occur at salinities from 5 to 40, with tolerance to salinities below 5 and above 40 highly dependent on interacting factors such as temperature (Shumway, 1996). Optimal salinity is estimated to range between 12 and 24 for settled oysters but may be size dependent (Shumway, 1996) and is impacted by other factors such as temperature (Lowe and others, 2017). At higher water temperatures, oyster tolerance to low salinities is reduced (Rybovich and others, 2016). In contrast, at lower water temperatures (that is, less than $[<] 25^{\circ} \mathrm{C}$ ), oysters can survive in salinities less than 3 for periods longer than 3 months (for example, Petes and others, 2012; La Peyre and others, 2013; Rybovich and others, 2016; Lowe and others, 2017). Optimal salinity for eggs and larvae is likely related to the salinity at which the adult gonads completed gametogenesis, with most larvae tolerating salinities between 5 and 39 (Castagna and Chanley, 1973), though larval growth or survival is typically limited at lower salinities (that is, salinity $<10$; Loosanoff, 1965; Lough, 1975).

While oyster larvae can be highly dispersive within estuaries, suggesting that populations may share genetic resources, evidence suggests local adaptations in tolerance 


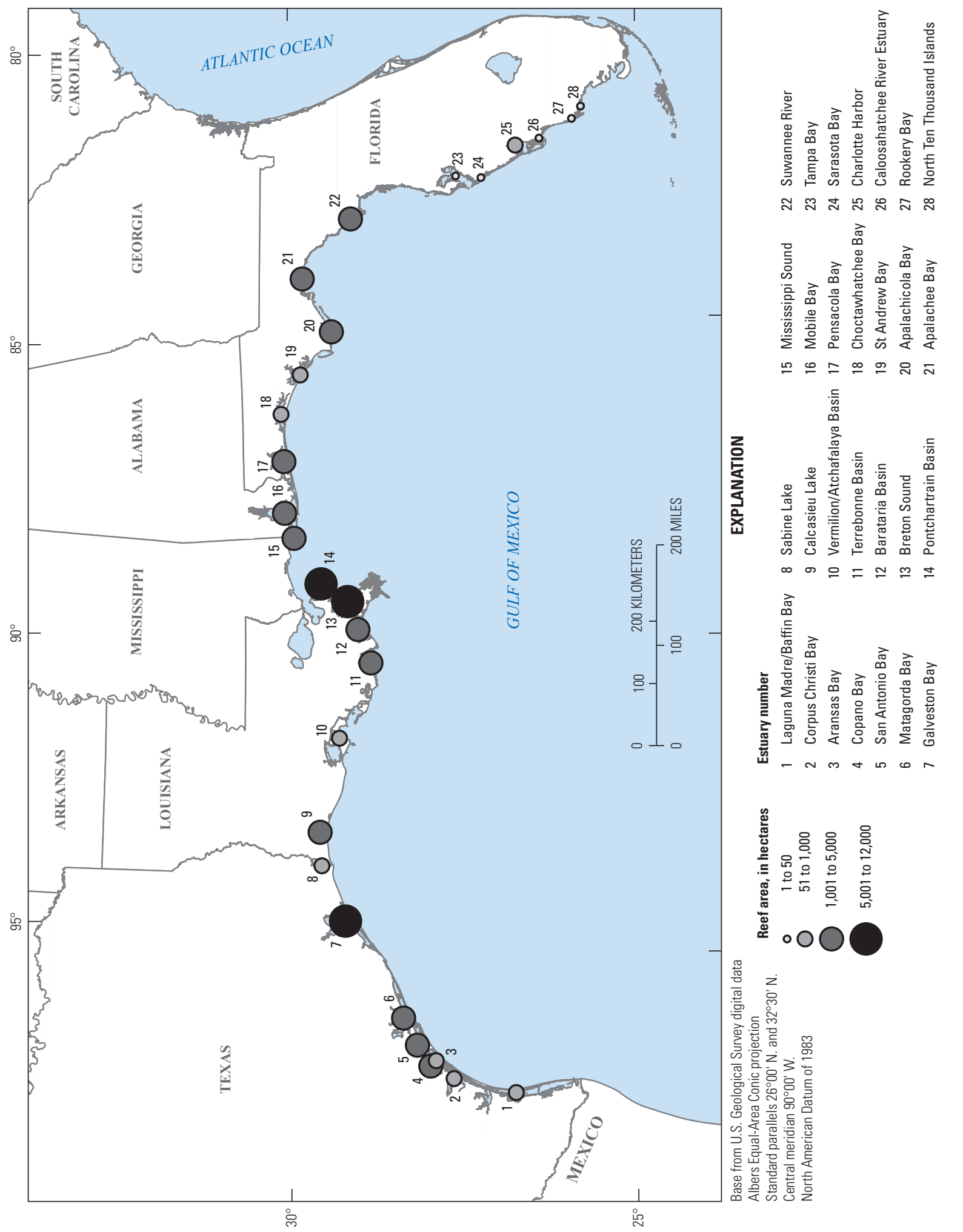

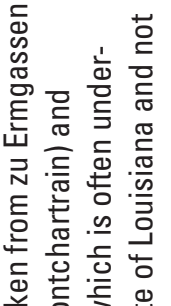

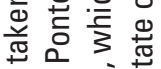

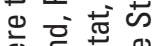

要言蓄垔

sis $\frac{\pi}{4}$

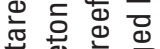

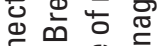

吾焉

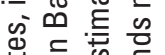

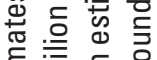

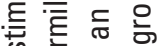

\&

『ँ⿱

ฮั

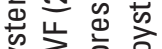

要主高

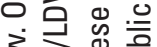

岁守导言

ذ. పิ

象嵒 氕

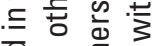

웡들

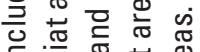

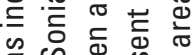

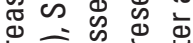

๘

폰

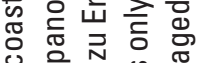

응

들

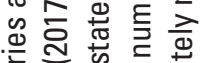

\% क क

芦造迹

ब $\sum^{\pi} \dot{\overline{0}} \frac{5}{3}$

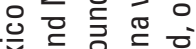

정

$\sum$ 这高告

눙 웡응 호음

生品.

ज क्ष

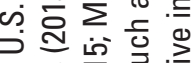

क⿺辶万 क क

눰웛

는엄ㄴㅎㅇ

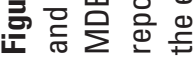


among oyster populations (Varney and others, 2009; Burford and others, 2014; Eierman and Hare, 2016). For example, local adaptation in Gulf of Mexico oyster populations has been shown for disease tolerance (Leonhardt and others, 2017) and for salinity tolerance, with progeny of oysters from a highsalinity estuary (that is, annual mean salinity $\sim 35$ ) having less tolerance to low salinities than progeny of oysters from a lowsalinity estuary (that is, annual mean salinity $\sim 10$; Marshall and others, in press). Specific local adaptations may be important when seeding reefs with hatchery produced stock, or when considering broodstock for aquaculture within estuaries, as broodstock may be selected to match local site characteristics (Leonhardt and others, 2017). Equally important to consider are the impacts of salinity on overall oyster survival and reef growth as they relate to localized tolerance(s) to biotic factors, namely, disease and predation (that is, ecological tolerance [Bayne, 2017]).

In the Gulf of Mexico, the disease dermo, caused by the parasite Perkinsus marinus, is more prevalent among oysters at higher salinities and temperatures, and can be the source of extensive mortality in oyster populations (Craig and others, 1989; Soniat, 1996). However, increased freshwater inflow (that is, decreased salinity) can regulate the prevalence and severity of dermo and maintain nonlethal intensities (La Peyre and others, 2003). Similarly, predation is another cause of mortality at higher salinities as oyster predators generally increase in abundance and biomass with salinity, and lower salinities limit their distribution (Wells, 1961). For example, the oyster drill (Stramonita haemastoma) and the stone crab (Menippe mercenaria) are restricted to salinities above 12-15 (Menzel and others, 1958; Garton and Stickle, 1980;

MacKenzie, 1981) where they are capable of decimating local oyster populations, particularly the smaller size classes (that is, shell height $<50$ millimeters).

In addition to temperature and salinity, food provides the energy for oyster growth and reproduction to occur, and food availability critically informs many oyster models. As filter feeders, oysters feed on seston suspended in the water column, with most assimilated carbon derived from phytoplankton (Haines and Montague, 1979; Langdon and Newell, 1996). Oysters may feed selectively based on particle size (for example, Jorgensen, 1966; Haven and Morales-Alamo, 1970; Riisgård, 1988), shape (Rosa and others, 2013, 2018), and food quality (for example, Newell and Jordan, 1983), and may also preferentially select phytoplankton species based on cellsurface biochemical signatures (Ward and Shumway, 2004; Pales-Espinosa and others, 2008). Differences in water-quality conditions impact phytoplankton communities and may result in differences in food availability (quantity and quality of organic matter) across estuaries (Bargu and others, 2019; Aguilar Marshall and others, in press; Weissberger and Glibert, 2021). As a result of selective feeding behavior and constantly changing phytoplankton communities within estuaries, oyster models focus on the use of proxies for food. The concentration of chlorophyll $a$ is the most commonly used proxy. This choice is based on early research indicating that particulate lipids, carbohydrates, and proteins provide a good measure of oyster food availability (Widdows and others, 1979), and the demonstrated relationship between these lipids, carbohydrates, and proteins, and chlorophyll $a$ concentration (Powell and others, 1997). Numerous models in the Gulf of Mexico rely on this relationship (for example, Dekshenieks and others, 2000), although many other proxies have also been explored (for example, phytoplankton carbon or density; Bourlès and others, 2009; Ren and Schiel, 2008; Bayne, 2017) with data availability often driving the selection of food proxies. Oyster models in the Gulf of Mexico have either assumed food is not limiting (that is, Lavaud and others, 2017), used available chlorophyll $a$ concentration data, or linked food availability to on-reef oyster density and current velocity (that is, Wang and others, 2017); generally, data on food quality and quantity specifically linked to oyster growth and reproduction remain limited.

Water movement also influences oyster growth or survival by regulating food availability (Klinck and others, 1992; Wang and others, 2017). Determining food availability remains complex, as it can be a function of food concentration (quantity), food quality, reef density, and filtration rates (Wilson-Ormond and others, 1997). Further, Galtsoff (1964) suggested that only food passing within a 2-centimeter radius of the oyster shell was likely available to the oysters, suggesting only a small portion of the water column and food resources are available to the oysters (Wilson-Ormond and others, 1997). The interactions of food availability and flow, however, make it difficult to identify thresholds. For example, low food quantity in high-flow conditions may constitute a similar food availability as high food quantity in low-flow conditions. Further, filtration, or feeding activity, varies by temperature and salinity (Casas and others, 2018), and such activity may also be inhibited by higher flow rates, with studies suggesting filtration ceases at a threshold of $\sim 15$ centimeters per second (Dame and others, 1989; Grizzle and others, 1992).

Beyond salinity, temperature, and food availability, other factors that may impact oyster population sustainability include sediment accretion, substrate, dissolved oxygen, turbidity, and water movement (currents/speed, discussed above in relation to food availability). While these factors influence oysters throughout their life history and impact reef sustainability, their impacts are tightly coupled to the key variables of temperature, salinity, and food availability; further, many of these factors lack data to support estuary-wide modeling efforts.

Oyster burial in 40-60 millimeters of sediment can result in oyster mortality (Comeau, 2014), with lethal effects occurring as a result of complete burial over a 28-day period (Colden and Lipcius, 2015). Additionally, even low sediment accretion rates on the order of a few millimeters per day can inhibit spat settlement during the reproductive season by making the surfaces unavailable for attachment (Galtsoff, 1964; Thomsen and McGlathery, 2006). Recent laboratory experiments examining impacts of high total suspended 
sediments (TSS) on oyster metabolism found limited negative effects from acute or extended (60-day) periods of exposure to TSS levels up to 400 milligrams per liter (mg/L) (La Peyre and others, 2020). Estimates of sediment accretion for extended periods, or for continued exposure to high sediment loads, are lacking.

Similarly, while low dissolved oxygen levels $(<1 \mathrm{mg} / \mathrm{L})$ have been indicated as a cause of sublethal stress and (or) mortality (Lenihan and Peterson, 1998; Patterson and others, 2014), limited field data exist to support extensive modeling or response data for oysters, though some studies suggest a minimum dissolved oxygen level for oysters (>3 mg/L, Linhoss and others, 2016; $>4 \mathrm{mg} / \mathrm{L}$, Patterson and others, 2014). While oysters may tolerate short periods of low dissolved oxygen levels, this tolerance varies based on exposure to other stressors, such as salinity and temperature (Stickle and others, 1989).

Changing estuarine conditions impact oyster populations and areas suitable for their growth. Such changes may be caused by increases in the frequency and (or) magnitude of (1) storm events; (2) riverine inflow alterations; (3) abrupt or long-term changes in temperature, salinity, food resources; and (4) gradient shifts within estuaries. Cyclical events, such as the El Niño Southern Oscillation (ENSO) within the Gulf of Mexico, impact oyster disease and populations through their effects on estuarine salinity (Soniat and others, 2012b), while long-term changes in water quality across this region result in changing demography and fewer large oysters across the region (Powell, 2017).

Informing site selection for oyster restoration and identifying suitable areas for broodstock or sanctuary reefs (1) require input that accounts for historic, current, and predicted changes, and (2) acknowledge the high temporal and spatial variation inherent to estuaries. Our current understanding of water-quality, ecological, and physical drivers controlling on-reef oyster processes, larval movement, and survival motivates the inclusion of these critical variables in oyster restoration site selection and influences overall metapopulation dynamics.

From the literature review, critical variables were identified as those used in most models to determine suitable and optimal locations for siting broodstock and sanctuary reefs in the Gulf of Mexico (table 1). Broodstock reefs are generally considered reefs sited in areas expected to be conducive to oyster reproduction on a regular basis and are located so that they potentially could provide larvae to seed adjacent reefs. Sanctuary reefs are considered reefs that might be protected from harvest, but they may exist across the full range of locations conducive to oyster growth over time. For a number of variables, such as food availability, larval transport, and reef recruitment, the hypotheses related to them can be explicitly tested to provide improvements in models. These hypotheses include the relationship between food resources, indicators of food availability (that is, chlorophyll $a$ concentrations), flow rates and food ingestion, and the effects of changing salinity and temperature on food availability.
Explicit recognition of the significant upfront investment and the decades of research that supported the development of species models and linking such models to changes in environmental conditions across a spatial framework are critical to acknowledge in moving forward with the development of additional modeling platforms for the Gulf of Mexico. While important for planning and implementation, logistical factors were not included as these are unique to each estuary, and location often reflects not only geography, but also land ownership, policies, and laws. However, similar to the variables driving the models on oyster populations and larval movement, modeling could be used to explore outcomes and impacts of different logistical variables on restoration and management options.

\section{Data, Models, and Approaches (Inventory)}

The restoration and establishment of a network of broodstock oyster reefs in the Gulf of Mexico requires information on (1) the environment; (2) oyster recruitment, growth, mortality, and reproduction; and (3) the interaction of the two (fig. 3). Here, we identify environmental data and oyster-related models that can inform site selection for moving from single-reef management to management of a network of connected reefs (metapopulation). The Water-Quality, Ecological, and Physical Data section that follows broadly examines the availability of environmental data - discrete, modeled, and satellite data - that may be useful for model inputs in each of the study area estuaries. Next, the Oyster Model Inventory section provides an overview of the types of models used to examine oyster populations and identify models available (calibrated or validated) for each of the study area estuaries. These inventories are not meant to be exhaustive and instead are focused on data and models that are accessible, which is required for their use.

\section{Water-Quality, Ecological, and Physical Data}

Numerous data collection platforms, models, and research products exist for areas within the Gulf of Mexico, and they are often State- or estuary-specific (fig. 4, appendix 1, table 1.1). We provide an overview of the availability of water-quality, ecological, and physical data collected across Gulf of Mexico estuaries, including discrete or modeled data used to inform existing oyster models. This list is not meant to be exhaustive, nor does it capture data available from short-term collection or research projects. Instead, it provides an overview of the available data from long-term publicly available datasets across these estuaries.

Discrete data, collected by means of continuous data recorders or long-term field monitoring programs, provide the baseline data critical to informing many oyster models, either directly or through their use in informing spatially or 


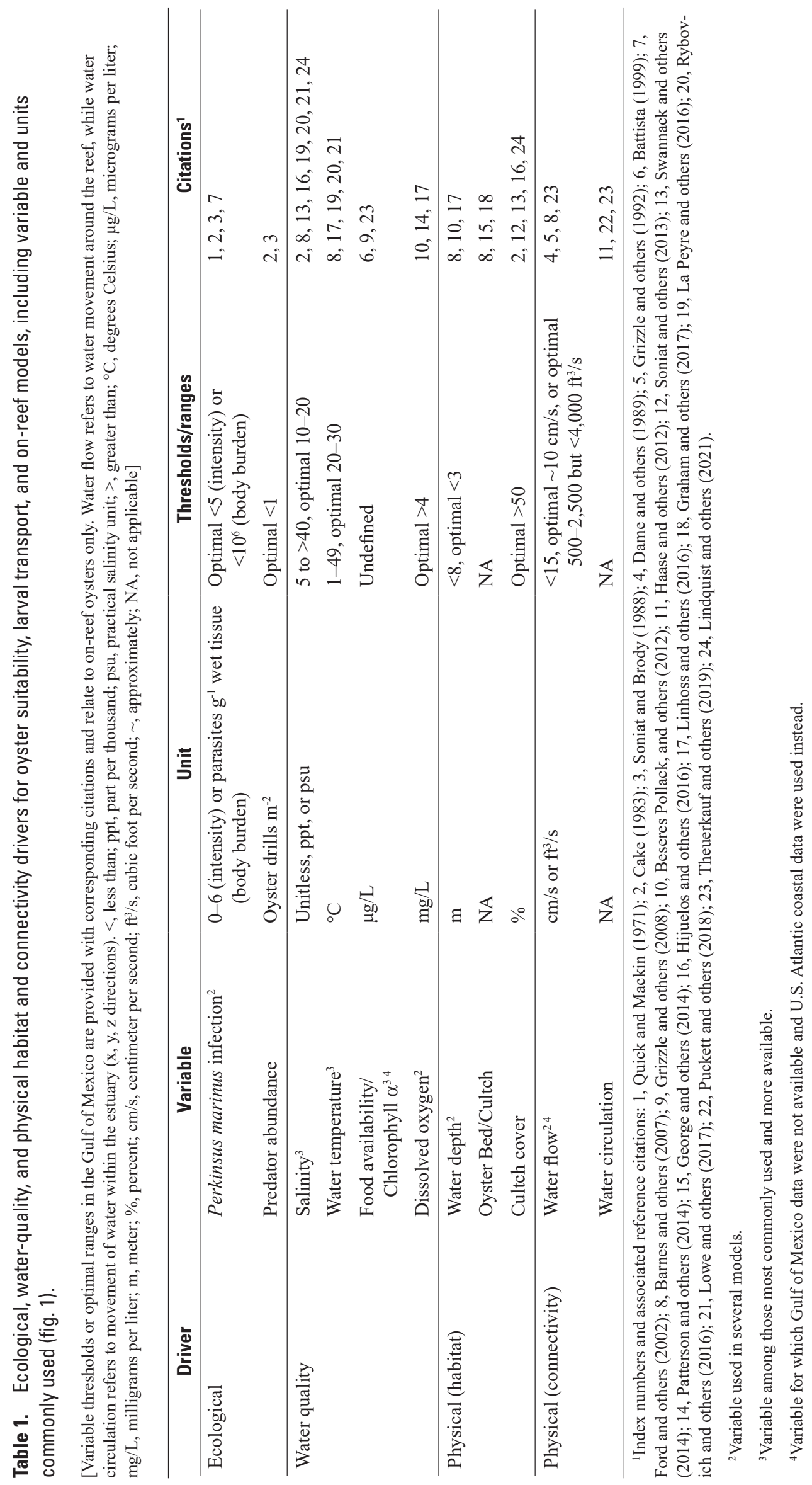




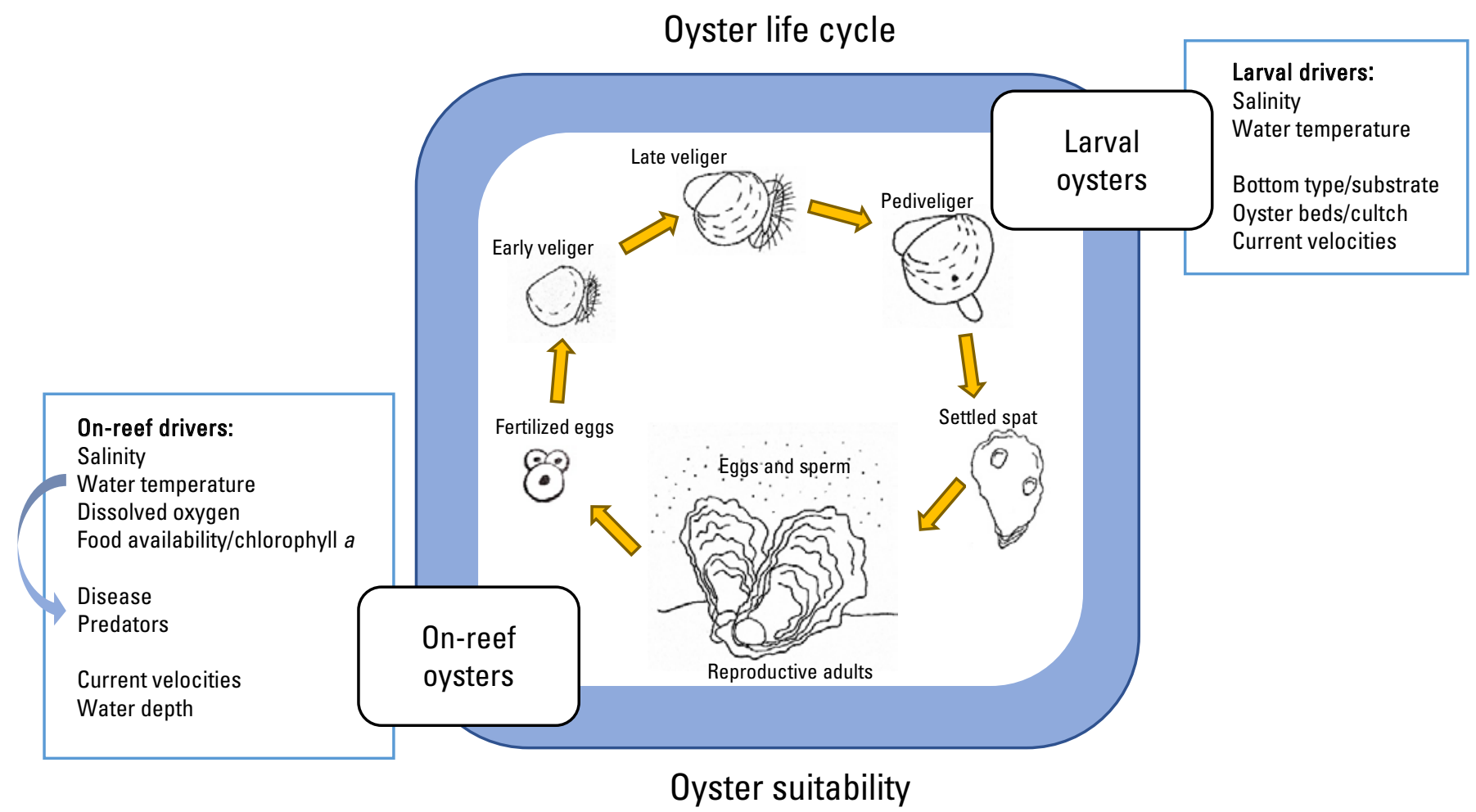

Figure 3. The oyster life cycle, on reef drivers, and larval drivers. The oyster life cycle consists of a short pelagic stage before settling in one location for life. Growth, reproduction, and survival are impacted by water-quality (salinity, water temperature, dissolved oxygen, and food availability), ecological (disease and predators), and physical drivers (current velocities, water depth, and oyster beds/cultch) of the substrate and overlying water column. Oyster spat may settle on the same reef as parents but are equally or more likely to settle on other reefs because of larval transport.

temporally interpolated or modelled environmental datasets. Most often, these long-term and continuous environmental data collections are implemented through State and Federal agencies (for example, Gulf of Mexico Alliance Water-Quality Team, 2013). While discrete ecological, water-quality, and physical data are widely available across Gulf of Mexico estuaries, significant variation remains in the spatial and temporal scales of these data across the estuaries (figs. 5 and 6).

In some cases, available data may represent one spatial location with hourly data collection, and in others, available data may represent many locations with monthly data collection. That is, although we indicate data collection is occurring, the quantity and quality of the data may be highly variable. For example, figure 7, which compares Calcasieu Lake and Barataria Basin in Louisiana, highlights the difference in the number of sampling stations and recorders between two estuaries in a single State. This variation may reflect differences in resources or simply differences in basin complexity, which could drive the need for more or fewer data points to accurately represent a basin. As a result, it is difficult to provide general recommendations related to minimum spatial or temporal data requirements, as this potentially reflects two different monitoring paradigms: fine spatial/temporal resolution data over short-term periods of record versus coarse spatial/temporal resolution over longer-term periods of record. These differences can impact the applicability and type of models available, and may also present challenges to ensuring units or scales are compatible when trying to couple models together (for example, different hydrodynamic and biological data). These differences in the spatial and temporal resolution of data along with coupling different model types are a central challenge to the modeling and management of an oyster metapopulation. As an example, using just the larval oyster stage, the interaction between larval transport and condition with salinity and temperature ranges estimated from experimental data and provided by fine-scale hydrodynamic model data over a network of reefs within the few-square-kilometer scale of an estuary differs compared to how monthly or averaged summer temperature and salinity data collected over many years at numerous monitoring stations are determined to affect spat sets for an entire estuary.

Numerous 2D (two-dimensional in $\mathrm{x}, \mathrm{y}$ space) and 3D (vertical layers or representation added for $\mathrm{x}, \mathrm{y}, \mathrm{z}$ dimension) hydrologic or hydrodynamic, water-quality, and (or) circulation models can also provide modeled "data" for inputs to oyster models (figs. 5 and 6), but with greater spatial and temporal coverage than discrete data. However, the calibration and validation of these numerical models vary based on the availability of discrete data (temporal and spatial coverage) 


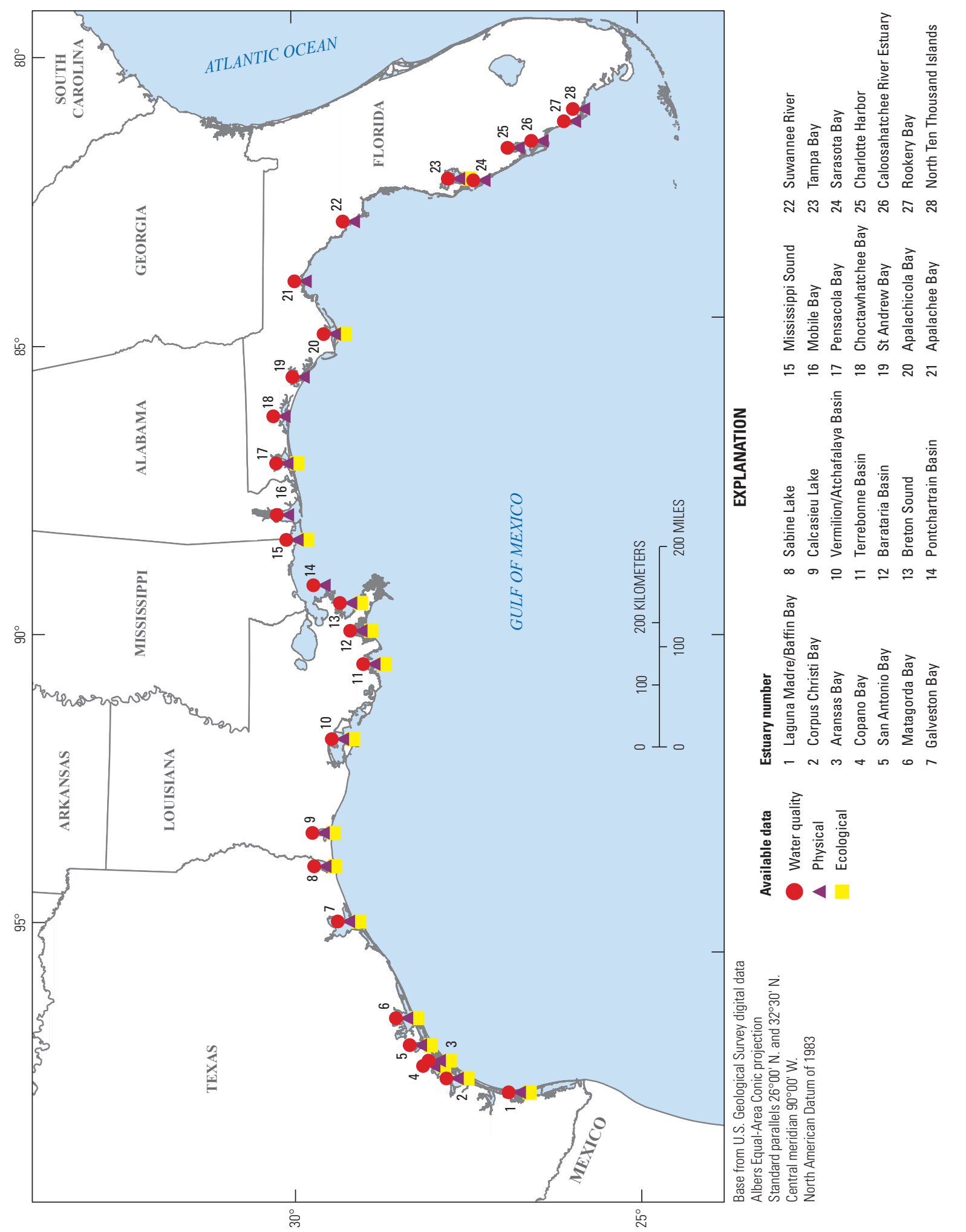

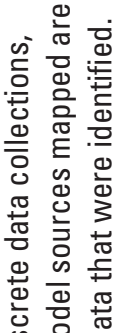

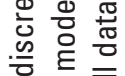

E

象要

$\therefore$ 造

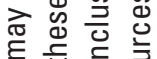

퓬

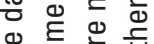

ฏ

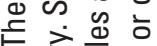

ฮृ त

정 ब

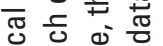

음 它 음 잉

은

记 䨌

¿ 3 is

స్ 인

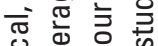

क ठ

至宁 元

‡ᄒ웡

흠 헣 증

1 음

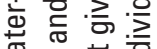

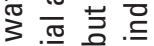

응 흏듬

흐음

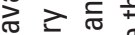

प

文离

들

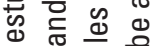

ठे 吾

ᄃ 응

은 은

정 क क 응

늘 는 을

등 흥 음

으 퓸

- 응 윰

음

言吾兽兽 

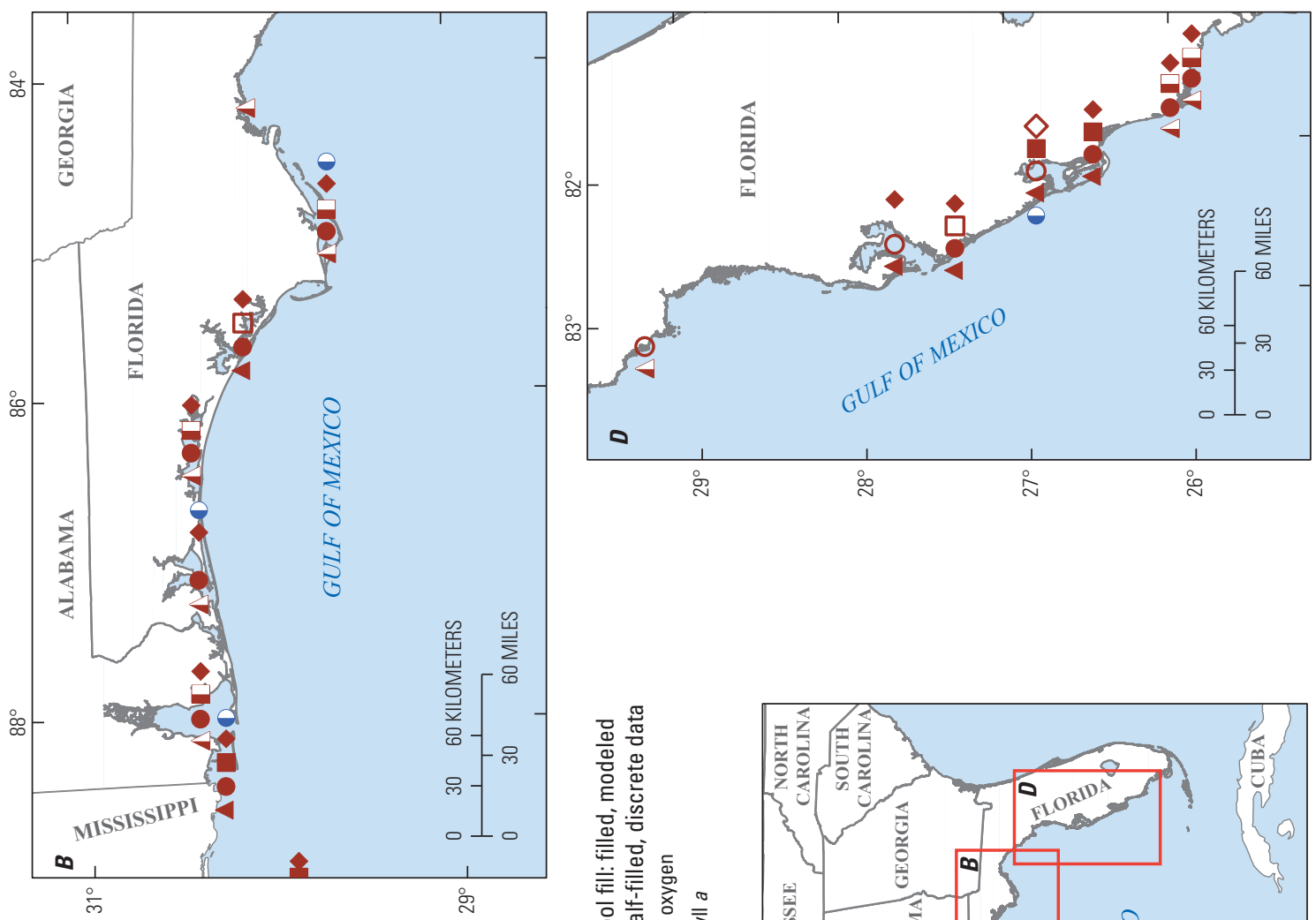

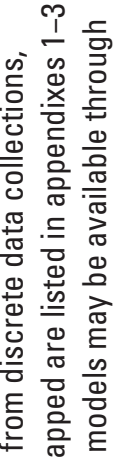

要

ब

है

密

$\Phi$ 苦

$\stackrel{\oplus}{\risingdotseq} E \dot{\Phi}$

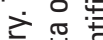
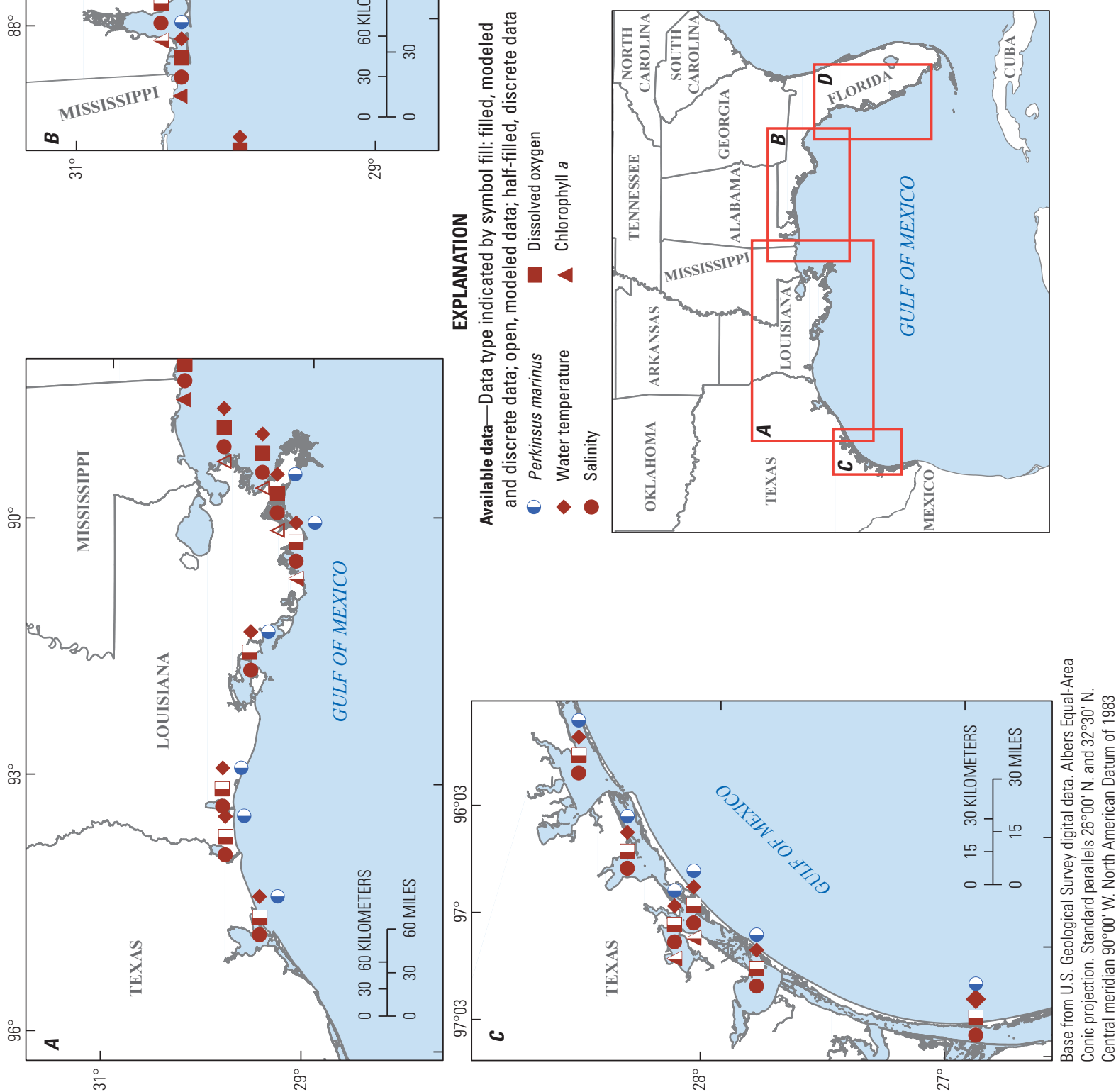

营 $\frac{\pi}{0}$

\&

응

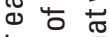

하요

\&

言交哭

is

음

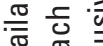

$\stackrel{\pi}{\varpi}$

츤

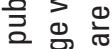

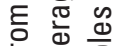

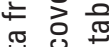

范

르웡

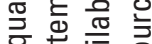

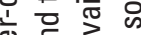

票市

उ. 정

등

정 $\subseteq \infty$

등 㲾元

응 $\frac{\pi}{>} E$

치

튼

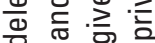

돌 志.

을 을

त है ले

힌휴

บ 히

告焉永

เ

잉 웡

훈을 홀. 

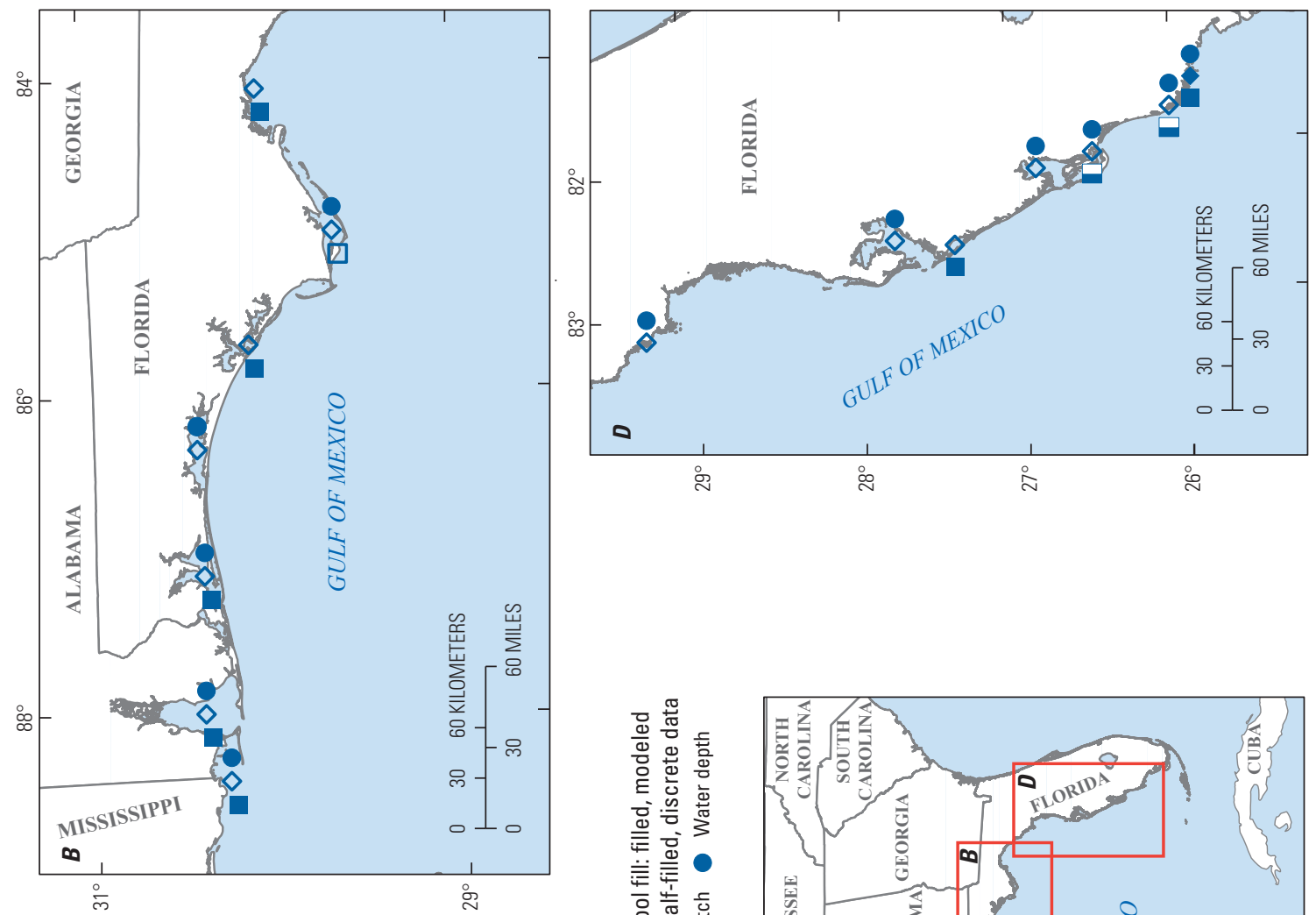

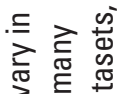

䎡

至

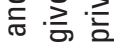

言吉哭

을

हो

흔

त造

등

क्ष

을 플

s)

응

$\stackrel{x}{ \pm}$

응

풍 응 $\frac{\pi}{\overline{0}}$
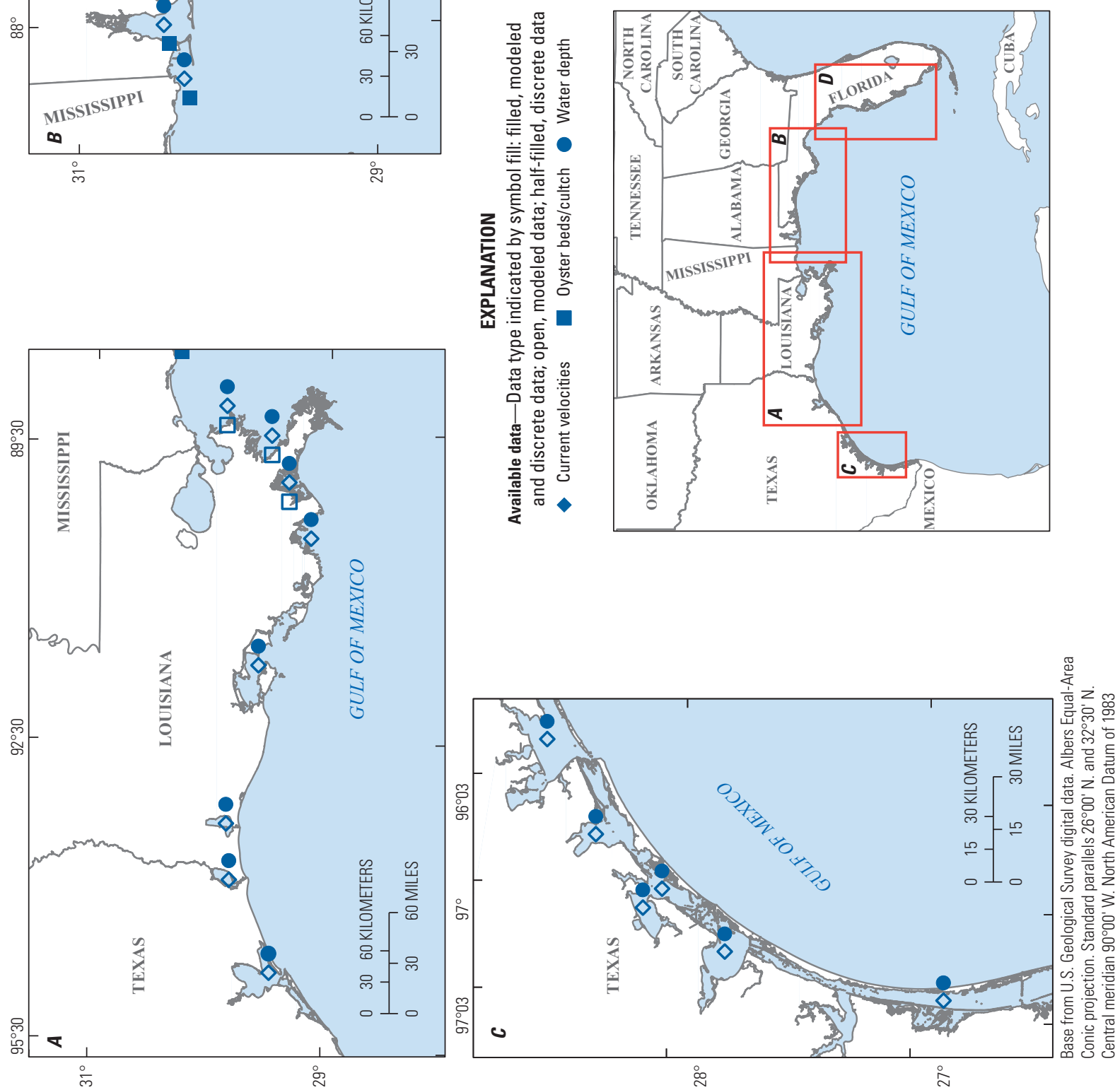

드

힝

它

क

등 흥

훙

त

E

要选

잉

\&

등

空它

屁

엉 즈

c

\&

훈

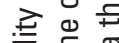

京

西

䨔

要苑

등

웡

츨

잉

$\frac{1}{0}$

중

E 힝

흥

ब

\%

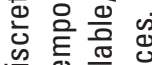

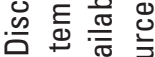

. 票元 क

๑ $\frac{\pi}{\sigma}$

产焉 创 证别的 

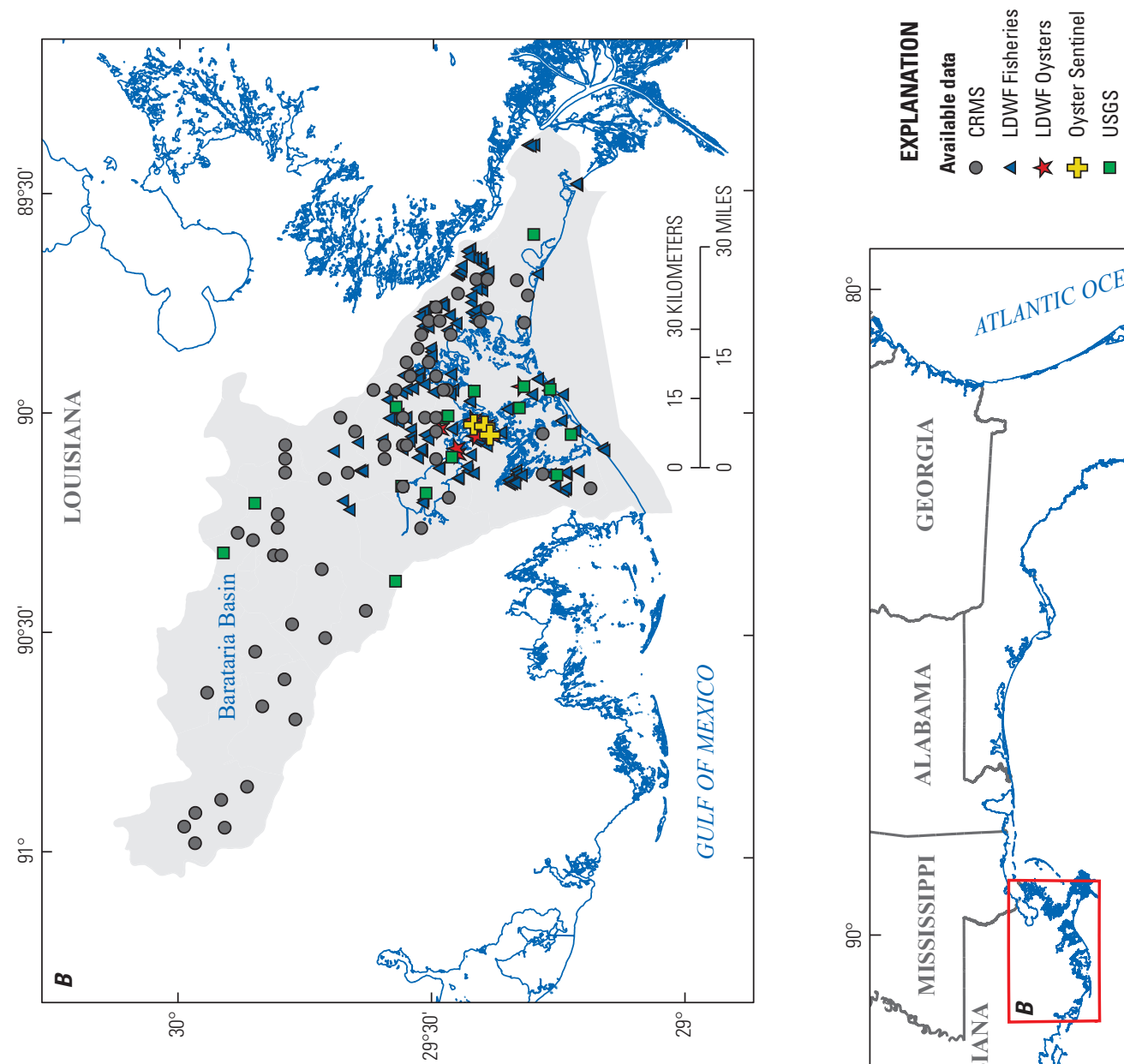

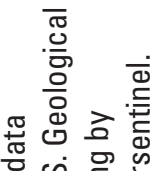

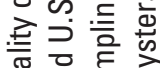

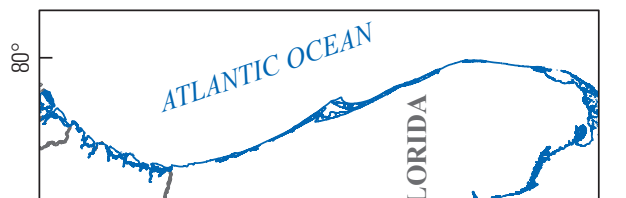

政

市令要

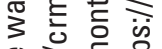

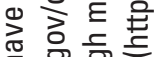

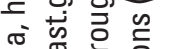

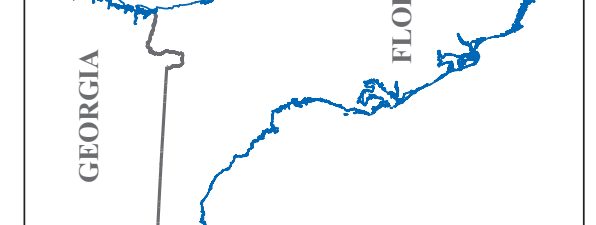

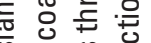

क

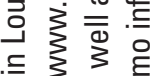

政

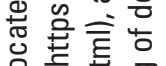

을 을

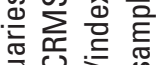

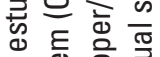

产离离

के के है

ब웜

을

䙲

ஃ
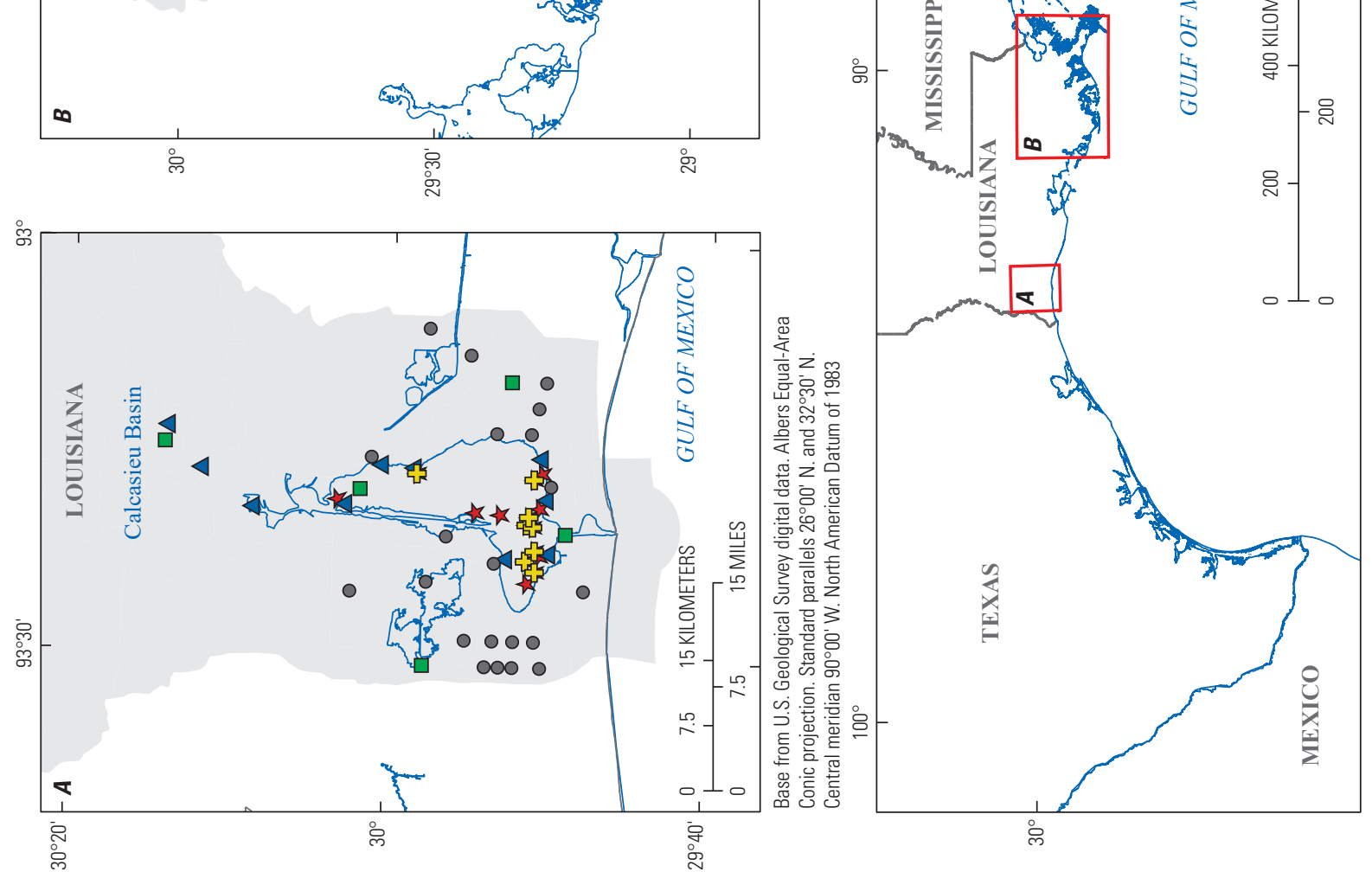

옹 $\sum_{0} \frac{\pi}{0} \frac{t}{0}$

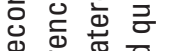

닌

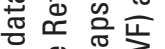

छ 을 蛋

矛

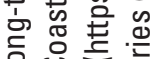

의

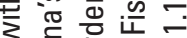

क 흥 흥 응

号券

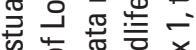

d 0 응 흔

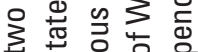

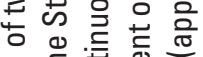

응

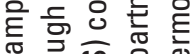

匹

山 월

능르음

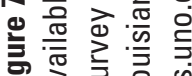


within the region of interest. In order to demonstrate that these models are fairly ubiquitous, although not always publicly available, we provide a nonexhaustive list of numerical 2D and 3D models by estuary (appendix 2, table 2.1). This list largely includes those models coupled to oyster models identified in the Oyster Model Inventory section, along with some examples published in the literature since 2010. In addition, numerous generic, 3D hydrodynamic models are available for application to coastal oceans and estuaries. These include, but are not limited to, the Princeton Ocean Model (POM; Blumberg and Mellor, 1987), the semi-implicit Estuarine and Coastal Ocean Model (ECOM; Blumberg and Mellor, 1987), the Finite Volume Community Ocean Model (FVCOM), and the Regional Ocean Model System (ROMS; Haidvogel and others, 2000).

In addition to models already used in oyster-specific modelling, water resource and ecological restoration projects have multiple 2D and 3D numerical models available for evaluation of water flow, salinity, turbidity, nutrients, and chlorophyll $a$ in the Gulf of Mexico estuaries. Examples of such models include the Adaptive Hydrodynamics Model (AdH), the Delft modeling platform, Environmental Fluid Dynamics Code (EFDC), South Florida Water Management Model (SFWMM), and Water Quality Analysis Simulation Program (WASP). These models are often developed by engineering firms in partnership with State and Federal agencies for use in environmental assessments and impact statements to support litigation and evaluate operational scenarios from reservoirs and lakes, levee projects, Mississippi River diversions, and coastal restoration projects. For example, 2D and 3D numerical modeling of rivers, lakes, and coastal areas using 3D EFDC hydrodynamic and water-quality models of Caloosahatchee River Estuary, Apalachicola Bay, Suwannee River Estuary, and Perdido Bay in Florida have been developed and used for alternatives analyses and for litigation support (for example, Bales and others, 2006; and DSLLC, 2007, 2008, 2009).

Coastal engineering firms that develop similar hydrodynamic and water-quality models are located throughout Gulf of Mexico coastal States; however, the model source codes or executable versions used in previous studies likely vary in availability, as many of these models are considered proprietary and thus not publicly available. In such cases, the authors of the modeling report or the supporting agency should be contacted to request the modeled results from the study or to inquire about whether the model program version and data files are available to run the model for oyster model inputs and drivers. This will be the case with most of the modeled data available for the estuaries (for example, table 2.1). The model source code and either the modeled data or the model executable versions and input files needed to run the models will have to be requested from the model developers or the agencies that supported the respective works. If there is interest in obtaining specific modeled data for certain estuaries as inputs to oyster models designed for identifying broodstock or sanctuary reef sites and metapopulation dynamics, then it is important to understand the extent to which the hydrodynamic model has been calibrated and validated for the system, if at all, in order to understand the level of accuracy and uncertainty in the modeled physical and water-quality data, and how these modeled environmental data inputs can affect the coupled oyster models.

More recently, in some regions, satellite derived data have become increasingly accessible for extrapolating key water-quality parameters, such as temperature, salinity, turbidity, and chlorophyll $a$, through platforms such as Google Earth Engine. Use of these data can sometimes be complicated for inshore and estuarine areas, and for areas with large river inputs, data extraction performs more poorly where coastal processes dominate (because of high chlorophyll $a$ and sediment resuspension).

Summary-

- Continuous data recorders, long-term monitoring programs, and hydrologic, hydrodynamic, and water-quality models creating modeled "data" provide a range of available data to use as drivers in oyster models for Gulf of Mexico estuaries.

- Many parameters are available across the majority of the estuaries of interest; significant variability exists in the temporal and spatial coverage of the data, which may impact the ability of oyster models to provide outputs at appropriate spatial or temporal scales for management purposes, or may result in ecological, water-quality, or physical data inputs with limited calibration or validation.

- Coordinated, spatially distributed continuous data recorders and long-term monitoring programs to collect water-quality, ecological, and physical data across the region would inform models useful for site selection for restoration of a network of reefs.

\section{Oyster Model Inventory}

Over the last few decades, numerous models designed to help inform the management and restoration of oyster resources have been developed across the range of the eastern oyster. Here, we provide results from a literature review of eastern oyster modeling, including peer reviewed and grey literature, and summarize model details (appendix 3, table 3.1). The oyster models have been classified into four approaches for evaluating oyster resources in the Gulf of Mexico: (1) oyster Habitat Suitability Index (HSI) models; (2) larval transport models; (3) on-reef oyster models that may include oyster growth, mortality, and reproduction; and (4) coupled larval transport and on-reef metapopulation models that simulate the entire oyster life cycle (table 3.1, fig. 8).

The data types and resolution needed for each modeling approach, construction, calibration, and validation differ. A metapopulation modeling approach simulates the entire oyster 
life cycle, accounting for the on-reef oyster growth, mortality, and reproduction to estimate oyster density and (or) biomass, size distribution, and spawning; and larval transport (with behavior and sometimes with growth and mortality) to output recruitment or spat settlement on reefs (fig. 8).

The primary water-quality drivers affecting on-reef oyster processes are salinity and temperature, with dissolved oxygen and food availability being secondary in importance. The ecological drivers of oyster mortality are predation and disease, and these are often implicitly accounted for in the salinity and temperature effects. Current velocities and water depth are physical drivers affecting the reefs (fig. 8). The list of models in table 3.1 covers most, but not necessarily all, studies for the Gulf of Mexico that were publicly available in journals, books, and technical reports. A small portion of the listed models are in progress or were supplied by the agencies as draft reports (for example, Lindquist and others, 2021); there are likely other unpublished and ongoing works that we were not aware of at the time of this report; however, the listed examples in table 3.1 cover the full list of model inputs, outputs, processes, and spatial and temporal considerations that are common across modeling studies. Spatially explicit frameworks for all four oyster modeling approaches have been applied, either by creating and integrating GIS spatial data layers or by coupling 2D and 3D hydrodynamic and water-quality models, for evaluation of the spatiotemporal drivers and effects of changing conditions on oyster resources. Figure 9 demonstrates which of the four modeling approaches have been developed, calibrated, and (or) validated for the Gulf of Mexico estuaries.

Here, we discuss how applicable or transferable each of the four modeling approaches are toward siting oyster broodstock reefs across Gulf of Mexico estuaries based on the literature, expert opinion of the data availability, the current state of knowledge of oyster thresholds and responses to environmental conditions, and the accessibility and ease of use of the modeling software or programs. The data requirements, model complexity and assumptions, and transferability vary by approach. The tradeoffs related to data availability, model

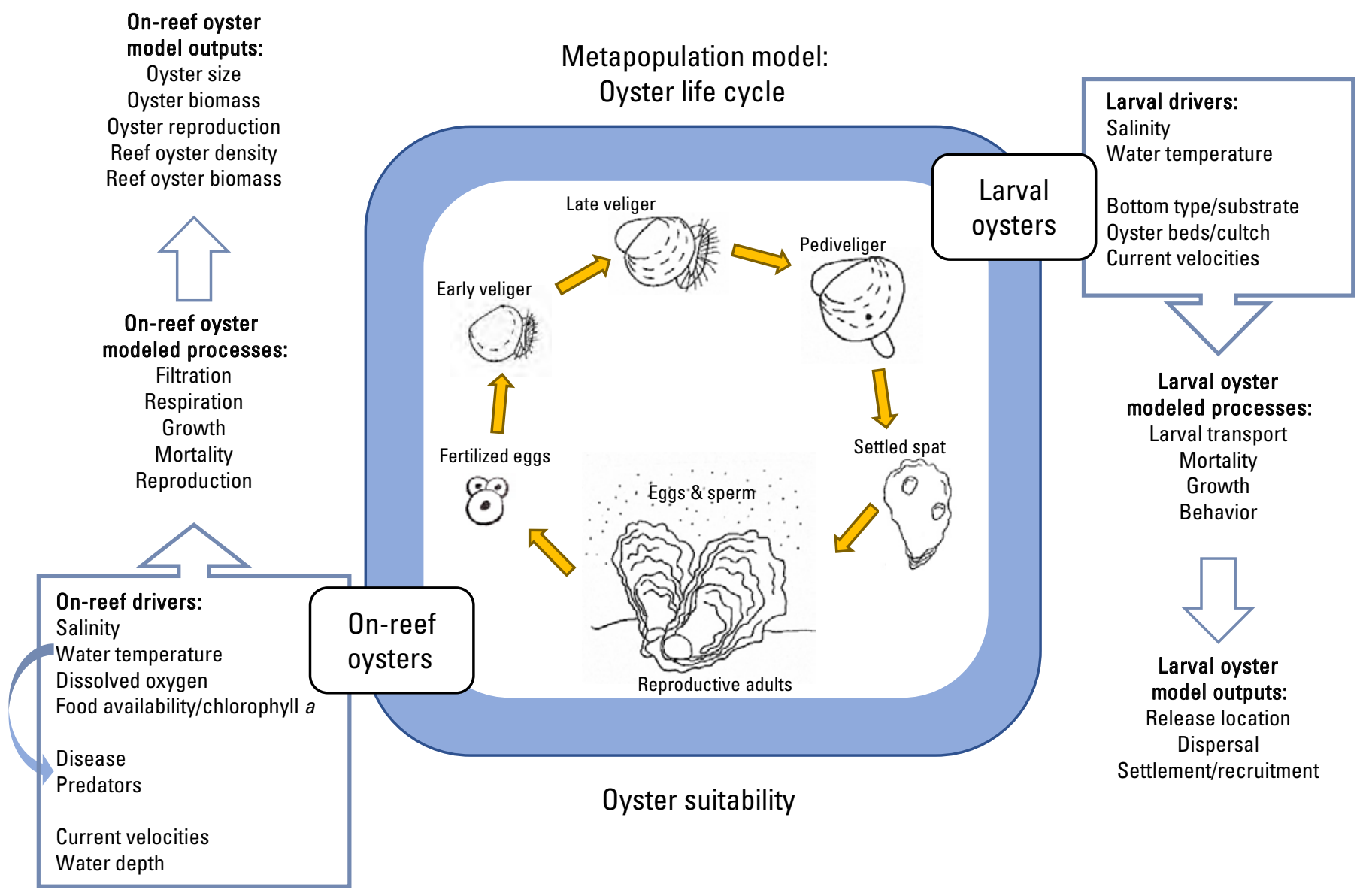

Figure 8. Drivers and outputs of models capturing larval transport, on-reef population dynamics, and metapopulation models that simulate the entire oyster life cycle, coupling larval and on-reef population dynamics models. Oyster suitability models can encompass any part of the entire oyster life cycle to account for various oyster life stage processes and the interaction with drivers to output oyster habitat suitability. This figure identifies the most commonly used water-quality (salinity, water temperature, dissolved oxygen, and food availability), ecological (disease and predation) and physical drivers (current velocity, water depth, and oyster bed/cultch) for these four modeling approaches, and identifies common model outputs. Oyster spat may settle on the same reef as parents but are equally or more likely to settle on other reefs because of larval transport. 


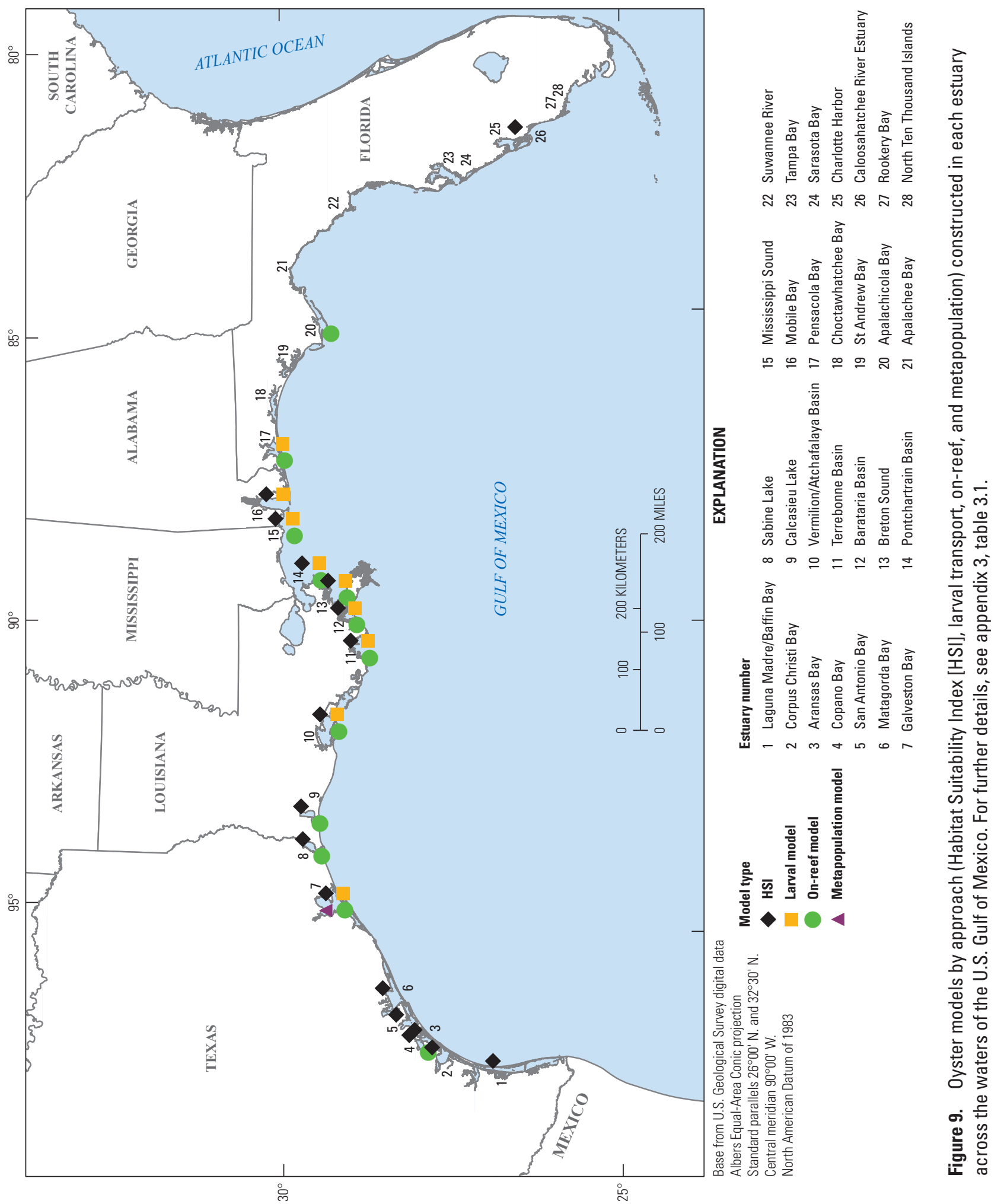


complexity, and flexibility or transferability impact selection of a modeling approach. Specifically, some approaches may offer greater accessibility, flexibility, and transferability spatially or temporally, with minimal data input, but could only provide broad information to support site selection. In contrast, other approaches may require significant site-specific data for their construction and validation but may provide more accurate and location-specific data to support site selection for broodstock reefs.

\section{Approach 1: Geospatial Habitat Suitability Index}

Oyster suitability models usually encompass the entire oyster life cycle to describe suitable oyster habitat based on the water-quality, ecological, and physical drivers (fig. 8), but the effects on oyster life stage processes are implicitly accounted for within simplified habitat suitability functions or indices. The HSI model is the most widely applied modeling approach for oyster restoration planning across Gulf of Mexico estuaries and coastal regions (fig. 10). HSI modeling is a simplified and highly flexible approach widely used by resource agencies (for example, USFWS, 1981; Brooks, 1997; Roloff and Kernohan, 1999; Lindquist and others, 2021) for evaluating how water resource and ecological restoration projects affect habitat suitability for a species. HSI models describe the suitability or capacity of a given area or region to support a species based on multiple overlapping physical and water-quality parameters within the given area. Numerous HSI models have been built and are currently used by restoration and management agencies, as the models can be applied across different spatial scales, have inputs that can occur across different temporal scales, and include predicted impacts of proposed activities.

Each component Suitability Index (SI) within an HSI model describes the suitability (typically between 0 and 1 , where 0 is defined as uninhabitable and 1 is defined as optimum habitat) for supporting the species as a function of the input variables, and then the overall HSI score is calculated as the geometric mean of the number $(n)$ of SI included within the overall equation as

$$
H S I=\left(\prod_{i=1}^{n} S I_{i}\right)^{1 / n} .
$$

The common independent variables for determining oyster suitability were originally formulated by Cake (1983) and first field tested in Galveston Bay by Soniat and Brody (1988). For most of the HSI models listed in the oyster model inventory, the SI relationships originally described by Cake (1983) and Soniat and Brody (1988) are either used directly or have been modified to describe the local patterns in oysters and environmental conditions (see "Model input variables" column, table 3.1). The SI variables commonly included in the Gulf of Mexico HSI models are the area of hard substrate to capture potential areas for spat settlement and available reef areas, and the monthly, annual, and historical salinity means and minimums to capture conditions necessary for oyster survival, growth, and reproduction. Other SI relationships that have been developed and used in HSI models include those for the following: bottom dissolved oxygen (DO), turbidity, or TSS concentration, which can affect oyster filtration; water depth, which is also used as a proxy for bottom DO; frequency of high river flow or killing flood events within a given year; substrate types that permit or preclude larval settlement; and monthly sediment accretion rates that can preclude larval settlement and depress oyster feeding (table 3.1; fig. 10; for example, see Battista, 1999; Barnes and others, 2007; Starke and others, 2011; Linhoss and others, 2016; Lindquist and others, 2021). The lack of inclusion of these parameters in many of the HSI models is due to the limited availability of water-quality data.

Other data, including ecological data, and logistical variables have been incorporated into HSI models. For example, Beseres Pollack and others (2012) incorporated SI functions for dermo infection or the prevalence of Perkinsus marinus affecting oyster mortality in Texas estuaries. Puckett and others (2018) and Theuerkauf and others (2019) HSI models for a North Carolina estuary incorporated an extensive list of 17 environmental, biological, and logistical SI variables to be used in their oyster reef restoration programs, which were derived from stakeholder meetings. Their list of logistical variables includes factors such as proximity to the material stockpile site and nearest boat ramp.

HSI models have been developed, calibrated (Beseres Pollack and others, 2012; Swannack and others, 2014), and validated by comparing projected oyster HSIs to spatial oyster density data collected over reefs (Theuerkauf and Lipcius, 2016; Puckett and others, 2018; Reisinger and others, 2020) for use in oyster reef restoration planning and evaluation. These geospatial HSIs have been developed using GIS software to create spatial layers of summarized environmental data for time periods important to oyster life history (for example, spawning salinity, mean annual salinity). The environmental data used for creating the GIS input layers include spatially interpolated point data from water-quality monitoring and bottom surveys by agencies such as NOAA and the Texas Parks and Wildlife Department (TPWD), satellite data, and data generated from $2 \mathrm{D}$ and $3 \mathrm{D}$ hydrodynamic and waterquality models available for the regions (see "Timeframe and sources for input data in modeling study" column in table 3.1, and tables 1.1 and 2.1). The geospatial approach involves outputting the SI score for each environmental variable layer, as well as an estimate of the overall HSI, for each grid cell within the GIS map, to produce the spatial oyster suitability scores from 0 to 1 over the time period(s) represented by the data layers. Nearly all of the geospatial HSI studies listed in table 3.1 performed sensitivity analysis of the input parameters to determine which of the environmental variables the oyster HSI is most sensitive and least sensitive to in the system (Beseres Pollack and others, 2012; Swannack and others, 2014; Puckett and others, 2018, Theuerkauf and others, 2019). 

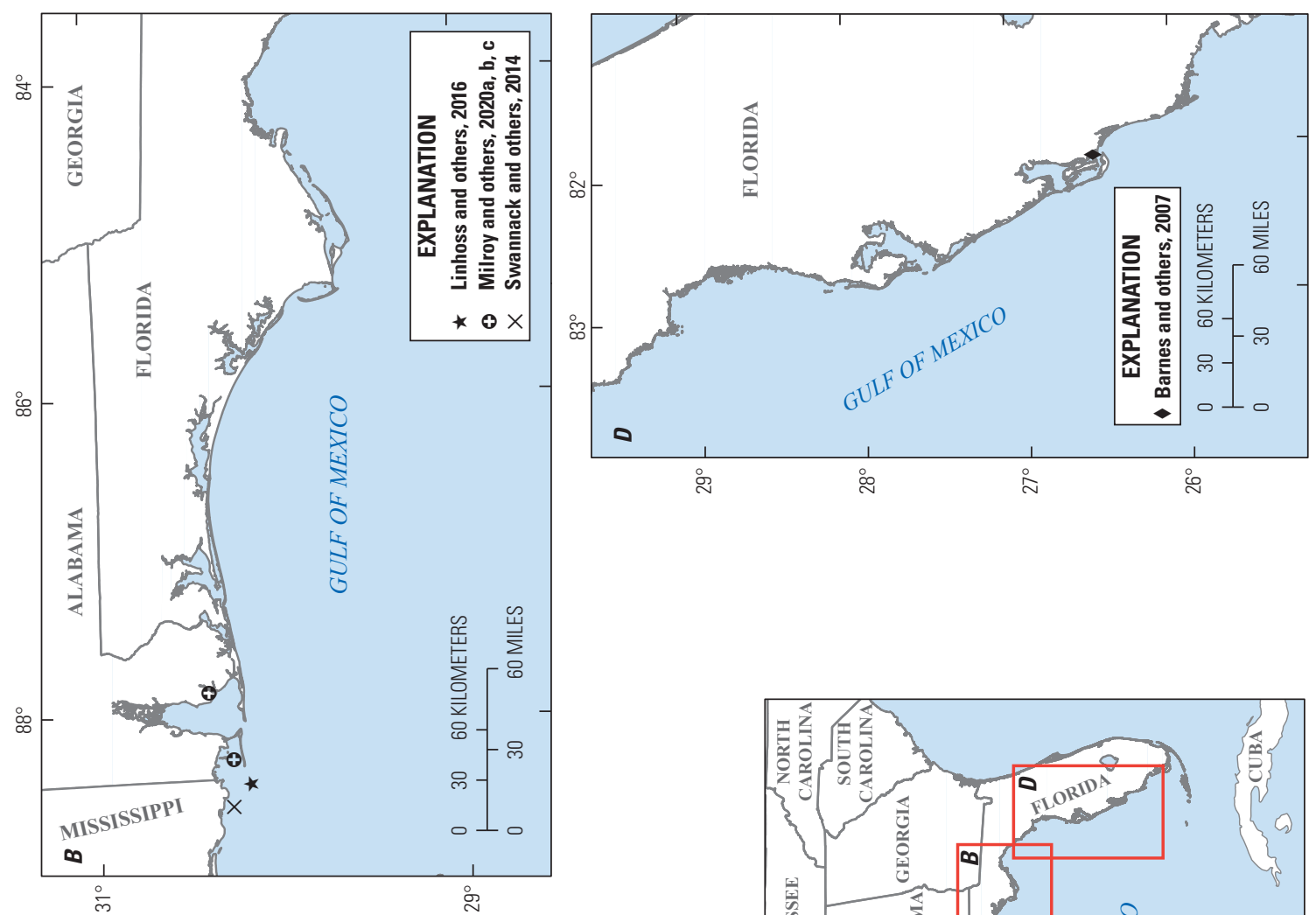

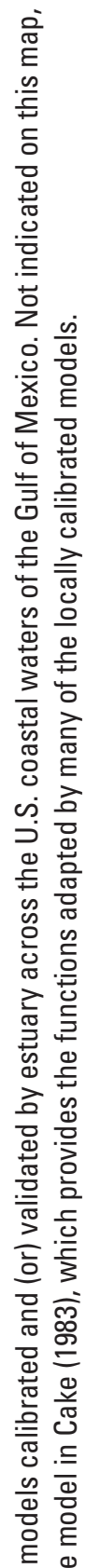
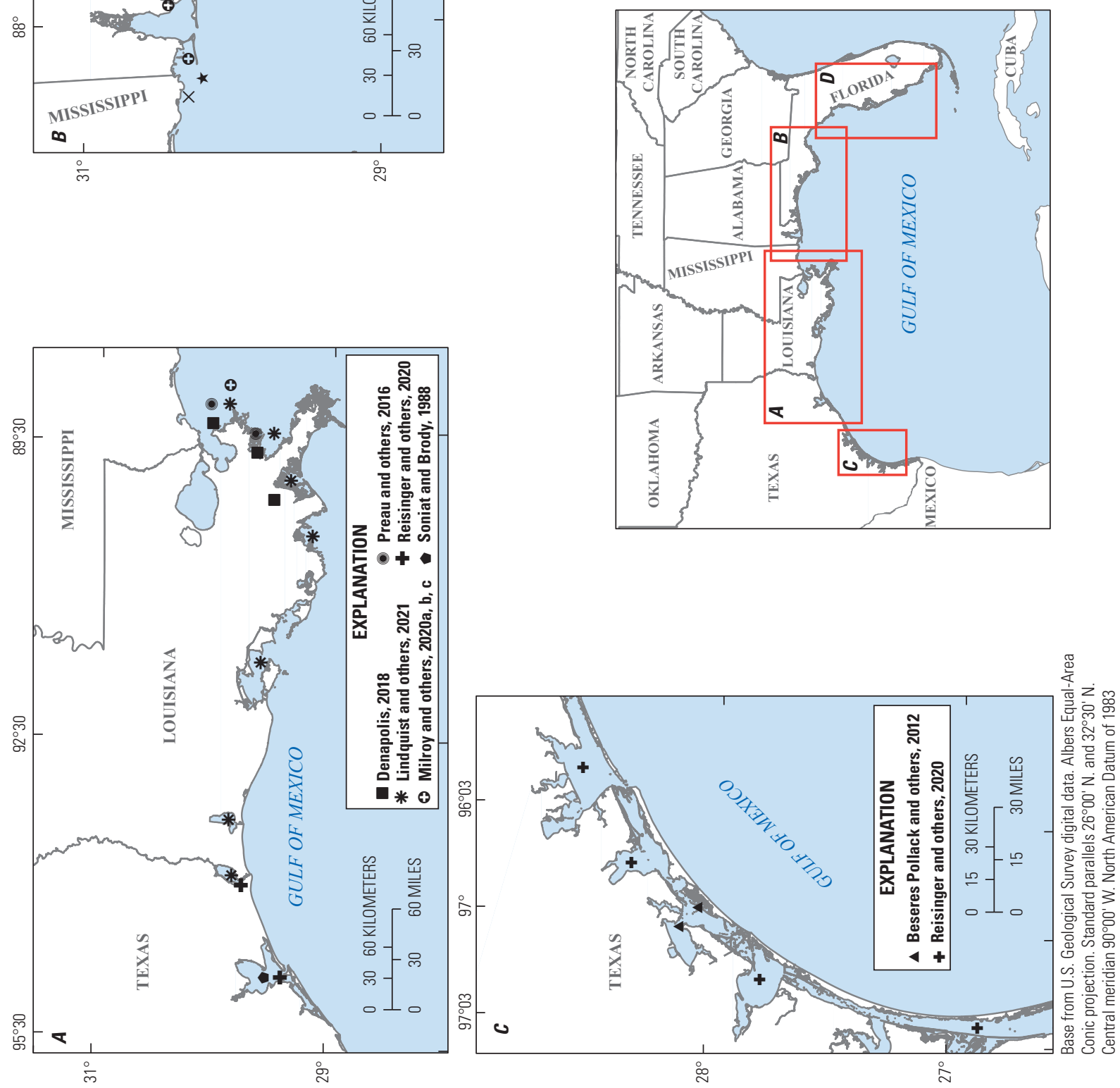

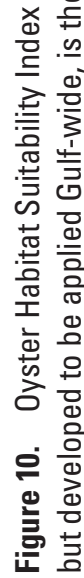


One developing approach, different than the static geospatial grid most commonly used, follows a Lagrangian methodology whereby a larval oyster HSI is computed according to the cumulative exposure to salinity and temperature gradients in space over time. This larval suitability score provides an estimate of larval oyster condition from spawning to settlement (Milroy and others, 2020a, b, c; see "Larval Transport Modeling" section below; table 3.1).

The geospatial HSI models are also referred to as the Oyster Suitability Index (OSI) models or the Reef Suitability Index (RSI) models in the listed studies. This modeling approach has also been used to quantify and model reef quality and ecosystem services. For example, Beseres Pollack and others (2012) developed the Reef Quality Index (RQI), which used oyster monitoring data from TPWD to evaluate and compare the current health or quality of existing reefs for MissionAransas Estuary in Texas. Theuerkauf and others (2019) created the Ecosystem Service (ES) index for Pamlico Sound, North Carolina, by building off of the oyster HSI for the same region (Puckett and others, 2018), to determine where water filtration services could be enhanced within the sound by incorporating data on chlorophyll $a$, water flow, and DO.

\section{Summary-}

- HSI models describe the suitability of a location to support oysters based on environmental data and oyster tolerance and thresholds to specific physical and water-quality parameters.

- Cake (1983) provided the first framework for development and use of this approach; since then, numerous HSIs have been built and are used to assess management and restoration actions.

- HSIs are widely available, flexible tools for determining optimal oyster habitat for restoration, can be rapidly developed, and are easy to integrate into GIS products.

- HSIs provide only broad suitability functions based on limiting sensitivity to changing environmental conditions, do not deal with complex environmental interactions, and would benefit from investment in examining larval suitability to estimate larval survival and inform reef recruitment.

\section{Approach 2: Larval Transport Modeling}

Larval transport models describe larval transport, dispersal, and recruitment to settlement (fig. 8). These models are primarily driven by current velocities and incorporate larval movement behavior, and in some instances, models of larval growth and mortality in response to salinity and water temperature. Larval transport modeling provides information to support site selection related to potential connections of oyster populations or individual reefs. As our understanding of oyster metapopulations and genetics increases, understanding the movement of larval resources and connectivity of oyster reefs remains important. For a reef to serve as a broodstock reef, it must provide larval resources to other reefs. This entails ensuring a reef or potential reef site supports a reproductive population (that is, a source reef), and ensuring that any oysters spawning on the reef provide resources to outside reefs or proposed reef locations (that is, sink reefs). Larval transport modeling examines the second part of this requirement. Larval transport models remain limited (fig. 11), as they are difficult to validate and are intrinsically dependent on the state of existing fine-scale hydrodynamic models and their ability to resolve particle transport for the area of interest. Such models require a better understanding of larval movement, tolerances to water-quality conditions, and vulnerability to predation.

Oyster larval transport modeling is based on the particle-tracking module of a hydrodynamic or estuarine circulation model, with the addition of larval vertical migration behavior to help the larval particle maintain or change its position in the water column. Larval transport models simulate physical transport at relatively fine spatial resolution using the current velocities and directions generated by the hydrodynamic models at very short time steps (for example, hydrodynamic models often run on the order of 15-30 seconds). Larval growth and survival as a function of salinity, temperature, turbidity, and predation mortality have been added as biological components to the individual particles (for example, Dekshenieks and others, 1993, 1996, 1997, 2000; Puckett and others, 2014), and have been included in some form in other oyster larval transport models (for example, Kim and others, 2010, 2013; Arnold and others, 2017; Milroy and others, $2020 \mathrm{a}, \mathrm{b}, \mathrm{c})$. The size classes of larvae in the model have different survival rates, primarily determined by predation mortality pressure at different salinities and (or) depths. Dekshenieks and others (2000) provides the most complete example, and includes larval growth and size- and depth-dependent behavior based on predation mortality in the larval transport modeling component of their full life cycle metapopulation approach for Galveston Bay (see "Metapopulation Models" in table 3.1, fig. 11).

Larval transport models start with the simulated release of many larval particles from single to several initial locations within the model domain. Initial location and day of release are recorded for each particle. There can be multiple release dates for locations, depending on the length of the simulation. Larval particle positions are generally tracked, on the time scale of minutes, over 20 to 60 -day simulations that cover the oyster spawning periods and simulated seasonal currents and conditions. Daily larval particle position and age (in days), and sometimes size (for example, Dekshenieks and others, 2000), are tracked until successful settlement on suitable substrate occurs, or else the particle fails to successfully settle on the defined suitable substrate. A particle may fail to settle and die if larval particles are flushed out of the system by currents, or else fail to be transported to defined areas with hard substrate within the larval stage duration (typically 

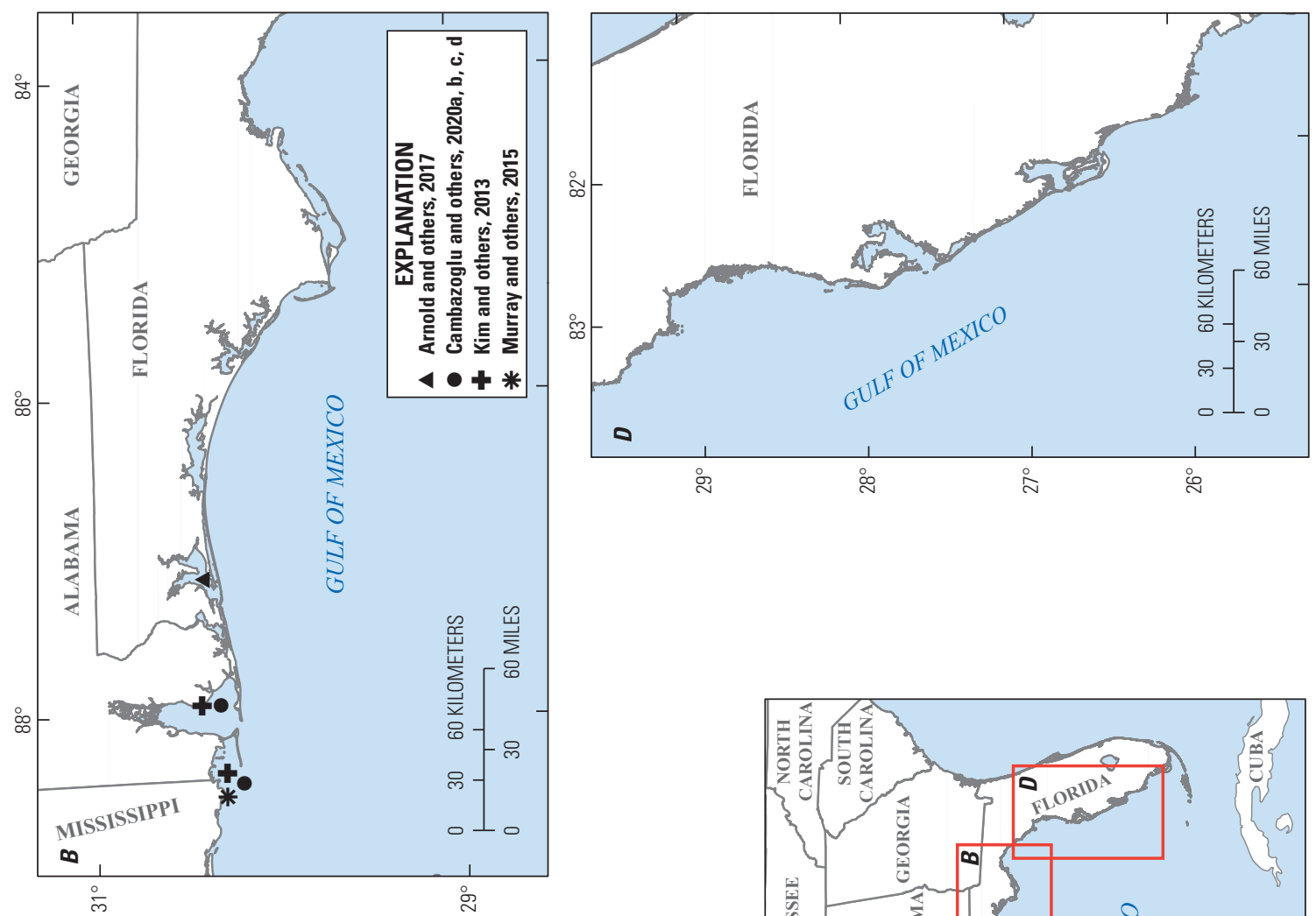

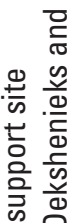

으.

들

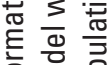

을 응

능

을 ‘

읶즘

可 즈 짐

을 즈

능 号

을 ญ
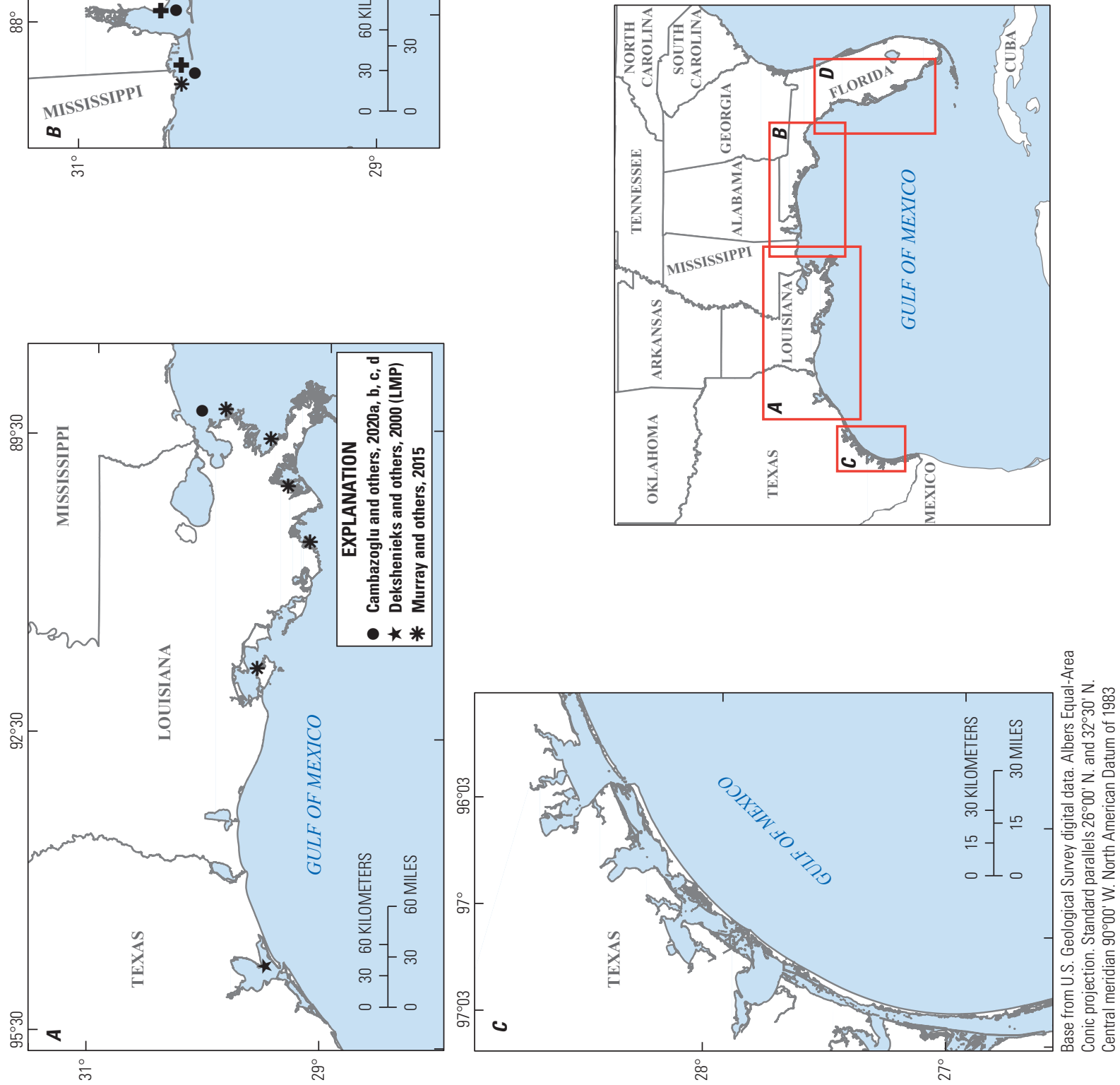

흏

전

도 온 응

य $\frac{\omega}{\pi}$

克 豆

凹

. ํㅡㄴ

$\sum^{0} 0$

눙 에는

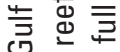

$\leqq \overline{0}$

웡 윽 음

흥 흥 흠

गั

든 ธั

它 芫

屯 흠

은은 엉

突 㐫

ฮั่ ठิ

응 눅

힘 등 응

능 엉

응 등. 소

E

흥 몰

कํํํํㅇ

흔 응

휴 윰

宁兽.

홍ㅇㅇ

트응ㅇㅇ

竞总离 
about 21 days). Processed larval transport model outputs from a simulation include mean age at settlement, percentage of successful recruitment based on release date and natal reef site (initial location), and connectivity matrices that describe the proportions released and settled among the multiple reefs.

Difficulties with measuring larval survival and dispersal in the field impede validating predictions, including dispersal paths, distances, settlement distribution, and percentage of successful recruitment. In reality, these difficulties in field measurements are what led to the development of biophysical models (Metaxas and Saunders, 2009). Regardless of these difficulties, the use of these models to predict larval transport or assess oyster population connectivity are increasingly called for in support of oyster management (table 3.1, fig. 11); the development of better tools to build datasets enabling model validation would help ensure larval transport models accurately reflect larval condition and transport. One such work in progress that may help improve current understanding of larval condition and dispersal paths is that by Milroy and others, 2020a, b, c (table 3.1), which involves determining larval oyster habitat suitability within the water column for coastal drifters, as they indicate potential passive transport and dispersal pathways in coastal waters.

One of the most well documented oyster larval transport models was developed for the Chesapeake Bay and has been used in the development of other larval transport models (North and others, 2008). This estuary-wide oyster larval transport model linked the Regional Ocean Modeling System (ROMS) hydrodynamic model, a particle-tracking model with larval behavior (LTRANS), and a settlement submodel identifying suitable substrate bottoms. Oyster larvae movement was tracked over 14-21 days and predicted final reef settlement locations. The substrate submodel determined whether suitable substrate existed at the final settlement location. Differences in larval growth or predation mortality were not considered, but larval particles died and were removed from the model if they failed to encounter suitable habitat within the 14-21-day larval period.

Five biophysical models described in recent literature are used to evaluate oyster larval retention, dispersal, and settlement among existing reef networks within estuaries of the Gulf of Mexico (table 3.1, fig. 11). These include a report prepared for the Deepwater Horizon NRDA Oyster Technical Work Group (Murray and others, 2015), and ongoing works by Cambazoglu and others (2020a, b, c, d) in the Mississippi Sound and Bight, summarized by the Gulf of Mexico Research Initiative GRIIDC site (for further reading, see https://data. gulfresearchinitiative.org/). Aside from those two technical reports, Kim and others (2010) and Arnold and others (2017) describe their respective biophysical models of Mobile Bay and eastern Mississippi Sound, and the Pensacola Bay System in Florida. Kim and others (2010), Murray and others (2015), and Arnold and others (2017) provide larval transport studies that include validation with field data for larval concentrations; Kim and others (2010) and Arnold and others (2017) further include spat settlement, larval growth, and mortality. Kim and others (2010) simulated larval transport by tracking larval concentrations within an EFDC hydrodynamic and eutrophication model over 215 days from April through November 2006 (Kim and others, 2010, Kim and Park, 2012). This model was used to determine if spawning locations and physical conditions affected transport and retention in Mobile Bay (Kim and others, 2013). This model was further used to assess the impacts of a proposed closure of a cut in a barrier island on oyster survival and larval retention in the bay (Park and others, 2014). Arnold and others (2017) used a coupled biophysical model of the Pensacola Bay System based on water currents generated from the Estuarine Coastal Ocean Model (ECOM) to drive larval transport over 20-day simulations from May 2007 through July 2008. Arnold and others 2017 used the model to hindcast larval dispersal patterns and settlement data collected among existing reef stations during four discrete 20-day events across different years.

Implementing larval transport models across Gulf of Mexico estuaries requires significant investment in field validation of the models by collecting larval concentrations, spat settlement and estimating larval survival. These field data are difficult to collect and interpret, and are often only used to try to validate larval transport modeling. For example, the larval oyster HSI model in progress (see Milroy and others, 2020a, b, c, in table 3.1) used modeled coastal drifter tracks to represent passive larval oyster transport coupled to salinity and temperature fields generated by the Coupled-OceanAtmosphere-Wave-Sediment Transport (COAWST) model (Cambazoglu and others, 2020a, b, c, d). The larval oyster HSI model was then validated with ground-truthed water-quality data for the Mississippi Sound region to estimate oyster suitability scores along the tracks, providing an idea of whether oyster larvae could survive. The use of actual or modeled coastal drifters (Cambazoglu and others, 2020a, b, c, d) for validating transport and trajectories, along with more targeted field monitoring of larval oyster concentrations and spat set, are required for model validation. Additionally, an improved understanding of oyster fecundity (Hofmann and others, 1994) and better monitoring of oyster reproductive events related to water-quality changes on daily time-scales are required.

Summary-

- Oyster larval transport models combine hydrodynamics and larval movement and survival to explore potential connections between existing (or planned) oyster reefs.

- Several existing larval transport models described by North and others (2008), Kim and others (2010, 2013), and Arnold and others (2017) provide well documented modeling designs and studies to build on.

- Knowledge about oyster larval transport is essential both to understand reef connectivity across a network of reefs and to support the expansion of management beyond single reefs to a network of reefs.

- The lack of understanding about larval behavior, growth, and survival under a range of conditions, and availability of fine-scale hydrodynamic models with particle transport limit the availability and development of larval models. 


\section{Approach 3: On-Reef Oyster Growth, Mortality, and Reproduction Modeling}

On-reef models represent and evaluate on-reef oyster population vital rates or processes such as filtration, growth, mortality, and reproduction with changing environmental and biological drivers (fig. 8). The approaches commonly used are (1) a mechanistic, bioenergetics methodology using dynamic energy budget (DEB) theory, and (2) size-structured population modeling to describe filtration, growth, mortality, and reproduction for the oyster size classes. Several such models have been developed, calibrated and (or) validated for some Gulf of Mexico estuaries (fig. 12). These models critically inform oyster reef development, relying on our understanding of settled oyster responses to environmental conditions, but lack information linking adult populations to new recruits. More recently, based on the recognized need for oyster reefs to maintain their own substrate over time (which is based on recruitment, growth, and mortality providing new shell and substrate), models that incorporate reef persistence have been developed and include a shell budget model (SBM; Soniat and others, 2012a, 2014) and an individual based model (IBM) using a coupled DEB model with a shell budget model to simulate 3D oyster reef structural mechanics, and individual density, biomass, and maintenance (Yurek and others, 2021).

The mechanistic, bioenergetics approach used is based on the DEB model created for the eastern oyster in the northern Gulf of Mexico (Lavaud and others, 2017). This approach simulates daily energy densities and flux rates using bioenergetics-based filtration, assimilation, and respiration rates for somatic and reproductive growth of an oyster individual over a given year. Lavaud and others (2017) used daily temperature, food availability, and salinity as forcing variables on oyster filtration and respiration rates to project daily growth and reproduction over a given year. The authors calibrated oyster shell height, tissue, and gonadal dry weight with two reef sites in Louisiana, and then validated oyster shell height and dry weights for six reef sites across the Gulf of Mexico. This mechanistic, bioenergetics approach could be particularly useful in evaluating how changing environmental conditions would affect the spatial distribution of oyster growth on reefs (Lavaud and others, 2021). In Canada, Filgueira and others (2014) used a DEB for oyster growth coupled with a nutrient-phytoplankton-zooplankton-detritus (NPZD) model driven by temperature, current velocities, and water depth from a hydrodynamic model. This model was used to evaluate oyster-phytoplankton interactions and oyster carrying capacity for three areas across an estuary. The coupled models were used to explore the growth of oysters to variation in environmental conditions and stocking scenarios for the reefs. This coupled bioenergetics-NPZD modeling approach is an example that demonstrates how the outputs from hydrodynamic/ water-quality models could be used as inputs into a DEB model to generate predicted changes in oyster growth among different reefs.
The earliest models involve modeling oyster reefs using size-structured population models to describe filtration, growth, mortality, and reproduction for the oyster size classes (that is, Powell and others, 1992, 1995, 1996, 1997, and Hofmann and others, 1992, 1994). The original models, developed in the 1990s for Galveston Bay, were size-structured oyster reef population models comprising 11 size classes to simulate daily changes in oyster biomass and size structure caused by daily variation in salinity, temperature, food availability (chlorophyll $a$ ), current velocities, water depth, and turbidity affecting oyster filtration, respiration, somatic growth, reproduction, and mortality (mortality caused by weather extremes, and implied Perkinsus marinus and predation mortality). The size-structured reef population is a single point model that was later applied to simulate multiple reef population point models within a hydrodynamic model grid of Galveston Bay. Although no formal calibration or validation of the reef population models were noted in the publications, the initial oyster densities and size distributions were set from field study data collected on the Galveston Bay reefs.

More recently, Wang and others (2017) used a size-structured oyster reef population approach to examine impacts of changes in freshwater flow and relative sea level on weekly and annual oyster reef growth across Breton Sound, Louisiana. This model was modified from the original oyster model developed through the Powell and Hofman studies in Galveston Bay (Powell and others, 1992, 1995, 1996, 1997, and Hofmann and others, 1992, 1994), and previously applied to Apalachicola Bay (Wang and others, 2008). The model simulates key growth processes (for example, ingestion, assimilation, respiration), mortality, and reproduction, and was coupled with the three-dimensional Delft FLOW (D-FLOW) and Delft water-quality (D-WAQ) models to examine the spatiotemporal effects of changes in freshwater flow, sea level, temperature, salinity, turbidity, and food availability on spat, seed, and sack size classes. The simulations demonstrated how oyster reef production changed in magnitude and shifted throughout Breton Sound based on the combinations of low and high sea level rise and freshwater diversion flows.

Soniat and others (2012a, 2014) developed a shell budget model (SBM) focusing on overall reef sustainability with a benchmark goal of ensuring no net loss of shell within restored or harvested reefs. This work derives from discussions related to goals of maintaining oyster abundance and shell to ensure reef sustainability (for example, Mann and Powell, 2007; Klinck and others, 2002; Powell and others, 2009; Powell and others, 2012). The SBM emphasizes the sustainability of substrate as the most economically advantageous goal within the Gulf of Mexico and its high intra-annual variation, which precludes the use of standard biological reference points and highlights that substrate maintenance is a function of both oyster abundance, growth, mortality, and shell loss that can vary between years. The SBM provides a numerical model that uses annual stock assessments of oyster density and size inputs, and simulates oyster growth and mortality and natural shell loss to 

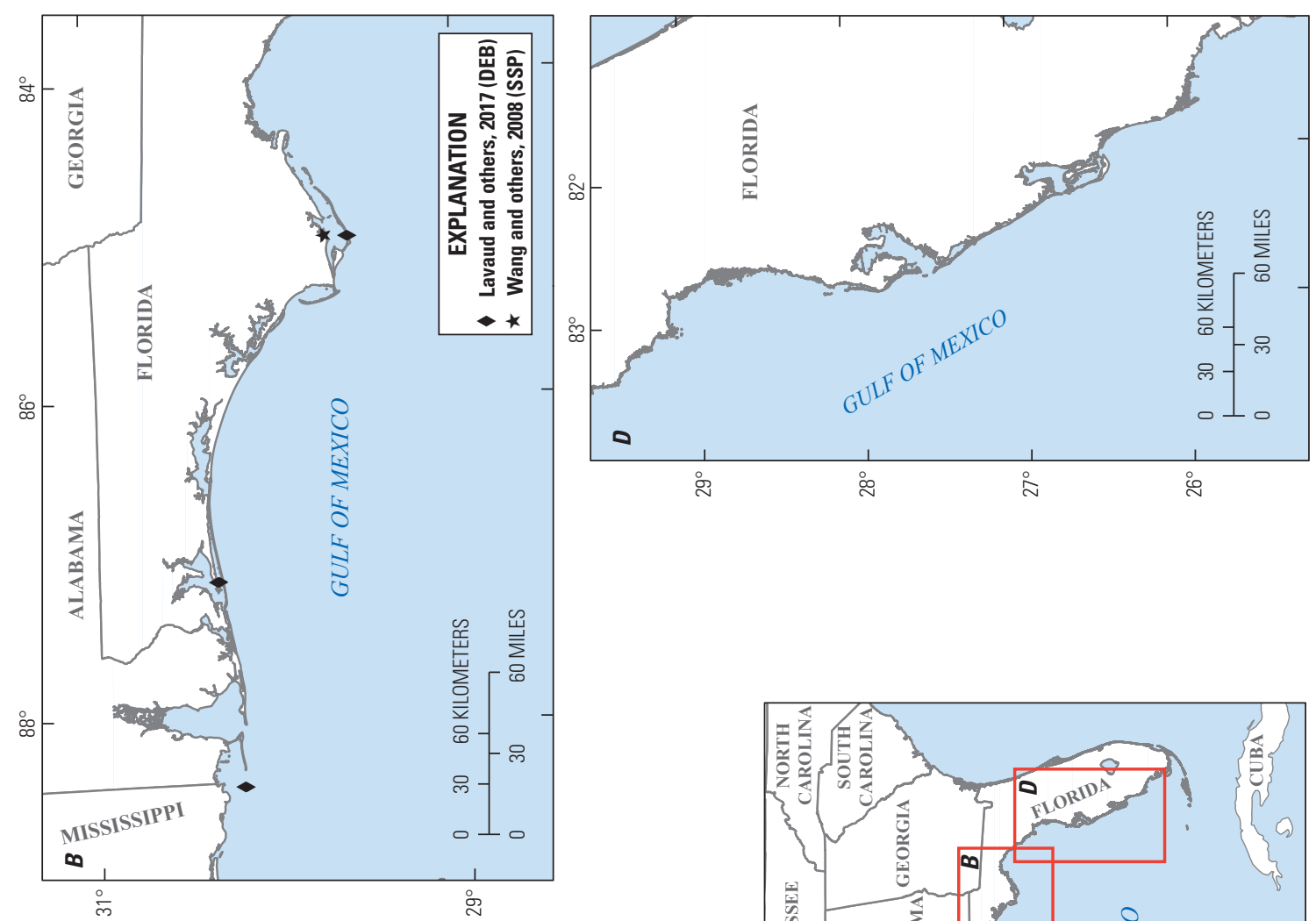

을 总

坖离

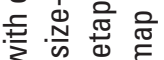

ธิ

尊

응 웡ㅎㅁ

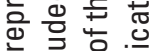

은

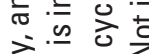

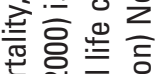

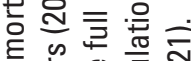

E ⿻上丨。

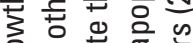

는 믄

元

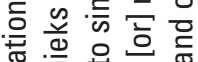
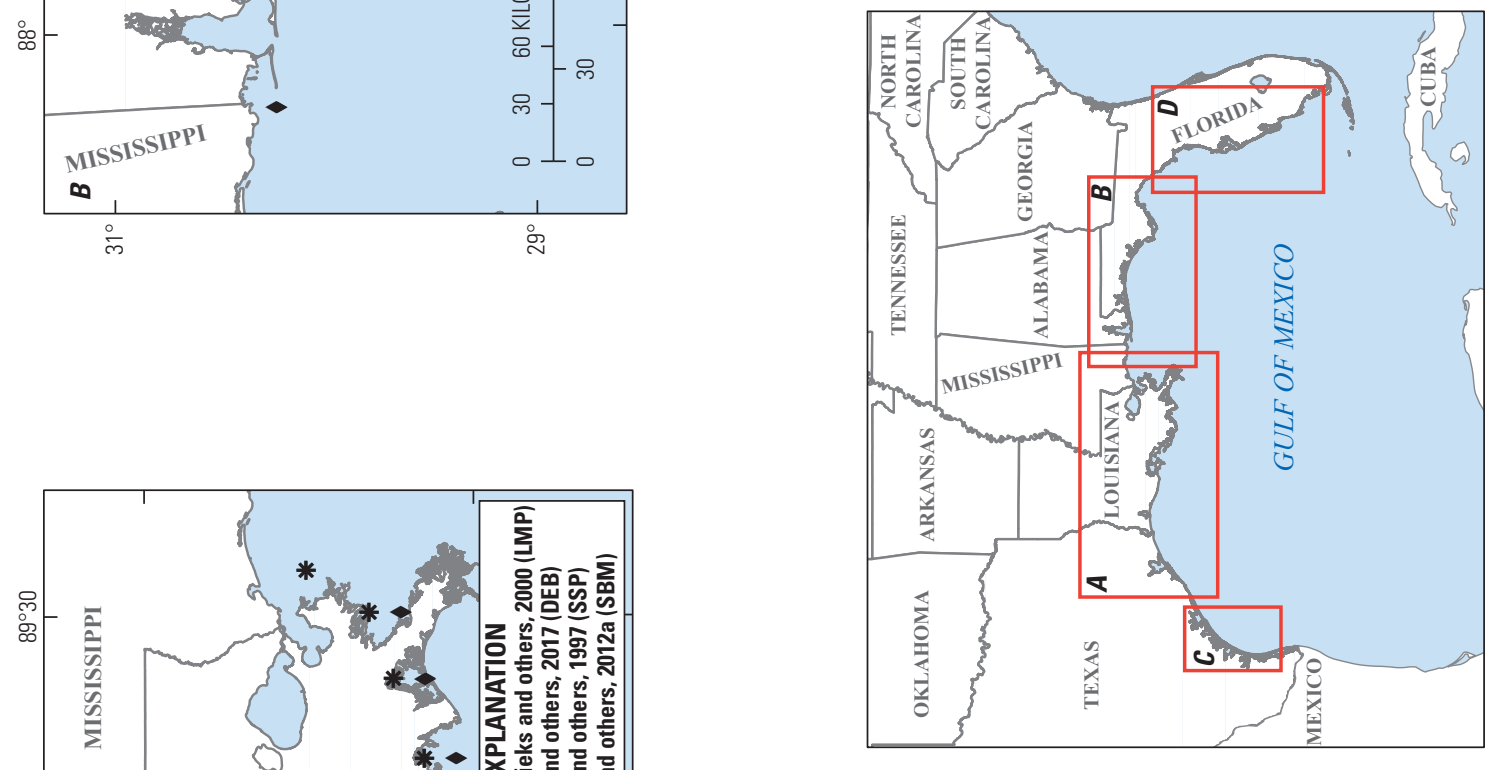

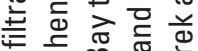

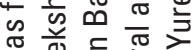

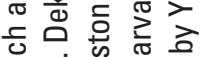

के

is

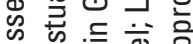

i ब क

은 잊 응 잉

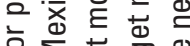

is $\sum_{4}$

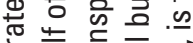

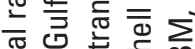

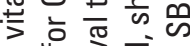

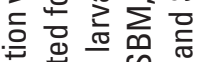

元要严出嵌

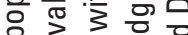

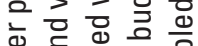

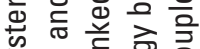

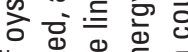

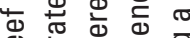

凹

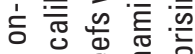

원

至

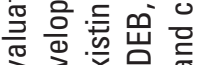

ฮ ख ख

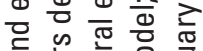

ऽ

뫃

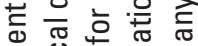

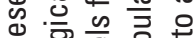

흐응응응

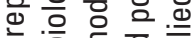

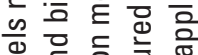

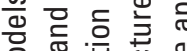

$\sum \frac{0}{\pi} \frac{\pi}{\pi}$

를 홍요

녕 d

此 $\frac{N}{\omega}$ 응

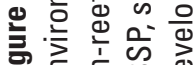
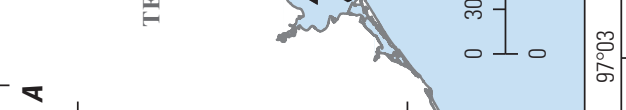

0
2
$x$

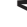

요 
determine the sustainability of individual reefs. Model outputs include changes in oyster density, shell density, and reef mass, with the goal of providing guidance to limit negative shell balances, particularly on harvested reefs. Further exploration of this topic would be useful in ensuring restoration or harvest reefs are sustainable through natural and anthropogenic induced variation.

Yurek and others (2021) developed an individual-based model (IBM) of oyster reef mechanics that simulates oyster reef-building dynamics. The model tracks the life cycles of individual oysters (somatic tissue, gonad, and shell), the half-lives of the shell valves, and the accumulation of shell matter to simulate the development and persistence of a three-dimensional reef. This model was run on a daily time step over a 22-year period. Individual and reef dynamics responded to salinity, temperature, food availability, predators, and burial. The integrated model includes the oyster population (growth, reproduction, and mortality) and substrate dynamics (accumulation and degradation), which combine to determine reef morphology and structure. This approach integrates on-reef DEB with a shell budget model (SBM) approach, presenting a modeling approach that incorporates both substrate persistence and growth with oyster dynamics on-reef, lacking only a larval transport component.

Robust and flexible on-reef models that estimate oyster growth, survival, and reproduction remain necessary tools for informing the site selection of broodstock reefs. The DEB and IBM reef modeling approaches provide a key component necessary to inform planning but have different data requirements, and both could have a substrate component integrated within them to include reef persistence. The mechanistic, bioenergetics approach is highly flexible, being adaptable to different conditions and populations as demonstrated by Lavaud and others (2021), and it can be integrated into reef or population level models (that is, Yurek and others, 2021). The size-structured reef population approach provides predictive outcomes to inform planning and management of oyster broodstock reefs where long-term field sampling data existincluding oyster density, growth, and survival-for initial setup, calibration, and validation. This modeling approach has been adapted, calibrated, and published for three Gulf of Mexico estuaries to date (table 3.1, fig. 12). Although the size-structured population models rely on significant, local, field-collected data on oyster densities, growth, and survival for model setup calibration and validation, the previous modeling studies have shown such models are capable of capturing existing oyster reef production and predicting shifts of more productive regions within the estuary toward oyster restoration (for example, Dekshenieks and others, 2000; Wang and others, 2008, 2017).

\section{Summary-}

- On-reef oyster growth, mortality, and reproduction modeling uses oyster vital rates and processes to predict individual on-reef oyster or reef trajectories through time.
- Two on-reef model frameworks have been calibrated and validated for Gulf of Mexico estuaries and are described as (1) a mechanistic, bioenergetics approach, and (2) a size-structured reef population approach.

- The on-reef modeling approach provides predictive outcomes that can be scaled to individual oyster, population, or reef levels, and used to inform planning and management of oyster reefs. Integration of an SBM into metapopulation or on-reef models will provide critical information about the potential persistence of individual reef patches through time.

- Validation and calibration rely on local field-collected data on oyster densities, growth, survival, and recruitment; the previous modeling studies have shown on-reef model capabilities in identifying existing oyster reef production and predicting other productive regions within the estuary for oyster restoration.

\section{Approach 4: Metapopulation Approach (Coupled Larval Transport and On-Reef Oyster Models)}

An oyster metapopulation model for the full life cycle simulates both on-reef oyster growth, mortality, and reproduction, as well as oyster larval transport and settlement among reefs, with key environmental variables to drive the modeled oyster processes (fig. 8) over space and time. Several models related to on-reef oyster population processes and larval oyster transport have been developed for Gulf of Mexico and the Atlantic coast (table 3.1), but only two examples exist in which the larval transport and on-reef models have been linked to simulate the full oyster life cycle across a network of reefs (see Dekshenieks and others, 2000, for the Gulf of Mexico, and Puckett and Eggleston, 2016, for Pamlico Sound, North Carolina). A considerable amount of effort and data are required to construct, test, calibrate, and validate a full life cycle metapopulation approach using spatiotemporal inputs from monitoring data and (or) hydrodynamic and water-quality models. However, a metapopulation model could be useful in assessing reef connectivity across an estuary, and beyond, which is critical to understanding recruitment and reef persistence through time. Dekshenieks and others' (2000) oyster metapopulation model evaluated how water-quality changes affected the oyster population structure in Galveston Bay, Texas. Hourly temperature, monthly food availability, seston concentrations, and salinity drove daily on-reef oyster growth, mortality, and reproduction in the size-structured reef population model setup for reef sites overlain on a $3 \mathrm{D}$ circulation model grid (Powell and others, 1992; Hofmann and others, 1992). Reef recruitment was driven by the modeled impacts of current velocity, temperature, salinity, food availability, and oyster reef area on oyster larval transport, growth, and mortality, and settlement to existing reef areas. A 5-year reference simulation using mean environmental conditions was run, and the coupled models generated spatial 
maps of total oyster density, adult density, number of eggs spawned, number of recruits, and larval survivorship. This reference output was then used to compare simulations with varying freshwater inflows, including impacts on changing temperature, and food.

Puckett and Eggleston (2016) used an alternative approach to represent the oyster metapopulation of Pamlico Sound, North Carolina, by creating size-structured matrix population models from oyster growth and survival data collected among the network of reefs. These data, along with the larval transport model from Puckett and others (2014), were coupled to link recruitment among the reefs. The resulting metapopulation model was used to (1) explore questions relevant to restoration, including the relative importance of larval connectivity or on-reef processes in determining source-sink dynamics, and (2) evaluate alternative reef network design concepts for restoration planning.

\section{Summary-}

- A metapopulation approach accounts for both larval transport and settlement of spat on the reefs, as well as on-reef oyster processes such as growth, mortality, and reproduction.

- Dekshenieks and others (2000) provides an example for Galveston Bay, Tex. Methods for calibrating and validating the oyster components are described for some of the other larval transport and on-reef modeling studies.

- The metapopulation model, once calibrated and validated for specific regions or estuaries, could help direct oyster monitoring data needs, assess oyster reef health, inform adaptive management of reef networks, and predict potential changes to oyster broodstock reefs over time and space based on future environmental scenarios and management planning objectives.

- The effort and data required to construct, test, calibrate, and validate a full life cycle metapopulation approach are extensive and require a large research commitment.

\section{Other Approaches}

Other models that do not easily fit in the four categories identified provide one or more of the following: (1) relevant information to support some of the above-referenced models, (2) outcomes related to disease, or (3) food web effects of oysters or reefs (table 3.1).

Livingston and others (2000) represents one of the first attempts to explain oyster population data based on spatially resolved daily environmental conditions generated by a coupled estuarine circulation model. Livingston and others (2000) used monthly and biweekly oyster data collected over multiple stations in Apalachicola Bay and coupled the oyster data to outputs generated from a 3D POM (Princeton Ocean Model) of the system. Field data for oyster larval concentrations, spat settlement, total oyster densities, and biomass estimates at reef sites were statistically evaluated, with significant relationships described using multiple regression models to show the relation to bottom salinity, temperature, currents, water depth, turbidity, and DO concentrations generated by the POM. Oyster studies have continued to explore the relationships and variation in oyster larval spat settlement, oyster densities and biomass, and oyster growth and mortality using spatiotemporal environmental data layers created in GIS from field data and existing hydrodynamicwater-quality or estuarine circulation models of the systems (for example, Lowe and others, 2017). The Livingston and others (2000) methodology is included here, as it has been continually referenced in oyster HSI development and verification of SI parameters using oyster monitoring data coupled with spatiotemporal environmental conditions.

Hofmann and others (2001) explicitly models parasitism and disease; specifically, MSX (multinucleated sphere X) disease caused by the pathogen Haplosporidium nelsoni in Chesapeake Bay oysters. Hofmann and others (2001) also models the transmission, proliferation, and death rates of the parasite and the oyster. Environmental data, including temperature, salinity, and food supply, were used to run the model for 10 years in the Chesapeake Bay to examine how changes in environmental conditions affected the prevalence and intensities of the MSX disease in oysters. This explicit host-parasite model specifically modeled ingestion, respiration, and mortality of oysters to identify how the transmission and spread of MSX may vary by environmental conditions; however, oyster mortality and disease prevalence in relation to salinity and temperature are already accounted for within some of the on-reef oyster population models and even within some of the HSIs.

Fulford and others (2010) provides an example of modeling oyster populations within a food web context. Specifically, Fulford and others (2010) modeled the daily biomass for 23 prey, competitor, and predator groups centered around and including oyster larvae and oyster reef biomass pools within a food web modeling platform called TroSIM. Daily larval and reef oyster consumption and growth were driven by three size classes of phytoplankton concentrations and exposed to different simulated wateryear conditions in order to examine the cascading effects of oyster consumption on the estuarine food web. Additional nutrient reduction scenarios and oyster reef stocking scenarios were run to evaluate the effects on oyster biomass and the food web. In a similar vein, several estuarine food web models with oysters as component biomass pools have been developed for the Gulf of Mexico (for example, de Mutsert and others, 2017; DSLLC, 2016). This modeling approach does not necessarily cover the modeled oyster processes in the same level of detail as the larval transport and on-reef oyster growth models do, and modeling the oyster populations within a food web context adds additional uncertainty and complexity without long-term field data to support calibration and validation for each added biomass pool or population interacting with oysters. 


\section{Discussion}

Multiple modeling approaches exist for informing site selection of broodstock or sanctuary oyster reefs, often with trade-offs (table 2). However, the development, calibration, and validation of a single modeling platform to be used for each selected approach presents the most efficient, transferable, and useful tool to use throughout the Gulf of Mexico. The development of this single modeling platform would involve using standardized input variables, governing equations, and assumptions for oyster processes and outputs for standardized calibration and validation procedures that could be applied within each estuary. The differences among estuary applications would require substituting only estuary-specific environmental data, and calibrating and validating with local oyster data. Based on available work to date, the two approaches most likely to be useful include (1) development of a general geospatial HSI modeling framework that could be applied consistently across estuaries, and (2) a coupled larval/on-reef full oyster cycle metapopulation model requiring only estuary-specific calibration and hydrodynamic models. This ultimately would require substantial upfront investment but would yield enormous benefits, providing a spatially diversified model platform that can handle new and more extreme conditions and fulfill the critical steps needed to move from single-reef to reef network management.

A general geospatial HSI modeling framework could be developed using a widely available geospatial analysis and mapping program (that is, Esri ArcGIS), similar to what Beseres Pollack and others (2012) and Swannack and others (2014) describe, for consistent evaluation and planning of oyster resources across Gulf of Mexico estuaries. In fact, the Beseres Pollack and others (2012) approach has already been applied to Gulf estuaries in coastal Texas (Reisinger and others, 2020). Expert stakeholder groups involved in oyster restoration across the Gulf of Mexico could compile an all-inclusive list of potentially important environmental, biological, and logistical inputs that drive oyster distribution and mortality patterns in the estuaries and coastal regions through workshops, as described in Puckett and others (2018) and Theuerkauf and others (2019). The full suite of HSI input variables, with suitability functions and relationships (SIs borrowed from previous studies, could be programmed within a general GIS framework for use by the agencies tasked with oyster restoration planning, management, and monitoring by State. Geospatial HSIs could be set up using any input variables and SI equations from the full list determined from expert stakeholder meetings, and station data from local field monitoring studies can be spatially interpolated in a GIS (for example, Beseres Pollack and others, 2012), and by using outputs generated from existing 2D and 3D numerical models of estuarine water quality and circulation (for example, the EFDC and WASP used in Linhoss and others [2016] and SFWMM used in Barnes and others [2007]).

A metapopulation approach simulating the full oyster life cycle via coupled larval transport (with growth, survival, and behavior) and on-reef population models could additionally be developed for detailed understanding and testing, and for comparison of reefs across Gulf of Mexico estuaries. This approach is detailed and complex, with both the larval transport modeling and on-reef population model components requiring their own development, testing, and verification, and calibration and (or) validation data; however, the approach previously has been used by Dekshenieks and others (2000) by means of size-structured on-reef population modeling. Wang and others $(2008,2017)$ applied the on-reef modeling component approach to Apalachicola Bay, Florida, and Breton Sound, Louisiana; therefore, this size-structured modeling approach for on-reef populations has been validated and tested in multiple Gulf of Mexico estuaries. Alternatively, the DEB approach has been calibrated and validated for multiple estuaries in the Gulf of Mexico, such that this on-reef approach to modeling oyster growth and reproduction provides a similarly flexible option to the size-structured model for coupling with larval transport models to evaluate the full oyster life cycle by estuary. The DEB model provides a mechanistic (processbased) approach, based on physiological and metabolic processes common to all living species, that can be easily adapted to both genetic variation in natural populations and variation in local environmental conditions (Augustine and Kooijman, 2019), and may be easily adapted across the wide range of conditions in Gulf of Mexico estuaries.

These geospatial HSI and the mechanistic metapopulation approaches each have advantages and disadvantages, address different oyster processes and questions, and have different data requirements. Both provide valuable support for oyster restoration but may differ in their ability to address specific questions related to oyster restoration. The geospatial HSI approach, while currently more widely used and accessible, requires more development of larval suitability and larval input and output components to inform reef connectivity (that is, see Milroy and others, 2020a, b, c). This is not an easy issue to resolve and is only mentioned here for consideration; further work would be needed to determine whether or not larval suitability warrants additional study and if so, how to include it within the geospatial suitability modeling framework. Coupled larval and on-reef models (DEB, or size structured with SBM, as in Soniat and others [2012a, 2014] or Yurek and others [2021]) provide more detailed and responsive — but less accessible - approaches, as they are often built on a daily time scale and can be easily adjusted to incorporate new research and understanding. These models are more data-intensive and require some expertise to run and apply to broodstock and sanctuary reef site selection, and to use in evaluation (for example, in a predictive capacity) under monitoring and adaptive management. If planners decided to concentrate on developing two independent platforms for both the Geospatial Suitability Index modeling and metapopulation modeling, then considering larval suitability over space and time may not be necessary, as the larval transport component within the coupled metapopulation approach will address these factors. 


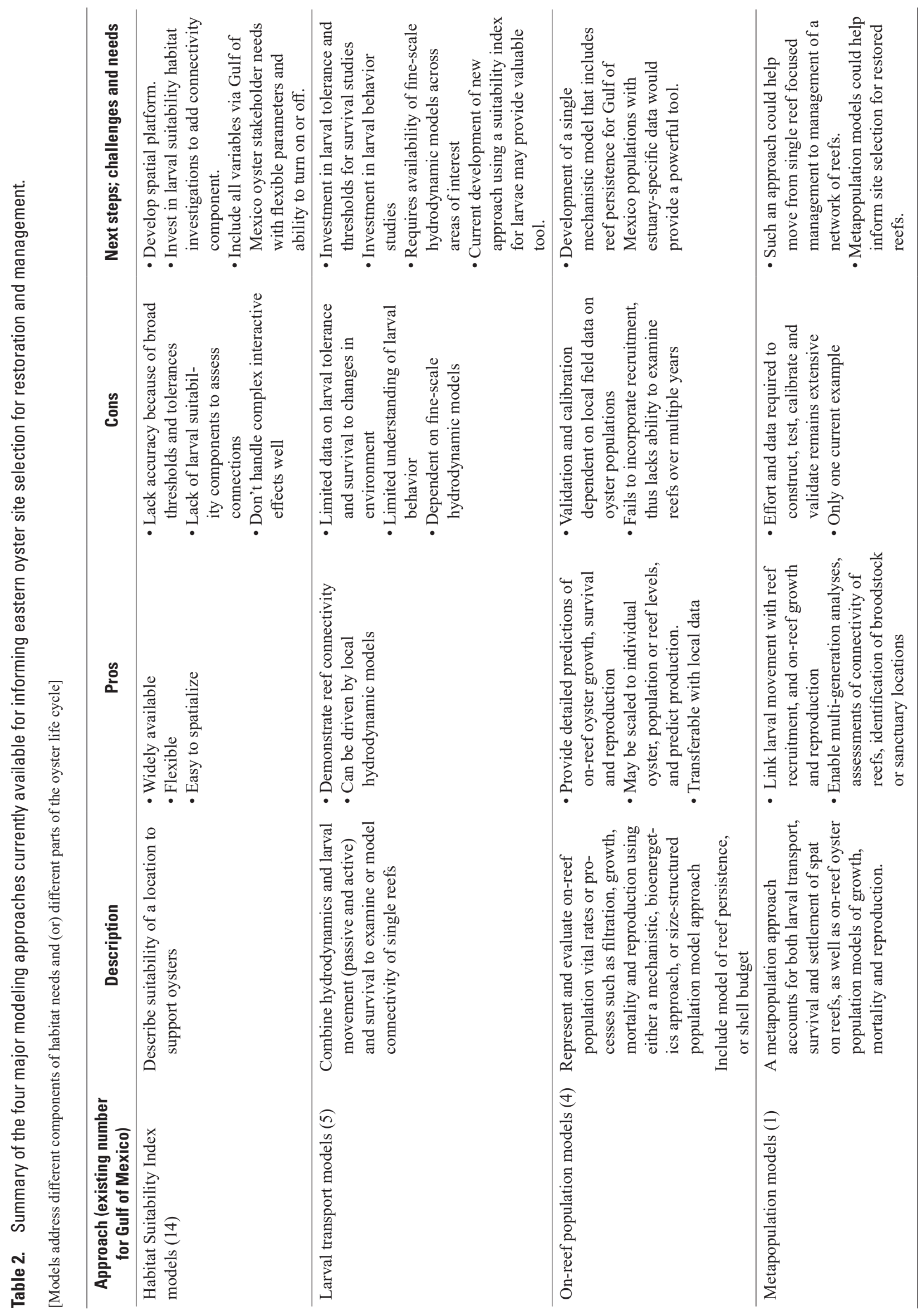


Independent development and testing, calibration, and validation of both of these approaches could provide an opportunity for ensemble modeling in which planners and managers have two modeling tools. Outputs can be (1) compared and used to inform each other, (2) used together to better understand and communicate how oysters and reef sustainability respond to changes, and (3) used to identify key research needs related to our understanding of oyster life cycles (that is, growth, mortality, and reproduction), reef sustainability, and reef connectivity. Further, modeling results can be compared to determine which approach better addresses specific planning questions (that is, broodstock reef site selection, estuarine-level resource response, and so forth), scenario predictions (that is, changing environmental conditions, impact of reef development in specific locations, and so forth), or contributes to model improvements including those that reflect an improved understanding of oyster metapopulations.

Ultimately, the development of a single modeling platform would provide a flexible tool applicable across all Gulf of Mexico oyster-supporting estuaries. Using a single modeling platform (one source code with user interface and [or] input files to run the model, with code changes made by a single development team and released as model versions) for development, testing, and calibration/validation has several advantages. Oyster restoration scientists and managers would not only be able to examine different scenario outcomes within a single estuary, but could also have comparable modeled results to assess potential outcomes across estuaries and regions that are not confounded by varying approaches, assumptions, or user judgement. Many parts of some existing models (table 3.1) can be incorporated into the new model. Selection of the modeling approaches and programming platforms to use for model development, testing, and application needs further attention and may benefit from involvement by scientists and managers with this expertise in the Gulf of Mexico (see table 3.1).

As management goals increasingly call for restoration of oyster reef networks, moving from managing single reefs in isolation to managing connected reefs, these approaches would provide critical information. However, getting there would require substantial up-front investment in data, research, and model development, but would yield enormous benefits by providing a spatially diversified modeling platform for each selected modeling approach that can handle new and more extreme conditions, and fulfill the critical steps needed to move from single-reef to reef network management.

\section{References Cited}

Aguilar Marshall, D., La Peyre, M.K., Guillou, G., Beseres Pollack, J., and Lebreton, B. (in press) Freshwater inflow and responses from estuaries across an extensive climatic gradient-An assessment of northwestern Gulf of Mexico estuaries based on stable isotopes: Limnology and Oceanography.
Arnold, W.S., Meyers, S.D., Geiger, S.P., Luther, M.E., Narvàez, D., Frischer, M.E., and Hofmann, E., 2017, Applying a coupled biophysical model to predict larval dispersal and source/sink relationships in a depleted metapopulation of the eastern oyster Crassostrea virginica: Journal of Shellfish Research, v. 36, no. 1, p. 101-118, accessed July 2020 at https://doi.org/10.2983/036.036.0112.

Atwood, R.L., and Grizzle, R.E., 2020, Eastern oyster recruitment patterns on and near natural reefs-Implications for the design of oyster reef restoration projects: Journal of Shellfish Research, v. 39, no. 2, p. 283-289, accessed July 2020 at https://doi.org/10.2983/035.039.0209.

Augustine, S., and Kooijman, S.A.L.M., 2019, A new phase in DEB research: Journal of Sea Research, v. 143, p. 1-7, accessed December 2020 at https://doi.org/10.1016/j. seares.2018.06.003.

Bales, J., Tomlinson, S.A., and Tillis, G., 2006, Flow and salt transport in the Suwannee River Estuary, Florida, 1999-2000 - Analysis of data and three-dimensional simulations: U.S. Geological Survey Professional Paper 1656-B, 66 p.

Bargu, S., Justic, D., White, J.R., Lane, R., Day, J., Paerl, H.W., and Raynie, R., 2019, Mississippi River diversions and phytoplankton dynamics in deltaic Gulf of Mexico estuaries-A review: Estuarine, Coastal and Shelf Science, v. 221, p. 39-52, accessed July 2020 at https://doi.org/10.1016/j.ecss.2019.02.020.

Barnes, T.K., Volety, A.K., Chartier, K., Mazzotti, F.J., and Pearlstine, L., 2007, A Habitat Suitability Index model for the eastern oyster (Crassostrea virginica), a tool for restoration of the Caloosahatchee Estuary, Florida: Journal of Shellfish Research, v. 26, no. 4, p. 949-959, accessed July 2020 at https://doi.org/10.2983/07308000(2007)26[949:AHSIMF]2.0.CO;2.

Battista, T.A., 1999, Habitat Suitability Index for the eastern oyster Crassostrea virginica, in the Chesapeake Bay-A geographic information system approach: College Park, Md., University of Maryland at College Park, Master's thesis, $111 \mathrm{p}$.

Baustian, M.M., Meselhe, E., Jung, H., Sadid, K., DukeSylvester, S.M., Visser, J.M., Allison, M.A., Moss, L.C., Ramatchandirane, C., Sebastiaan van Maren, D., Jeuken, M., and Bargu, S., 2018, Development of an integrated biophysical model to represent morphological and ecological processes in a changing deltaic and coastal ecosystem: Environmental Modelling \& Software, v. 109, p. 402-419, accessed July 2020 at https://doi.org/10.1016/j.envsoft.2018.05.019.

Bayne, B., ed., 2017, Biology of oysters 1st ed.: London, Academic Press, 860 p. [Volume 41 of Developments in Aquaculture and Fisheries Science book series]. 
Beck, M.W., Brumbaugh, R.D., Airoldi, L., Carranza, A., Coen, L.D., Crawford, C., Defeo, O., Edgar, G.J., Hancock, B., Kay, M.C., Lenihan, H.S., Luckenbach, M.W., Toropova, C.L., Zhang, G., and Guo, X., 2011, Oyster reefs at risk and recommendations for conservation, restoration, and management: Bioscience, v. 61, no. 2, p. 107-116, accessed July 2020 at https://doi.org/10.1525/bio.2011.61.2.5.

Bell, G.L., Abraham, D.D., and Clifton, N.D., 2018, Hydrodynamics in the Morganza Floodway and Atchafalaya Basin report 2-Phase 2 (final report): U.S. Army Corps of Engineers, Mississippi River Geomorphology \& Potamology Program Report no. 26, prepared by the U.S. Army Engineer Research and Development Center, Coastal Hydraulics Laboratory, $134 \mathrm{p}$.

Beseres Pollack, J., Cleveland, A., Palmer, T.A., Reisinger, A.S., and Montagna, P.A., 2012, A Restoration Suitability Index model for the eastern oyster (Crassostrea virginica) in the Mission-Aransas Estuary, TX, USA: PLoS ONE, v. 7, no. 7, article e40839, 11 p., accessed July 2020 at https://doi.org/10.1371/journal.pone.0040839.

Biasutti, M., Sobel, A.H., Camargo, S.J., and Creyts, T.T., 2012, Projected changes in the physical climate of the Gulf Coast and Caribbean: Climatic Change, v. 112, no. 3-4, p. 819-845.

Blumberg, A., and Mellor, G.L., 1987, A description of a threedimensional coastal ocean circulation model, in Heaps, N.S., ed., Three dimensional coastal ocean models: Washington, D.C., American Geophysical Union, p. 1-16.

Bourlès, Y., Alunno-Bruscia, M., Pouvreau, S., Tollu, G., Leguay, D., Arnaud, C., Goulletquer, P., and Kooijman, S.A.L.M., 2009, Modelling growth and reproduction of the Pacific oyster Crassostrea gigas-Advances in the oyster-DEB model through application to a coastal pond: Journal of Sea Research, v. 62, no. 2-3, p. 62-71, accessed July 2020 at https://doi.org/10.1016/j.seares.2009.03.002.

Brooks, R.P., 1997, Improving Habitat Suitability Index models: Wildlife Society Bulletin, v. 25, p. 163-167.

Brown, G.L., McAlpin, J.N., Pevey, K.C., Luong, P.V., Price, C.R., and Kleiss, B.A., 2019, Mississippi River hydrodynamic and delta management study_-Delta management modeling (final report): U.S Army Corps of Engineers (USACE), Coastal and Hydraulics Laboratory, AdH/SEDLIB multidimensional model validation and scenario analysis report ERDC/CHL TR-19-2, prepared by the U.S. Army Engineer Research and Development Center, USACE New Orleans District, and USACE Mississippi Valley Division, 172 p.

Brown, S., Couvillion, B., Conzelmann, C., de Mutsert, K., Fischbach, J., Hunnicutt, C., McKelvy, M., Quibodeaux, P., Roberts, H., Rodrigue, M., Schindler, J., Suir, K., Thomson, G., Visser, J., and White, E., 2017, Modeling components and overview, appendix C, chap. 3, of 2017 Coastal master plan (final version): Baton Rouge, La., Coastal Protection and Restoration Authority, $72 \mathrm{p}$.
Bunya, S., Dietrich, J.C., Westerink, J.J., Ebersole, B.A., Smith, J.M., Atkinson, J.H., Jensen, R., Resio, D.T., Luettich, R.A., Dawson, C., Cardone, V.J., Cox, A.T., Powell, M.D., Westerink, H.J., and Roberts, H.J., 2010, A highresolution coupled riverine flow, tide, wind, wind wave, and storm surge model for southern Louisiana and MississippiPart 1, model development and validation: Monthly Weather Review, v. 138, no. 2, p. 345-377, accessed September 2020 at https://doi.org/10.1175/2009MWR2906.1.

Burford, M.O., Scarpa, J., Cook, B.J., and Hare, M.P., 2014, Local adaptation of a marine invertebrate with a high dispersal potential_-Evidence from a reciprocal transplant experiment of the eastern oyster Crassostrea virginica: Marine Ecology Progress Series, v. 505, p. 161-175, accessed July 2020 at https://doi.org/10.3354/meps 10796.

Buzzelli, C., Doering, P.H., Wan, Y., Sun, D., and Fugate, D., 2014, Modeling ecosystem processes with variable freshwater inflow to the Caloosahatchee River Estuary, southwest Florida-1. Model development: Estuarine, Coastal and Shelf Science, v. 151, p. 256-271, accessed September 2020 at https://doi.org/10.1016/j.ecss.2014.08.028.

Buzzelli, C., Gorman, P., Doering, P.H., Chen, Z., and Wan, Y., 2015, The application of oyster and seagrass models to evaluate alternative inflow scenarios related to Everglades restoration: Ecological Modelling, v. 297, p. 154-170, accessed September 2020 at https://doi.org/10.1016/j.ecolmodel.2014.10.029.

Cake, E.W., 1983, Habitat Suitability Index models - Gulf of Mexico American oyster: U.S. Department of Interior, Fish and Wildlife Service, FWS/OBS-82/10.57, 37 p.

Camacho, R.A., Martin, J., Watson, B., Paul, M.J., Zheng, L., and Stribling, J.B., 2015, Modeling the factors controlling phytoplankton in the St. Louis Bay Estuary, Mississippi and evaluating estuarine responses to nutrient load modifications: Journal of Environmental Engineering, v. 141, no. 3, p. 04014067, accessed September 2020 at https://doi. org/10.1061/(ASCE)EE.1943-7870.0000892.

Cambazoglu, K., and Wiggert, J., 2020, Physical model of the Mississippi Sound and Bight from 2015-05-14 to 2015-07-14 sustainability and restoration of oyster reef habitat in Mississippi Sound-A larval transport and recruitment approach: Gulf of Mexico Research Initiative Information and Data Cooperative (GRIIDC), Harte Research Institute, Texas A\&M University-Corpus Christi, accessed May 10, 2021, at https://doi.org/10.7266/QXZVP60A.

Cambazoglu, K., Wiggert, J., and Pan, C., 2020a, Physical model of the Mississippi Sound and Bight from 2016-05-14 to 2016-07-15 sustainability and restoration of oyster reef habitat in Mississippi Sound-A larval transport and recruitment approach: Gulf of Mexico Research Initiative Information and Data Cooperative (GRIIDC), Harte Research Institute, Texas A\&M University-Corpus Christi, accessed May 10, 2021, at https://doi.org/10.7266/CGFJ6TY4. 
Cambazoglu, K., Wiggert, J., and Pan, C., 2020b, Physical model of the Mississippi Sound and Bight from 2017-05-14 to 2017-10-26 sustainability and restoration of oyster reef habitat in Mississippi Sound-A larval transport and recruitment approach: Gulf of Mexico Research Initiative Information and Data Cooperative (GRIIDC), Harte Research Institute, Texas A\&M University-Corpus Christi, accessed May 10, 2021, at https://doi.org/10.7266/FYMFTNPP.

Cambazoglu, K., Wiggert, J., and Pan, C., 2020c, Modeled drifter simulations for oyster larvae trajectory in Mississippi Sound and Bight from 2015-05-14 to 2015-07-15 sustainability and restoration of oyster reef habitat in Mississippi Sound-A larval transport and recruitment approach: Gulf of Mexico Research Initiative Information and Data Cooperative (GRIIDC), Harte Research Institute, Texas A\&M University-Corpus Christi, accessed May 10, 2021, at https://doi.org/10.7266/ZKM29VT2.

Cambazoglu, K., Wiggert, J., and Pan, C., 2020d, Modeled drifter simulations for oyster larvae trajectory in Mississippi Sound and Bight from 2017-05-14 to 2017-10-26: Gulf of Mexico Research Initiative Information and Data Cooperative (GRIIDC), Harte Research Institute, Texas A\&M University-Corpus Christi, accessed May 10, 2021, at https://doi.org/10.7266/2SP9XTRT.

Carriker, M.R., 1951, Ecological observations on the distribution of oyster larvae in New Jersey estuaries: Ecological Monographs, v. 21, no. 1, p. 19-38.

Casas, S.M., Lavaud, R., La Peyre, M.K., Comeau, L.A., Filgueira, R., and La Peyre, J.F., 2018, Quantifying salinity and season effects on eastern oyster clearance and oxygen consumption rates: Marine Biology, v. 165, no. 5, p. 90, accessed July 2020 at https://doi.org/10.1007/s00227-018-3351-x.

Castagna, M., and Chanley, P., 1973, Salinity tolerance of some marine bivalves from inshore and estuarine environments in Virginia waters on the western mid-Atlantic coast: Malacologia, v. 12, p. 47-96.

Chen, J., Weisberg, R.H., Liu, Y., Zheng, L., and Zhu, J., 2019, On the momentum balance of Tampa Bay: Journal of Geophysical Research. Oceans, v. 124, no. 7, p. 4492-4510, accessed December 2020 at https://doi. org/10.1029/2018JC014890.

Choi, K.-S., Lewis, D.H., Powell, E.N., and Ray, S.M., 1993, Quantitative measurement of reproductive output in the American oyster, Crassostrea virginica (Gmelin), using an enzyme-linked immunosorbent assay (ELISA): Aquaculture and Fisheries Management, v. 24, no. 3, p. 299-322.

Choi, K.-S., Powell, E.N., Lewis, D.H., and Ray, S.M., 1994, Instantaneous reproductive effort in female American oysters, Crassostrea virginica, measured by a new immunoprecipitation assay: The Biological Bulletin, v. 186, no. 1, p. 41-61.
Cobell, Z., Sable, S., and Rose, K., 2020, Calcasieu Ship Channel Salinity Control Measures Project-Larval transport modeling: Coastal Protection and Restoration Authority, prepared by the Water Institute of the Gulf, Baton Rouge, La., 106 p.

Colden, A.M., and Lipcius, R.N., 2015, Lethal and sublethal effects of sediment burial on the eastern oyster Crassostrea virginica: Marine Ecology Progress Series, v. 527, p. 105-117, accessed December 2020 at https://doi. org/10.3354/meps11244.

Comeau, L.A., 2014, Spring awakening temperature and survival of sediment-covered eastern oysters Crassostrea virginica-Amsterdam: Aquaculture (Amsterdam, Netherlands), v. 430, p. 188-194, accessed December 2020 at https://doi.org/10.1016/j.aquaculture.2014.04.009.

Craig, A., Powell, E.N., Fay, R.R., and Brooks, J.M., 1989, Distribution of Perkinsus marinus in Gulf Coast oyster populations: Estuaries, v. 12, no. 2, p. 82-91, accessed July 2020 at https://doi.org/10.2307/1351499.

Cyriac, R., Dietrich, J.C., Blain, C.A., Dawson, C.N., Dresback, K.M., Fathi, A., Bilskie, M.V., Graber, H.C., Hagen, S.C., and Kolar, R.L., 2020, Wind and tide effects on the Choctawhatchee Bay plume and implications for surface transport at Destin Inlet: Regional Studies in Marine Science, v. 35, article 101131, accessed July 2020 at https://doi.org/10.1016/j.rsma.2020.101131.

Dame, R.F., Spurrier, J.D., and Wolaver, T.G., 1989, Carbon, nitrogen and phosphorous processing by an oyster reef: Marine Ecology Progress Series, v. 54, p. 249-256.

Dame, R.F., Bushek, D., Allen, D., Edwards, D., Gregory, L., Lewitus, A.J., Crawford, S., Koepfler, E., and Middelburg, E.A., 2000, The experimental analysis of tidal creeks dominated by oyster reefs-The premanipulation year: Journal of Shellfish Research, v. 19, no. 1, p. 361-369.

Deepwater Horizon Natural Resource Damage Assessment Trustees [DWH NRDA], 2017, Deepwater Horizon oil spill natural resource damage assessment-Strategic framework for oyster restoration activities: Accessed May 2021 at https://www.gulfspillrestoration.noaa.gov/restoration-planning/gulf-plan.

Dekshenieks, M.M., Hofmann, E.E., and Powell, E.N., 1993, Environmental effects on the growth and development of eastern oyster, Crassostrea virginica (Gmelin, 1791), larvae-A modeling study: Journal of Shellfish Research, v. 12 , p. $241-254$.

Dekshenieks, M.M., Hofmann, E.E., Klinck, J.M., and Powell, E.N., 1996, Modeling the vertical distribution of oyster larvae in response to environmental conditions: Marine Ecology Progress Series, v. 136, p. 97-110. 
Dekshenieks, M.M., Hofmann, E.E., Klinck, J.M., and Powell, E.N., 1997, A modeling study of the effects of size- and depth-dependent predation on larval survival: Journal of Plankton Research, v. 19, no. 11, p. 1583-1598.

Dekshenieks, M.M., Hofmann, E.E., Klinck, J.M., and Powell, E.N., 2000, Quantifying the effects of environmental change on an oyster population-A modeling study: Estuaries, v. 23 , no. 5, p. 593-610, accessed July 2020 at https://doi. org/10.2307/1352887.

de Mutsert, K., Lewis, K., Milroy, S., Buszowski, J., and Steenbeek, J., 2017, Using ecosystem modeling to evaluate trade-offs in coastal management-Effects of large-scale river diversions on fish and fisheries: Ecological Modelling, v. 360, p. 14-26, accessed September 2020 at https://doi. org/10.1016/j.ecolmodel.2017.06.029.

Denapolis, T.M.V., 2018, Legacy habitat suitability of eastern oysters (Crassostrea virginica) in Louisiana: A prelude to Mississippi River Delta freshwater diversions: New Orleans, La., University of New Orleans, M.S. thesis, [Theses and Dissertations 2560], 130 p., accessed July 2020 at https://scholarworks.uno.edu/td/2560.

Du, J., Park, K., Shen, J., Zhang, Y.J., Yu, X., Ye, F., Wang, Z., and Rabalais, N.N., 2019, A hydrodynamic model for Galveston Bay and the shelf in the northern Gulf of Mexico: Ocean Science, v. 15, no. 4, p. 951-966, accessed July 2020 at https://doi.org/10.5194/os-15-951-2019.

Dynamic Solutions, L.L.C., [DSLLC], 2007, Hydrologic, hydrodynamic and water quality model, Perdido Bay, Florida: Tallahassee, Fla., Division of Water Resource Management, Watershed Assessment Section, Florida Department of Environmental Protection, prepared by Dynamic Solutions, LLC, $231 \mathrm{p}$.

Dynamic Solutions, L.L.C., [DSLLC], 2008, Caloosahatchee River Basin TMDL model support- Section 5, site specific model selection, preparation, verification, calibration, and validation: Tallahassee, Fla., Division of Water Resource Management, Watershed Assessment Section, Florida Department of Environmental Protection, prepared by Dynamic Solutions, LLC, 71 p.

Dynamic Solutions, L.L.C., [DSLLC], 2009, Indian River Lagoon TMDL model support- Section 9, EFDC water quality model set-up, verification, calibration, and validation: Tallahassee, Fla., Division of Water Resource Management, Watershed Assessment Section, Florida Department of Environmental Protection, prepared by Dynamic Solutions, LLC, $62 \mathrm{p}$.

Dynamic Solutions, L.L.C., [DSLLC], 2016, Development of the CASM for evaluation of fish community impacts for the Mississippi River Delta management study-Revised report: Baton Rouge, La., Louisiana Coastal Protection and Restoration Authority, GEC Inc., Project No. 2503-13-42, prepared by Dynamic Solutions, LLC, March 2016, 102 p.
Eierman, L.E., and Hare, M.P., 2016, Reef-specific patterns of gene expression plasticity in eastern oysters (Crassostrea virginica): American Genetic Association, v. 107, no. 1, p. 90-100, accessed September 2020 at https://doi. org/10.1093/jhered/esv057.

Filgueira, R., Guyondet, T., Comeau, L.A., and Grant, J., 2014, A fully-spatial ecosystem-DEB model of oyster (Crassostrea virginica) carrying capacity in the Richibucto Estuary, Eastern Canada: Journal of Marine Systems, v. 136, p. 42-54, accessed September 2020 at https://doi. org/10.1016/j.jmarsys.2014.03.015.

Ford, S.E., Chintala, M.M., and Bushek, D., 2002, Comparison of in vitro-cultured and wild-type Perkinsus marinus. I. Pathogen virulence: Diseases of Aquatic Organisms, v. 51, p. 187-201, accessed July 2020 at https://doi.org/10.3354/ dao051187.

Fulford, R.S., Breitburg, D.L., Luckenbach, M., and Newell, R.I.E., 2010, Evaluating ecosystem response to oyster restoration and nutrient load reduction with a multispecies bioenergetics model: Ecological Applications, v. 20, no. 4, p. 915-934, accessed September 2020 at https://doi. org/10.1890/08-1796.1.

Galtsoff, P.S., 1964, The American oyster Crassostrea virginica Gmelin: U.S. Fish and Wildlife Service Fishery Bulletin, v. $64,480 \mathrm{p}$.

Garton, D., and Stickle, W.B., 1980, Effects of salinity and temperature on the predation rate of Thais haemastoma on Crassostrea virginica spat: The Biological Bulletin, v. 158, no. 1, p. 49-57.

George, L.M., De Santiago, K., Palmer, T.A., and Beseres Pollack, J., 2014, Oyster reef restoration-Effect of alternative substrates on oyster recruitment and nekton habitat use: Journal of Coastal Conservation, v. 19, no. 1, p. 13-22, accessed September 2020 at https://doi.org/10.1007/s11852014-0351-y.

Grabowski, J.H., Brumbaugh, R.D., Conrad, R.F., Keeler, A.G., Opaluch, J.J., Peterson, C.H., Piehler, M.F., Powers, S.P., and Smyth, A.R., 2012, Valuation of ecosystem services provided by oyster reefs: Bioscience, v. 62 , no. 10 , p. 900-909, accessed September 2020 at https://doi. org/10.1525/bio.2012.62.10.10.

Graham, P.M., Palmer, T.A., and Beseres Pollack, J., 2017, Oyster reef restoration - Substrate suitability may depend on specific restoration goals: Restoration Ecology, v. 25, no. 3, p. 459-470, accessed September 2020 at https://doi. org/10.1111/rec.12449.

Grizzle, R.E., Greene, J.K., and Coen, L.D., 2008, Seston removal by natural and constructed intertidal eastern oyster (Crassostrea virginica) reefs-A comparison with previous laboratory studies, and the value of in situ methods: Estuaries and Coasts, v. 31, no. 6, p. 1208-1220, accessed September 2020 at https://doi.org/10.1007/s12237-008-9098-8. 
Grizzle, R.E., Langan, R., and Huntting Howell, W., 1992, Growth responses of suspension-feeding bivalve molluscs to changes in water flow-Differences between siphonate and nonsiphonate taxa: Journal of Experimental Marine Biology and Ecology, v. 162, no. 2, p. 213-228, accessed September 2020 at https://doi.org/10.1016/0022-0981(92)90202-L.

Gulf of Mexico Alliance Water-Quality Team, 2013, White paper on Gulf of Mexico water-quality monitoring - Providing water-quality information to support informed resource management and public knowledge: Tallahassee, Fla., Gulf of Mexico Alliance, variously paged, accessed July 2021 at http://www.gulfofmexicoalliance.org/files/projects/files/ goma_gulf_monitoring_white_paper.pdf.

Guthrie, C.G., Matsumoto, J., and Lu, Q., 2010, TxBLEND Model Calibration and Validation for the Guadalupe and Mission-Aransas Estuaries (July 2010): Austin, Tex., Texas Water Development Board, 46 p.

Guthrie, C.G., Schoenbaechler, C., Matsumoto, J., and Lu, Q., 2012, TxBLEND Model Calibration and Validation for the Trinity-San Jacinto Estuary (March 22, 2012): Austin, Tex., Texas Water Development Board, 56 p.

Guyondet, T., Sonier, R., and Comeau, L.A., 2013, A spatially explicit seston depletion index to optimize shellfish culture: Aquaculture Environment Interactions, v. 4, no. 2, p. 175-186, accessed September 2020 at https://doi. org/10.3354/aei00083.

Haase, A.T., Eggleston, D.B., Luettich, R.A., Weaver, R.J., and Puckett, B.J., 2012, Estuarine circulation and predicted oyster larval dispersal among a network of reserves: Estuarine, Coastal and Shelf Science, v. 101, p. 33-43, accessed September 2020 at https://doi.org/10.1016/j. ecss.2012.02.011.

Haidvogel, D.B., Arango, H.G., Hedström, K., Beckmann, A., Malanotte-Rizzoli, P., and Shchepetkin, A.F., 2000, Model evaluation experiments in the North Atlantic Basin-Simulations in nonlinear terrain-following coordinates: Dynamics of Atmospheres and Oceans, v. 32, no. 3-4, p. 239-281, accessed September 2020 at https://doi.org/10.1016/ S0377-0265(00)00049-X.

Haines, E.B., and Montague, C.L., 1979, Food sources of estuarine invertebrates analyzed using $13 \mathrm{C} / 12 \mathrm{C}$ ratios: Ecology, v. 60, no. 1, p. 48-56, accessed September 2020 at https://doi.org/10.2307/1936467.

Haven, D.S., and Morales-Alamo, R., 1970, Filtration of particles from suspension by the American oyster Crassostrea virginica: The Biological Bulletin, v. 139, no. 2, p. 248-264, accessed July 2020 at https://doi.org/10.2307/1540081.
Hayes, P.F., and Menzel, R.W., 1981, The reproductive cycle of early setting Crassostrea virginica (Gmelin) in the northern Gulf of Mexico, and its implications for population recruitment: The Biological Bulletin, v. 160, no. 1, p. 80-88, accessed September 2020 at https://doi. org/10.2307/1540902.

Hijuelos, A.C., Sable, S.E., O'Connell, A.M., and Geaghan, J.P., 2016, 2017 Coastal Master Plan-C3-12, eastern oyster, Crassostrea virginica, Habitat Suitability Index model, version II: Baton Rouge, La., Coastal Protection and Restoration Authority, $23 \mathrm{p}$.

Hofmann, E.E., Klinck, J.M., Powell, E.N., Boyles, S., and Ellis, M., 1994, Modeling oyster populations II-Adult size and reproductive effort: Journal of Shellfish Research, v. 13, no. 1 , p. $165-182$.

Hofmann, E.E., Ford, S., Powell, E., and Klinck, J., 2001, Modeling studies of the effect of climate variability on MSX disease in eastern oyster (Crassostrea virginica) populations: Hydrobiologia, v. 460, no. 1/3, p. 195-212, accessed September 2020 at https://doi. org/10.1023/A:1013159329598.

Hofmann, E.E., Powell, E.N., Klinck, J.M., and Wilson, E.Z., 1992, Modeling oyster populations III-Critical feeding periods, growth and reproduction: Journal of Shellfish Research, v. 11, p. 399-416.

Hu, K., Chen, Q., and Wang, H., 2015, A numerical study of vegetation impact on reducing storm surge by wetlands in a semi-enclosed estuary: Coastal Engineering, v. 95, p. 66-76, accessed September 2020 at https://doi.org/10.1016/j. coastaleng.2014.09.008.

Huang, H., 2011, Finite Volume Community Ocean Model (FVCOM) 3D hydrodynamic model comparison-Final report: Austin, Tex., Texas Water Development Board, prepared by author under contract, $42 \mathrm{p}$.

Huang, W., 2010, Hydrodynamic modeling and ecohydrological analysis of river inflow effects on Apalachicola Bay, Florida, USA: Estuarine, Coastal and Shelf Science, v. 86, no. 3, p. 526-534, accessed September 2020 at https://doi. org/10.1016/j.ecss.2009.07.032.

Huguenard, K.D., Bogucki, D.J., Ortiz-Suslow, D.G., Laxague, N.J.M., MacMahan, J.H., Ozgokmen, T.M., Haus, B.K., Reniers, A.J.H.M., Hargrove, J., Soloviev, A.V., and Graber, H., 2016, On the nature of the frontal zone of the Choctawhatchee Bay plume in the Gulf of Mexico: Journal of Geophysical Research. Oceans, v. 121, no. 2, p. 1322-1345, accessed September 2020 at https://doi. org/10.1002/2015JC010988. 
Jorgensen, C., 1966, Biology of suspension feeding: Oxford, Pergamon Press, 357 p.

Keim, B.D., Fontenot, R.F., Tebaldi, C., and Shankman, D., 2011, Hydroclimatology of the U.S. Gulf Coast under global climate change scenarios: Physical Geography, v. 32, no. 6, p. 561-582, accessed September 2020 at https://doi. org/10.2747/0272-3646.32.6.561.

Kellogg, M.L., Cornwell, J.C., Owens, M.C., and Paynter, K.T., 2013, Denitrification and nutrient assimilation on a restored oyster reef: Marine Ecology Progress Series, v. 480, p. 1-9, accessed September 2020 at https://doi. org/10.3354/meps 10331 .

Kennedy, V.S., 1996, Biology of larvae and spat, in Kennedy, V.S., Newell, R.I.E., and Eble, A.F., eds., The eastern oyster Crassostrea virginica: College Park, Md., Maryland Sea Grant College, p. 371-411.

Kennedy, V.S., Breitburg, D.L., Christman, M.C., Luckenbach, M.W., Paynter, K., Kramer, J., Sellner, K.G., DewBaxter, J., Keller, C., and Mann, R., 2011, Lessons learned from efforts to restore oyster populations in Maryland and Virginia, 1990 to 2007: Journal of Shellfish Research, v. 30, no. 3, p. 719-731, accessed July 2020 at https://doi. org/10.2983/035.030.0312.

Kim, C.K., 2009, A modeling study of oyster larval transport in Mobile Bay and eastern Mississippi Sound: Mobile, Ala., University of South Alabama, Ph.D. dissertation, 186 p.

Kim, C.K., and Park, K., 2012, A modeling study of water and salt exchange for a micro-tidal, stratified northern Gulf of Mexico estuary: Journal of Marine Systems, v. 96-97, p. 103-115, accessed September 2020 at https://doi. org/10.1016/j.jmarsys.2012.02.008.

Kim, C.K., Park, K., and Powers, S.P., 2013, Establishing restoration strategy of eastern oyster via a coupled biophysical transport model: Restoration Ecology, v. 21, no. 3, p. 353-362, accessed September 2020 at https://doi. org/10.1111/j.1526-100X.2012.00897.x.

Kim, C.K., Park, K., Powers, S.P., Graham, W.M., and Bayha, K.M., 2010, Oyster larval transport in coastal AlabamaDominance of physical transport over biological behavior in a shallow estuary: Journal of Geophysical Research, v. 115, article C10019, p. 1-16, accessed July 2020 at https://doi. org/10.1029/2010JC006115.

King, I.P., 1985, Strategies for finite element modeling of three-dimensional hydrodynamic systems: Advances in Water Resources, v. 8, no. 2, p. 69-76, accessed September 2020 at https://doi.org/10.1016/0309-1708(85)90002-8.
Klinck, J.M., Hofmann, E.E., Powell, E.N., and Dekshenieks, M., 2002, Impact of channelization on oyster production-A hydrodynamic-oyster population model for Galveston Bay, Texas: Environmental Modeling and Assessment, v. 7, no. 4, p. 273-289, https://link. springer.com/content/pdf/10.1023/A:1020954502355.pdf, accessed June 2021.

Klinck, J.M., Powell, E.N., Hofmann, E.E., Wilson, E.A., and Ray, S.M., 1992, Modeling oyster populations - the effect of density and food supply on production: Proceedings of Advancement of Marine Technology Conference, 5, p. 85-105.

Langdon, C.J., and Newell, R.I.E., 1996, Digestion and nutrition in larvae and adults, in Kennedy, V.S., Newell, R.I.E., and Eble, A.F., eds., The eastern oyster Crassostrea virginica: College Park, Md., Maryland Sea Grant, p. 231-270.

La Peyre, M.K., Aguilar Marshall, D., Miller, L.S., and Humphries, A.T., 2019, Oyster reefs in northern Gulf of Mexico estuaries harbor diverse fish and decapod crustacean assemblages - A meta-synthesis: Frontiers in Marine Science, v. 6, no. 666, 13 p., accessed July 2020 at https://doi.org/10.3389/fmars.2019.00666.

La Peyre, M.K., Bernasconi, S.B., Lavaud, R., Casas, S.M., and La Peyre, J.F., 2020, Eastern oyster clearance and respiration rates in response to acute and chronic exposure to suspended sediment loads: Journal of Sea Research, v. 157, article 101831, 7 p., accessed July 2020 at https://doi. org/10.1016/j.seares.2019.101831.

La Peyre, M.K., Eberline, B.S., Soniat, T.M., and La Peyre, J.F., 2013, Differences in extreme low salinity timing and duration differentially affect eastern oyster (Crassostrea virginica) size class growth and mortality in Breton Sound, LA: Estuarine, Coastal and Shelf Science, v. 135, p. 146-157, accessed July 2020 at https://doi.org/10.1016/j. ecss.2013.10.001.

La Peyre, M.K., Geaghan, J., Decossas, G., and La Peyre, J.F., 2016, Analysis of environmental factors influencing salinity patterns, oyster growth, and mortality in lower Breton Sound Estuary, Louisiana, using 20 years of data: Journal of Coastal Research, v. 319, p. 519-530, accessed July 2020 at https://doi.org/10.2112/JCOASTRES-D-15-00146.1.

La Peyre, M.K., Humphries, A.T., Casas, S.M., and La Peyre, J.F., 2014, Temporal variation in development of ecosystem services from oyster reef restoration: Ecological Engineering, v. 63, p. 34-44, accessed July 2020 at https://doi. org/10.1016/j.ecoleng.2013.12.001. 
La Peyre, M.K., Nickens, A.D., Volety, A.K., Tolley, G.S., and La Peyre, J.F., 2003, Environmental significance of freshets in reducing Perkinsus marinus infection in eastern oysters Crassostrea virginica -Potential management applications: Marine Ecology Progress Series, v. 248, p. 165-176.

La Peyre, M.K., Serra, K., Joyner, T.A., and Humphries, A., 2015, Assessing shoreline exposure and oyster habitat suitability maximizes potential success for sustainable shoreline protection using restored oyster reefs: PeerJ, v. 3, article e1317, accessed July 2020 at https://doi.org/10.7717/peerj.1317.

Lavaud, R., La Peyre, M.K., Casas, S.M., Bacher, C., and La Peyre, J.F., 2017, Integrating the effects of salinity on the physiology of the eastern oyster, Crassostrea virginica, in the northern Gulf of Mexico through a dynamic energy budget model: Ecological Modelling, v. 363, p. 221-233, accessed July 2020 at https://doi.org/10.1016/j.ecolmodel.2017.09.003.

Lavaud, R., La Peyre, M.K., Justic, D., and La Peyre, J.L., 2021, Dynamic Energy Budget modelling to predict Eastern oyster growth, reproduction, and mortality under river management and climate change scenarios: Estuarine, Coastal and Shelf Science, v. 251, article 107188, accessed May 11, 2021, at https://www.sciencedirect.com/science/ article/pii/S027277142100024X?via\%3Dihub/.

Legare, B., and Mace, C., 2017, Mapping and classifying eastern oyster (Crassostrea virginica) habitat in Copano Bay, Texas, by coupling acoustic technologies: Journal of Coastal Research, v. 332, p. 286-294, accessed September 2020 at https://doi.org/10.2112/JCOASTRESD-15-00205.1.

Lenihan, H.S., and Peterson, C.H., 1998, How habitat degradation through fishery disturbance enhances impacts of hypoxia on oyster reefs: Ecological Applications, v. 8, no. 1, p. 128-140, accessed September 2020 at https://doi. org/10.1890/1051-0761(1998)008[0128:HHDTFD]2.0.CO;2.

Leonhardt, J.M., Casas, S., Supan, J.E., and La Peyre, J.F., 2017, Stock assessment for eastern oyster seed production and field grow-out in Louisiana: Amsterdam, Netherlands, Aquaculture, v. 466, p. 9-19, accessed September 2020 at https://doi.org/10.1016/j.aquaculture.2016.09.034.

Li, M., Zhong, L., and Boicourt, W.C., 2005, Simulations of Chesapeake Bay estuary-Sensitivity to turbulence mixing parameterizations and comparison with observations: Journal of Geophysical Research, v. 110, article C12004, 22 p., accessed May 2021 at https://doi. org/10.1029/2004JC002585.
Lin, N., Lane, P., Emanuel, K., Sullivan, R.M., and Donnelly, J.P., 2014, Heightened hurricane surge risk in northwest Florida revealed from climatological-hydrodynamic modeling and paleorecord reconstruction: Journal of Geophysical Research, D, Atmospheres, v. 119, no. 14, p. 8606-8623, accessed September 2020 at https://doi. org/10.1002/2014JD021584.

Lindquist, D.C., Sable, S.E., D’Acunto, L., Hijuelos, A.C., Johnson, E.I., Langlois, S.R.M., Michel, N.L., Nakashima, L., O'Connell, A.M., Percy, K., and Robinson, E.M., 2021, 2023 Coastal Master Plan-Habitat Suitability Index model improvements (final draft): Baton Rouge, La., Coastal Protection and Restoration Authority, 194 p., accessed May 10, 2021, at https://coastal.la.gov/wp-content/ uploads/2021/04/HSI-Model-Improvements_April2021.pdf.

Linhoss, A.C., Camacho, R., and Ashby, S., 2016, Oyster habitat suitability in the northern Gulf of Mexico: Journal of Shellfish Research, v. 35, no. 4, p. 841-849, accessed September 2020 at https://doi.org/10.2983/035.035.0412.

Lipcius, R.N., Burke, R.P., McCulloch, D.N., Schreiber, S.J., Schulte, D.M., Seitz, R.D., and Shen, J., 2015, Overcoming restoration paradigms - Value of the historical record and metapopulation dynamics in native oyster restoration: Frontiers in Marine Science, v. 2, p. 65-73, accessed June 2020 at https://doi.org/10.3389/fmars.2015.00065.

Lipcius, R.N., Eggleston, D.B., Schreiber, S.J., Seitz, R.D., Shen, J., Sisson, M., Stockhausen, W.T., and Wang, H.V., 2008, Importance of metapopulation connectivity to restocking and restoration of marine species: Reviews in Fisheries Science, v. 16, no. 1-3, p. 101-110, accessed June 2020 at https://doi.org/10.1080/10641260701812574.

Livingston, R.J., Lewis, F.G., Woodsum, G.C., Niu, X.F., Galperin, B., Huang, W., Christensen, J.D., Monaco, M.E., Battista, T.A., Klein, C.J., Howell, R.L., IV, and Ray, G.L., 2000, Modelling oyster population response to variation in freshwater input: Estuarine, Coastal and Shelf Science, v. 50, no. 5, p. 655-672, accessed June 2020 at https://doi. org/10.1006/ecss.1999.0597.

Loosanoff, V.L., 1965, The American or eastern oyster: U.S. Department of the Interior, Fish and Wildlife Service, Bureau of Commercial Fisheries, Circular 205, 36 p.

Lough, R.G., 1975, A re-evaluation of the combined effects of temperature and salinity on survival and growth of bivalve larvae using response surface techniques: Fish Bulletin, v. 73 , p. 86-94. 
Louisiana Department of Wildlife and Fisheries [LDWF], 2018, Oyster stock assessment report: Baton Rouge, La., Louisiana Department of Wildlife and Fisheries, Oyster data report series no. $24,68 \mathrm{p}$.

Lowe, M.R., Sehlinger, T., Soniat, T.M., and La Peyre, M.K., 2017, Interactive effects of water temperature and salinity on growth and mortality of eastern oysters, Crassostrea virginica - A meta-analysis using 40 years of monitoring data: Journal of Shellfish Research, v. 36, no. 3, p. 683-697.

Luettich, R.A., Westerrink, J.J., and Scheffner, N.W., 1992, ADCIRC: An advanced three-dimensional circulation model for shelves, coasts, and estuaries-Report 1, theory and methodology of ADCIRC-2DDI and ADCIRC-3DL: Washington D.C., U.S. Army Corps of Engineers, Technical Report DRP-92-6, 137 p.

Luettich, R.A., Jr., Carr, S.D., Reynolds-Fleming, J.V., Fulcher, C.W., and McNinch, J.E., 2002, Semi-diurnal seiching in a shallow, micro-tidal lagoonal estuary: Continental Shelf Research, v. 22, no. 11-13, p. 1669-1681, accessed June 2020 at https://doi.org/10.1016/S02784343(02)00031-6.

Lundberg, C.J., Lane, R.R., and Day, J.W., Jr., 2014, Spatial and temporal variations in nutrients and water quality parameters in the Mississippi River-influenced Breton Sound estuary: Journal of Coastal Research, v. 30, no. 2, p. 328-336, accessed June 2020 at https://doi.org/10.2112/ JCOASTRES-D-12-00015.1.

MacKenzie, C.L., Jr., 1981, Biotic potential and environmental resistance in the American oyster (Crassostrea virginica) in Long Island Sound-Amsterdam: Aquaculture (Amsterdam, Netherlands), v. 22, p. 229-268, accessed June 2020 at https://doi.org/10.1016/0044-8486(81)90151-4.

Mann, R., and Powell, E.E., 2007, Why oyster restoration goals in the Chesapeake Bay are not and probably cannot be achieved: Journal of Shellfish Research, v. 26, no. 4, p. 905-917, accessed June 2020 at https://doi. org/10.2983/0730-8000(2007)26[905:WORGIT]2.0.CO;2.

Mann, R., Southworth, M., Carnegie, R.B., and Crockett, R.K., 2014, Temporal variation in fecundity and spawning in the eastern oyster, Crassostrea virginica, in the Piankatank River, Virginia: Journal of Shellfish Research, v. 33, no. 1, p. 167-176, accessed June 2020 at https://doi. org/10.2983/035.033.0116.
Marshall, D.A., Casas, S.M., Walton, W.C., Rikard, F.S., Palmer, T.A., Breaux, N., La Peyre, M.K., Pollack, J.B., Kelly, M., and La Peyre, J.F. (in press) Divergence in salinity tolerance of northern Gulf of Mexico oysters under field and laboratory exposure: Conservation Physiology.

Marshall, D.A., Moore, S.C., Sutor, M., La Peyre, J.F., and La Peyre, M.K., 2020, Using reproductive potential to assess oyster population sustainability: Restoration Ecology, v. 28, no. 6, p. 1621-1632, accessed May 11, 2021, at https://doi.org/10.1111/rec.13225.

Matsumoto, J., Guthrie, C.G., Crockett, D., and McEwen, T., 2014, TxBLEND model extension and salinity validation for the Sabine-Neches Estuary-Extending simulations through 2013: Austin, Tex., Texas Water Development Board, 24 p.

Menzel, R.W., Hulings, N.C., and Hathaway, R.R., 1958, Oyster abundance in Apalachicola Bay, Florida, in relation to biotic associations influenced by salinity and other factors: Gulf Research Reports, v. 2, p. 73-96.

Metaxas, A., and Saunders, M., 2009, Quantifying the "bio-" components in biophysical models of larval transport in marine benthic invertebrates - Advances and pitfalls: The Biological Bulletin, v. 216, no. 3, p. 257-272, accessed June 2020 at https://doi.org/10.1086/BBLv216n3p257.

Milroy, S., Cambazoglu, K., Wiggert, J., Pan, C., 2020a, Habitat Suitability Index (HSI) model results for oyster larvae trajectory and condition, COAWST_2017_Grp06_Srf_d02 drifter simulation released from Drum Bay, Louisiana from 201705-19 to 2017-10-26: Gulf of Mexico Research Initiative Information and Data Cooperative (GRIIDC), Harte Research Institute, Texas A\&M University-Corpus Christi, accessed May 11, 2021, at https://doi.org/10.7266/VY9DED3G.

Milroy, S., Cambazoglu, K., Wiggert, J., Pan, C., 2020b, Habitat Suitability Index (HSI) model results for oyster larvae trajectory and condition, COAWST_2017_Grp22_Srf_d01 drifter simulation released from Pass aux Herons, Alabama from 2017-06-04 to 2017-07-08: Gulf of Mexico Research Initiative Information and Data Cooperative (GRIIDC), Harte Research Institute, Texas A\&M University-Corpus Christi, accessed May 11, 2021, at https://doi.org/10.7266/16TX911K.

Milroy, S., Cambazoglu, K., Wiggert, J., Pan, C., 2020c, Habitat Suitability Index (HSI) model results for oyster larvae trajectory and condition, COAWST_2017_Grp16_Srf_d02 drifter simulation released from Biloxi Bay, Mississippi from 201705-29 to 2017-10-02: Gulf of Mexico Research Initiative Information and Data Cooperative (GRIIDC), Harte Research Institute, Texas A\&M University-Corpus Christi, accessed May 11, 2021, at https://doi.org/10.7266/N62BJWTZ. 
Mississippi Department of Environmental Quality [MDEQ], 2015, The Mississippi Oyster Cultch Restoration Project: Mississippi Department of Environmental Quality report, 8 p., accessed March 19, 2021, at https://www.gulfspillrestoration.noaa.gov/wp-content/uploads/MS_PI_OysterCultch_MonitoringPlan_5-2015.pdf.

Mroch, R.M., III, Eggleston, D.B., and Puckett, B.J., 2012, Spatiotemporal variation in oyster fecundity and reproductive output in a network of no-take reserves: Journal of Shellfish Research, v. 31, no. 4, p. 1091-1101, accessed June 2020 at https://doi.org/10.2983/035.031.0420.

Murray, J., Roman, H., and Westerink, J., 2015, Development of oyster larval transport analysis (ADCIRC): Technical memorandum provided to National Oceanic and Atmospheric Administration August 31, 2015, prepared by the authors under contract, $14 \mathrm{p}$.

National Oceanic and Atmospheric Administration [NOAA], 2020, Commercial fisheries statistics - Annual landings: Accessed June 2020 at https://foss.nmfs.noaa.gov/apexfoss/.

Newell, R.I.E., and Jordan, S.J., 1983, Preferential ingestion of organic material by the American oyster Crassostrea virginica: Marine Ecology Progress Series, v. 13, p. 47-53, accessed June 2020 at https://doi.org/10.3354/meps013047.

North, E.W., Schlag, Z., Hood, R.R., Li, M., Zhong, L., Gross, T., and Kennedy, V.S., 2008, Vertical swimming behavior influences the dispersal of simulated oyster larvae in a coupled particle-tracking and hydrodynamic model of Chesapeake Bay: Marine Ecology Progress Series, v. 359, p. 99-115, accessed June 2020 at https://doi.org/10.3354/ meps07317.

Orlando, S.P., Jr., Rozas, L.P., Ward, G.H., and Klein, C.J., 1993, Salinity characteristics of Gulf of Mexico estuaries: Silver Spring, Md., National Oceanic and Atmospheric Administration, Office of Ocean Resources Conservation and Assessment, 209 p.

Pales Espinosa, E., Allam, B., and Ford, S.E., 2008, Particle selection in the ribbed mussel Guekensia demissa and the eastern oyster Crassostrea virginica-Effect of microalgae growth stage: Estuarine, Coastal and Shelf Science, v. 79, no. 1, p. 1-6, accessed June 2020 at https://doi. org/10.1016/j.ecss.2008.02.022.

Park, K., Powers, S.P., Bosarge, G.S., and Jung, H.S., 2014, Plugging the leak-Barrier island restoration following hurricane Katrina enhances larval retention and improves salinity regime for oysters in Mobile Bay, Alabama: Marine Environmental Research, v. 94, p. 48-55, accessed June 2020 at https://doi.org/10.1016/j.marenvres.2013.12.003.
Patillo, M.E., Czapla, T.E., Nelson, D.M., and Monaco, M.E., 1997, Distribution of fishes and invertebrates in Gulf of Mexico estuaries, volume II-Species life history summaries: Silver Spring, Md., National Oceanic and Atmospheric Administration [NOAA], National Ocean Service Strategic Environmental Assessments Division, ELMR Report No. 11, 377 p.

Patterson, H.K., Boettcher, A., and Carmichael, R.H., 2014, Biomarkers of dissolved oxygen stress in oysters-A tool for restoration and management efforts: PLoS ONE, v. 9, no. 8, article e104440, 11 p., accessed July 2020 at https:// doi.org/10.1371/journal.pone.0104440.

Petes, L.E., Brown, A.J., and Knight, C.R., 2012, Impacts of upstream drought and water withdrawals on the health and survival of downstream estuarine oyster populations: Ecology and Evolution, v. 2, no. 7, p. 1712-1724, accessed June 2020 at https://doi.org/10.1002/ece3.291.

Powell, E.N., 2017, What is going on with Perkinsus marinus in the Gulf of Mexico?: Estuaries and Coasts, v. 40, no. 1, p. 105-120, accessed June 2020 at https://doi.org/10.1007/ s12237-016-0128-7.

Powell, E.N., Hofmann, E.E., Klinck, J.M., and Ray, S.M., 1992, Modeling oyster populations-I. A commentary on filtration rate. Is faster always better?: Journal of Shellfish Research, v. 11, p. 387-398.

Powell, E.N., Klinck, J.M., Ashton-Alcox, K.A., Hofmann, E.E., and Morson, J., 2012, The rise and fall of Crassostrea virginica oyster reefs - The role of disease and fishing in their demise and a vignette on their management: Journal of Marine Research, v. 70, no. 2, p. 505-558, accessed June 2020 at https://doi.org/10.1357/002224012802851878.

Powell, E.N., Klinck, J.M., Ashton-Alcox, K.A., and Kraeuter, J.N., 2009, Multiple stable reference points in oyster populations-Implications for reference point-based management: Fish Bulletin, v. 107, p. 133-147.

Powell, E.N., Klinck, J.M., and Hofmann, E.E., 1996, Modeling diseased oyster populations-II. Triggering mechanisms for Perkinsus marinus epizootics: Journal of Shellfish Research, v. 15, p. 141-165.

Powell, E.N., Klinck, J.M., Hofmann, E.E., and Ford, S., 1997, Varying the timing of oyster transplant - Implications for management from simulation studies: Fisheries Oceanography, v. 6, no. 4, p. 213-237, accessed June 2020 at https://doi.org/10.1046/j.1365-2419.1998.00046.x.

Powell, E.N., Klinck, J.M., Hofmann, E.E., WilsonOrmond, E.A., and Ellis, M.S., 1995, Modeling oyster populations - V. Declining phytoplankton stocks and the population dynamics of American oyster (Crassostrea virginica) populations: Fisheries Research, v. 24, no. 3, p. 199-222, accessed May 11, 2021, at https://doi. org/10.1016/0165-7836(95)00370-P. 
Preau, A., Smith, P., and Lopez, J., 2016, Oyster habitat evaluation using hydrocoast salinity data and two approaches to suitability analysis of the Pontchartrain Basin, southeast Louisiana: Lake Pontchartrain Basin Foundation, June 2016, 85 p.

Puckett, B.J., and Eggleston, D.B., 2016, Metapopulation dynamics guide marine reserve design-Importance of connectivity, demographics, and stock enhancement: Ecosphere, v. 7, no. 6, p. e01322, https://esajournals.onlinelibrary.wiley.com/doi/epdf/10.1002/ecs2.1322, accessed June 2021.

Puckett, B.J., Eggleston, D.B., Kerr, P.C., and Luettich, R.A., Jr., 2014, Larval dispersal and population connectivity among a network of marine reserves: Fisheries Oceanography, v. 23, no. 4, p. 342-361, accessed June 2020 at https://doi.org/10.1111/fog.12067.

Puckett, B.J., Theuerkauf, S.J., Eggleston, D.B., Guajardo, R., Hardy, C., Gao, J., and Luettich, R.A., 2018, Integrating larval dispersal, permitting, and logistical factors within a validated Habitat Suitability Index for oyster restoration: Frontiers in Marine Science, v. 5, p. 76-87, accessed June 2020 at https://doi.org/10.3389/fmars.2018.00076.

Quick, J.A., Jr., and Mackin, J.G., 1971, Oyster parasitism by Labyrinthomyxa marina in Florida: Tallahassee, Fla., Florida Department of Natural Resources, Marine Research Laboratory Professional Paper Series no. 13, 55 p.

Reece, J.S., Watson, A., Dalyander, P.S., Edwards, C.K., Geselbracht, L., La Peyre, M.K., Tirpak, B.E., Tirpak, J.M., and Woodrey, M., 2018, A multiscale natural community and species-level vulnerability assessment of the Gulf Coast, USA: PLoS One, v. 13, no. 6, article e0199844, accessed June 2020 at https://doi.org/10.1371/journal. pone.0199844.

Rego, J.L., and Li, C., 2010, Storm surge propagation in Galveston Bay during Hurricane Ike: Journal of Marine Systems, v. 82, no. 4, p. 265-279, accessed June 2020 at https://doi.org/10.1016/j.jmarsys.2010.06.001.

Reisinger, A., Beseres Pollack, J., and Gibeaut, J., 2020, Oyster Reef Restoration Habitat Suitability Index of Texas bays \& estuaries: Coastal and Marine Geospatial Sciences, Gulf of Mexico Research Initiative Information and Data Cooperative (GRIIDC), Harte Research Institute, Texas A\&M University-Corpus Christi online database, accessed May 11, 2021, at https://doi.org/10.7266/n7-htxh-3g51.

Ren, J.S., and Schiel, D.R., 2008, A dynamic energy budget model-Parameterisation and application to the Pacific oyster Crassostrea gigas in New Zealand waters: Journal of Experimental Marine Biology and Ecology, v. 361, no. 1, p. 42-48, accessed June 2020 at https://doi.org/10.1016/j. jembe.2008.04.012.
Riisgård, H.U., 1988, Efficiency of particle retention and filtration rate in 6 species of northeast American bivalves: Marine Ecology Progress Series, v. 45, p. 217-223, accessed June 2020 at https://doi.org/10.3354/meps045217.

Roloff, G.J., and Kernohan, B.J., 1999, Evaluating reliability of Habitat Suitability Index models: Wildlife Society Bulletin, v. 27, p. 973-985.

Rosa, M., Ward, J.E., and Shumway, S.E., 2018, Selective capture and ingestion of particles by suspension-feeding bivalve molluscs - A review: Journal of Shellfish Research, v. 37 , no. 4, p. 727-746, accessed June 2020 at https://doi. org/10.2983/035.037.0405.

Rosa, M., Ward, J.E., Shumway, S.E., Wikfors, G.H., PalesEspinosa, E., and Allam, B., 2013, Effects of particle surface properties on feeding selectivity in the eastern oyster Crassostrea virginica and the blue mussel Mytilus edulis: Journal of Experimental Marine Biology and Ecology, v. 446, p. 320-327, accessed June 2020 at https://doi. org/10.1016/j.jembe.2013.05.011.

Rybovich, M., La Peyre, M.K., Hall, S.G., and La Peyre, J.F., 2016, Increased temperatures combined with lowered salinities differentially impact oyster size class growth and mortality: Journal of Shellfish Research, v. 35, no. 1, p. 101-113, accessed June 2020 at https://doi. org/10.2983/035.035.0112.

Schoenbaechler, C., Guthrie, C.G., Matsumoto, J., and Lu, Q., 2011a, TxBLEND model calibration and validation for the Laguna Madre Estuary, October 27, 2011: Austin, Tex., Texas Water Development Board, 60 p.

Schoenbaechler, C., Guthrie, C.G., Matsumoto, J., Lu, Q., and Negusse, S., 2011b, TxBLEND model calibration and validation for the Lavaca-Colorado Estuary and East Matagorda Bay, February 14, 2011: Austin, Tex., Texas Water Development Board, $72 \mathrm{p}$.

Sheng, Y.P., Yassuda, E.A., and Yang, C., 1995, Modeling the impact of nutrient load reduction and water quality and seagrass in Roberts Bay and Little Sarasota Bay (final report): Sarasota Bay National Estuary Program and Southwest Florida Water Management District, prepared by the authors under contract, $156 \mathrm{p}$.

Shumway, S., 1996, Natural environmental factors, in Kennedy, V.S., Newell, R.I.E., and Eble, A.F., eds., The eastern oyster, Crassostrea virginica: College Park, Md., Maryland Sea Grant, p. 467-513.

Soniat, T.M., 1996, Epizootiology of Perkinsus marinus disease of eastern oysters in the Gulf of Mexico: Journal of Shellfish Research, v. 15, no. 1, p. 35-43.

Soniat, T.M., and Brody, M.S., 1988, Field validation of a Habitat Suitability Index model for the American oyster: Estuaries, v. 11, no. 2, p. 87-95, accessed June 2020 at https://doi.org/10.2307/1351995. 
Soniat, T.M., Conzelmann, C.P., Byrd, J.D., Roszell, D.P., Bridevaux, J.L., Suir, K.J., and Colley, S.B., 2013, Predicting the effects of proposed Mississippi River diversions on oyster habitat quality-Application of an oyster Habitat Suitability Index model: Journal of Shellfish Research, v. 32, no. 3, p. 629-638, accessed June 2020 at https://doi. org/10.2983/035.032.0302.

Soniat, T.M., Cooper, N., Powell, E.N., Klinck, J.M., Abdelguerfi, M., Tu, S., Mann, R., and Banks, P., 2014, Estimating sustainable harvests of eastern oysters, Crassostrea virginica: Journal of Shellfish Research, v. 33, no. 2, p. 381-394, accessed June 2020 at https://doi. org/10.2983/035.033.0207.

Soniat, T.M., Klinck, J.M., Powell, E.N., Cooper, N., Abdelguerfi, M., Hofmann, E.E., Dahal, J., Tu, S., Finigan, J., Eberline, B.S., La Peyre, J.F., La Peyre, M.K., and Qaddoura, F., 2012a, A shell-neutral modeling approach yields sustainable oyster harvest estimates - A retrospective analysis of the Louisiana state primary seed grounds: Journal of Shellfish Research, v. 31, no. 4, p. 1103-1112, accessed July 2020 at https://doi.org/10.2983/035.031.0421.

Soniat, T.M., Klinck, J.M., Powell, E.N., and Hofmann, E.E., $2012 \mathrm{~b}$, Understanding the success and failure of oyster populations-Periodicities of Perkinsus marinus, and oyster recruitment, mortality and size: Journal of Shellfish Research, v. 31, no. 3, p. 635-646, accessed June 2020 at https://doi.org/10.2983/035.031.0307.

Starke, A., Levinton, J.S., and Doall, M., 2011, Restoration of Crassostrea virginica (Gmelin) to the Hudson River, USA-A spatiotemporal modeling approach: Journal of Shellfish Research, v. 30, no. 3, p. 671-684, accessed June 2020 at https://doi.org/10.2983/035.030.0309.

Stickle, W.B., Kapper, M.A., Liu, L.-L., Gnaiger, E., and Wang, S.Y., 1989, Metabolic adaptations of several species of crustaceans and molluscs to hypoxia-Tolerance and microcalorimetric studies: The Biological Bulletin, v. 177 , no. 2, p. 303-312, accessed June 2020 at https://doi.org/10.2307/1541945.

Stith, B.M., Reid, J.P., Langtimm, C.A., Swain, E.D., Doyle, T.J., Slone, D.H., Decker, J.H., and Soderqvist, L.E., 2011, Temperature inverted haloclines provide winter warmwater refugia for manatees in southwest Florida: Estuaries and Coasts, v. 34, no. 1, p. 106-119, accessed June 2020 at https://doi.org/10.1007/s12237-010-9286-1.

Supan, J.E., and Wilson, C.A., 2001, Analyses of gonadal cycling by oyster broodstock, Crassostrea virginica (Gmelin), in Louisiana: Journal of Shellfish Research, v. 20, p. 215-220.
Swain, E., and Decker, J., 2009, Development, testing, and application of a coupled hydrodynamic surface-water/ ground-water model (FTLOADDS) with heat and salinity transport in the Ten-Thousand Islands/Picayune Strand restoration project area, Florida: U.S. Geological Survey Scientific Investigations Report 2009-5146, 83 p., accessed July 2020 at https://pubs.er.usgs.gov/publication/sir20095146.

Swannack, T.M., Reif, M., and Soniat, T.M., 2014, A robust, spatially explicit model for identifying oyster restoration sites - Case studies on the Atlantic and Gulf Coasts: Journal of Shellfish Research, v. 33, no. 2, p. 395-408, accessed June 2020 at https://doi.org/10.2983/035.033.0208.

Tetra Tech, Inc., 2009, St. Andrews Bay hydrodynamic and water quality modeling report: Atlanta, Ga., Environmental Protection Agency [EPA], Region 4, prepared by Tetra Tech, Inc., Atlanta, Ga. 30 p.

Theuerkauf, S.J., Eggleston, D.B., and Puckett, B.J., 2019, Integrating ecosystem services considerations within a GIS-based Habitat Suitability Index for oyster restoration: PLoS ONE, v. 14, no. 1, article e0210936, 25 p., accessed July 2020 at https://doi.org/10.1371/journal.pone.0210936.

Theuerkauf, S.J., and Lipcius, R.N., 2016, Quantitative validation of a Habitat Suitability Index for oyster restoration: Frontiers in Marine Science, v. 3, article 64, 9 p., accessed June 2020 at https://doi.org/10.3389/fmars.2016.00064.

Thomsen, M.S., and McGlathery, K., 2006, Effects of accumulations of sediments and drift algae on recruitment of sessile organisms associated with oyster reefs: Journal of Experimental Marine Biology and Ecology, v. 328, no. 1, p. 22-34, accessed June 2020 at https://doi.org/10.1016/j. jembe.2005.06.016.

U.S. Environmental Protection Agency, [EPA], 2009, Hydrodynamic and water quality modeling report for Peace River and Charlotte Harbor, Florida: Atlanta, Ga., U.S. Environmental Protection Agency, Region 4, 136 p.

U.S. Fish and Wildlife Service [USFWS], 1981, Standards for the development of Habitat Suitability Index models: Washington, D.C., U.S. Fish and Wildlife Service, Division of Ecological Services, ESM 103, 171 p. [Part 103 of Ecological Services Manual]

Varney, R.L., Galindo-Sánchez, C.E., Cruz, P., and Gaffney, P.M., 2009, Population genetics of the eastern oyster Crassostrea virginica (Gmelin, 1791) in the Gulf of Mexico: Journal of Shellfish Research, v. 28, no. 4, p. 855-864, accessed June 2020 at https://doi. org/10.2983/035.028.0415. 
Wang, H., Chen, Q., La Peyre, M.K., Hu, K., and La Peyre, J.F., 2017, Predicting the impacts of Mississippi River diversions and sea-level rise on spatial patterns of eastern oyster growth rate and production: Ecological Modelling, v. 352, p. 40-53, accessed June 2020 at https://doi.org/10.1016/j.ecolmodel.2017.02.028.

Wang, H., Huang, W., Harwell, M.A., Edmiston, L., Johnson, E., Hsieh, P., Milla, K., Christensen, J., Stewart, J., and Liu, X., 2008, Modeling oyster growth rate by coupling oyster population and hydrodynamic models for Apalachicola Bay, Florida, USA: Ecological Modelling, v. 211, no. 1-2, p. 77-89, accessed June 2020 at https://doi.org/10.1016/j. ecolmodel.2007.08.018.

Ward, J.E., and Shumway, S.E., 2004, Separating the grain from the chaff-Particle selection in suspension- and deposit-feeding bivalves: Journal of Experimental Marine Biology and Ecology, v. 300, no. 1-2, p. 83-130, accessed June 2020 at https://doi.org/10.1016/j.jembe.2004.03.002.

Weber, E.D., Helge Vølstad, J., Christman, M.C., Lewis, D., and Dew-Baxter, J.D., 2013, Application of a demographic model for evaluating proposed oyster-restoration actions in Chesapeake Bay: Human and Ecological Risk Assessment, v. 19, no. 5, p. 1187-1203, accessed May 11, 2021, at https://doi.org/10.1080/10807039.2013.767110.

Weissberger, E.J., and Glibert, P.M., 2021, Diet of the eastern oyster, Crassostrea virginica, growing in a eutrophic tributary of the Chesapeake Bay, Maryland, USA: Aquaculture Reports, v. 20, article e100655, accessed June 2020 at https://doi.org/10.1016/j.aqrep.2021.100655.

Wells, H.W., 1961, The fauna of oyster beds, with special reference to the salinity factor: Ecological Monographs, v. 31, no. 3, p. 239-266, accessed June 2020 at https://doi. org/10.2307/1948554.
Widdows, J., Fieth, P., and Worrall, C.M., 1979, Relationships between seston, available food and feeding activity in the common mussel Mytilus edulis: Marine Biology, v. 50, no. 3, p. 195-207, accessed June 2020 at https://doi. org/10.1007/BF00394201.

Wilson-Ormond, E.A., Powell, E.N., and Ray, S.M., 1997, Short-term and small-scale variation in food availability to natural oyster populations - Food, flow and flux-Berlin: Marine Ecology (Berlin), v. 18, no. 1, p. 1-34, accessed June 2020 at https://doi.org/10.1111/j.1439-0485.1997. tb00424.x.

Yurek, S., Eaton, M.J., Lavaud, R., Laney, R.W., DeAngelis, D.L., Pine, W.E., III, La Peyre, M., Martin, J., Frederick, P., Wang, H., Lowe, M.R., Johnson, F., Camp, E.V., and Mordecai, R., 2021, Modeling structural mechanics of oyster reef self-organization including environmental constraints and community interactions: Ecological Modelling, v. 440, p. 109389, accessed May 11, 2021, at https://doi. org/10.1016/j.ecolmodel.2020.109389.

Zhang, Y.J., 2010, Final report of technical support-Intermodel comparison for Corpus Christi Bay testbed: Texas Water Development Board, prepared by Oregon Health \& Science University, 18 p.

Zheng, L., and Weisberg, R.H., 2010, Rookery Bay and Naples Bay circulation simulations-Applications to tides and freshwater inflow regulations: Ecological Modelling, v. 221 , no. 7, p. 986-996, accessed June 2020 at https://doi.org/10.1016/j.ecolmodel.2009.01.024.

zu Ermgassen, P.S.E., Spalding, M.D., Grizzle, R.E., and Brumbaugh, R.D., 2013, Quantifying the loss of a marine ecosystem service-Filtration by the eastern oyster in US estuaries: Estuaries and Coasts, v. 36, no. 1, p. 36-43, accessed June 2020 at https://doi.org/10.1007/s12237-012-9559-y. 


\section{Appendix 1. Discrete Water-Quality Data Sources}

Table 1.1 (available at https://doi.org/10.3133/ofr20211063) is a noncomprehensive list of available sources of water-quality data collected by public institutions for Gulf of Mexico estuaries, including links to data repositories of potentially relevant data. This table provides some sources used to inform models. The websites listed were accessed in December 2020.

\section{Appendix 2. Modeled Water-Quality and Physical Data Sources}

Table 2.1 (available at https://doi.org/10.3133/ofr20211063) is a noncomprehensive list, by estuary, of modeled waterquality and physical data for model inputs. This table provides references for water-quality and physical models used to inform oyster models. All cited references are listed in the References Cited section of the main report.

\section{Appendix 3. Oyster Model Inventory}

Table 3.1 (available at https://doi.org/10.3133/ofr20211063) provides an inventory of models categorized by modeling approach (habitat suitability, larval transport, on-reef, metapopulation, or other). The inventory provides model description and objective, model input variables, sources of input data, modeled processes, output variables, spatial and temporal applicability, and comments on model applicability and accessibility to siting broodstock and sanctuary oyster reefs. The existing models are not listed in alphabetical or chronological order, but rather in the order they are referenced within the report. Habitat Suitability Index (HSI) models are sorted by Gulf of Mexico models first, then Atlantic Ocean models. Models are generally sorted in chronological order, but also by order of studies that were built upon the previous studies. Models are also listed in ascending order of model complexity for some of the approach categories. All cited references are listed in the References Cited section of the main report. 
For more information about this publication, contact Chief, Cooperative Fish and Wildlife Research Units U.S. Geological Survey

MS 303

12201 Sunrise Valley Drive

Reston VA 20192

For additional information, visit https://www1.usgs.gov/coopunits

Publishing support provided by Lafayette Publishing Service Center 
